\title{
FORESTED PLANT ASSOCIATIONS OF THE NORTHERN SUBALPINE REGIONS
}

OF ALBERTA
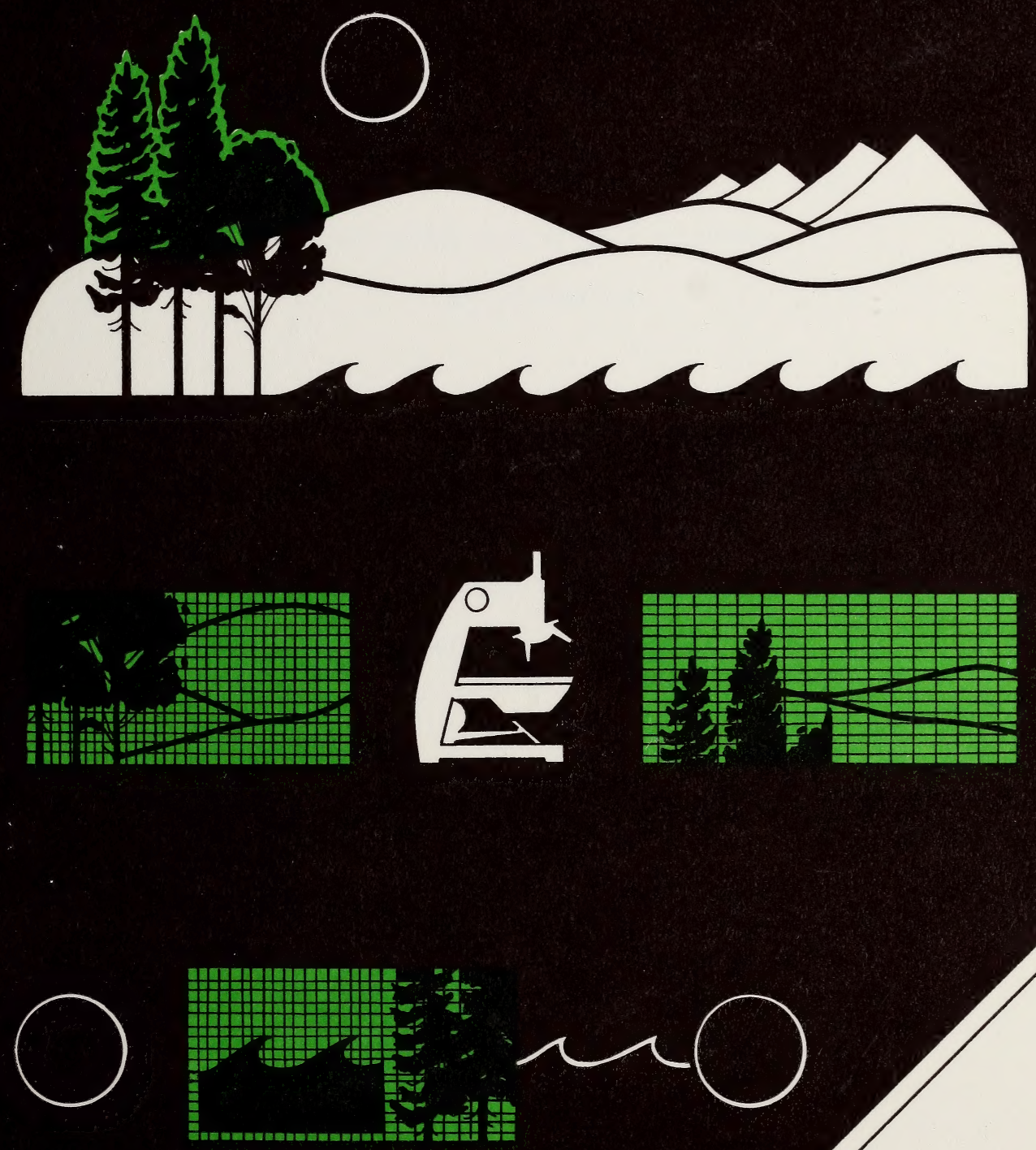


\title{
FORESTED PLANT ASSOCIATIONS OF THE NORTHERN SUBALPINE REGIONS \\ OF ALBERTA
}

\author{
Prepared for \\ DEPARTMENT OF ENERGY AND NATURAL RESOURCES \\ ALBERTA FOREST SERVICE, RESEARCH BRANCH \\ EDMONTON, ALBERTA
}

by

SATORU KOJIMA*

WESTERN ECOLOGICAL SERVICES (B.C.) LTD.

SIDNEY, B.C. V8L 3S 1

1984

* Present address:

Program of Environmental Sciences, College of Liberal Arts, Toyama University 3190 Gofuku, Toyama City, 930 Japan 

ENR Report No. T/64

International Standard Book Number: 0-86499-154-1

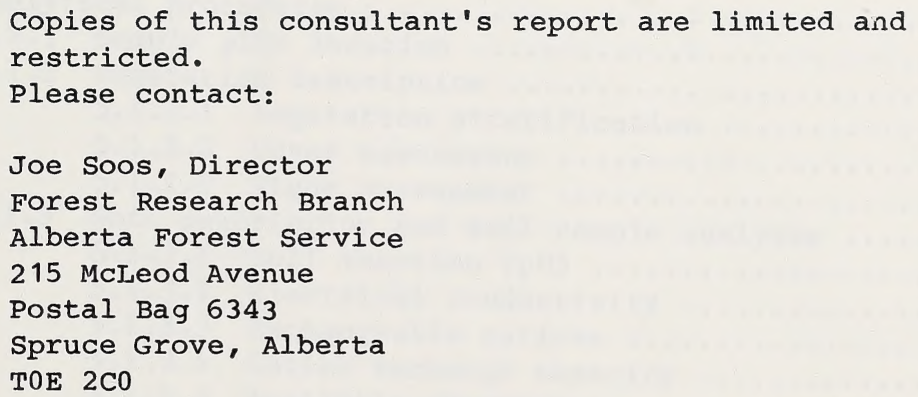

(403) 962-8700 
Digitized by the Internet Archive in 2016

https://archive.org/details/forestedplantass00koji_0 


\title{
TABLE OF CONTENTS
}

\author{
Abstract \\ Acknowledgements \\ List of Figures \\ List of Tables
}

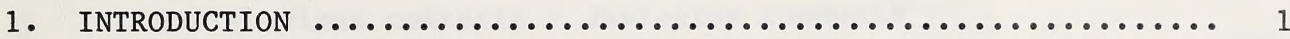

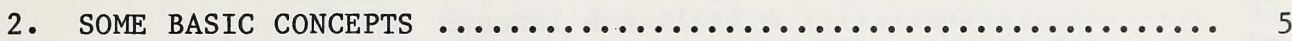

3. THE SUBALPINE ZONE $\ldots \ldots \ldots \ldots \ldots \ldots \ldots \ldots \ldots \ldots \ldots \ldots \ldots \ldots \ldots \ldots \ldots$

4. SUBZONAL DIVISION OF THE SUBALPINE ZONE IN ALBERTA ......... 13

5. METHODS AND PROCEDURES $\ldots \ldots \ldots \ldots \ldots \ldots \ldots \ldots \ldots \ldots \ldots \ldots \ldots \ldots \ldots \ldots \ldots \ldots \ldots \ldots \ldots \ldots \ldots$

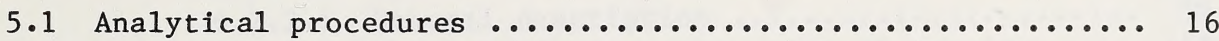

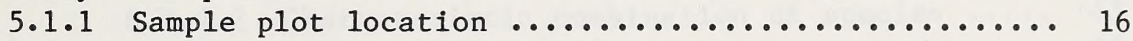

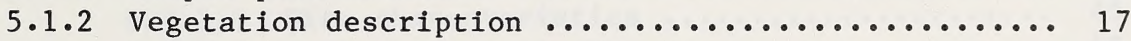

5.1 .2 .1 Vegetation stratification $\ldots \ldots \ldots \ldots \ldots \ldots 17$

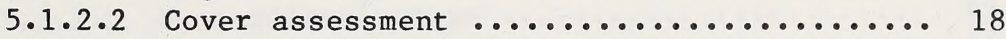

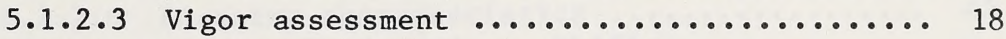

5.1.3 Soil description and soil sample analyses ........ 19

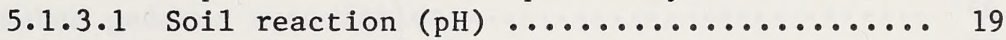

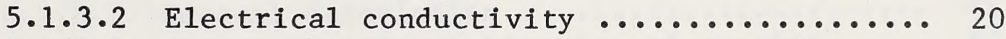

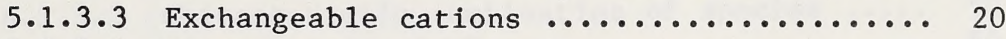

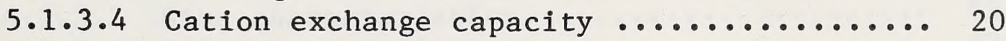

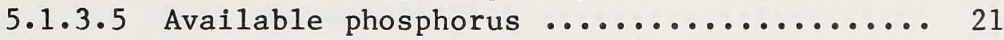

5.1.3.6 Pyrophosphate extractable iron

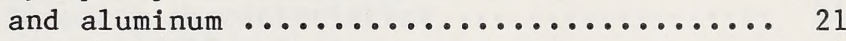

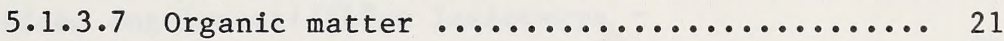

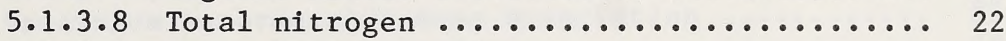

5.1.3.9 Particle size analysis ................. 23

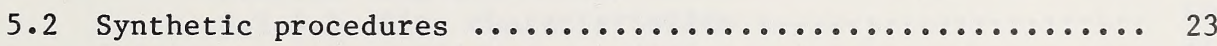

5.2.1 Grouping sample plots for determination of

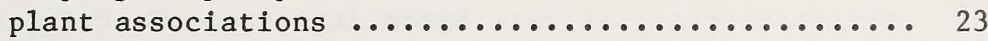

5.2.2 Characterization of the plant associations ....... 24

5.2.3 Correlation with environmental characteristics .... 25

5.3 Some descriptive criteria ...................... 25

5.3.1 Hygrotrope, trophotope and edatopic grid matrix .... 26

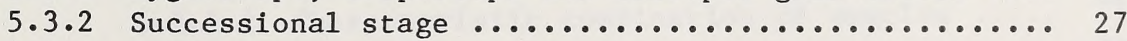

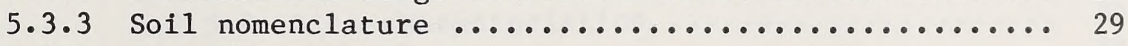

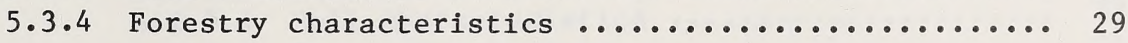


TABLE OF CONTENTS (continued)

6. DESCRIPTION OF THE FORESTED PLANT ASSOCIATIONS $\ldots \ldots \ldots \ldots \ldots \ldots \ldots$

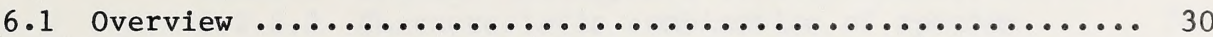

6.2 Plant associations of the lower subzone ............ 30

6.2.1 Pinus contorta - Juniperus communis -

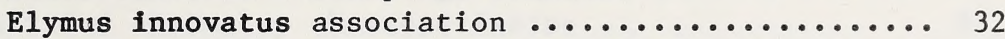

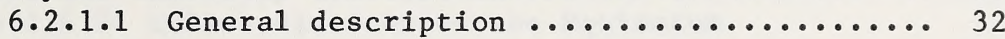

6.2.1.2 Characteristic combination of species .... 36

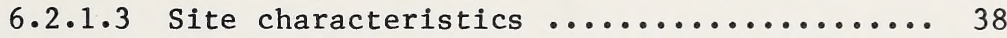

6.2 .1 .4 Soil characteristics ............... 38

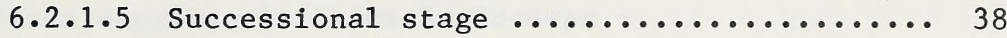

6.2 .1 .6 Forestry characteristics .............. 38

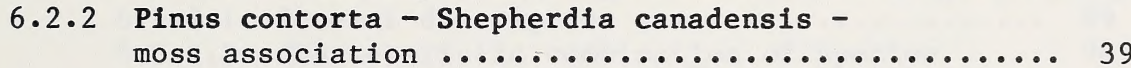

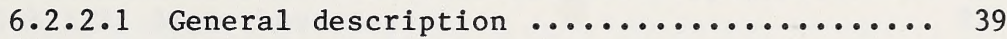

6.2.2.2 Characteristic combination of species .... 43

6.2 .2 .3 Site characteristics ............... 45

6.2 .2 .4 Soil characteristics $\ldots \ldots \ldots \ldots \ldots \ldots \ldots \ldots . \ldots \ldots$

6.2 .2 .5 Successional stage ................ 45

6.2 .2 .6 Forestry characteristics ............ 45

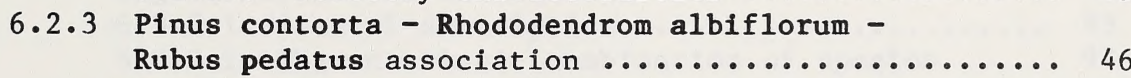

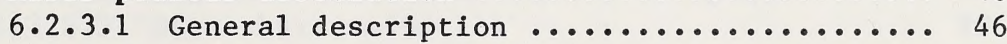

6.2.3.2 Characteristic combination of species .... 50

6.2 .3 .3 Site characteristics ............... 52

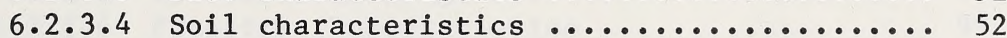

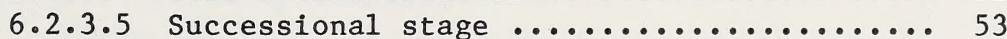

6.2.3.6 Forestry characteristics ............. 53

6.2.4 Picea engelmannil/Abies lasiocarpa -

Vaccinium membranaceum-moss association ......... 53

6.2 .4 .1 General description ................ 53

6.2.4.2 Characteristic combination of species .... 60

6.2 .4 .3 Site characteristics ..................6 60

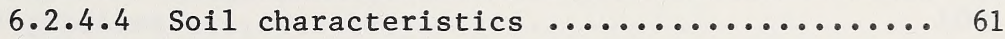

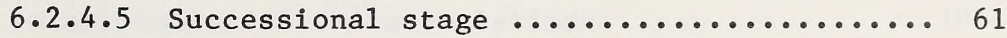

6.2 .4 .6 Forestry characteristics ............. 61

6.2.4.7 Subassociations of the moss association ... 62

6.2.5 Pinus contorta - Alnus crispa -

Arnica cordifolia association ............. 66

6.2 .5 .1 General description .................... 66

6.2.5.2 Characteristic combination of species .... 72

6.2 .5 .3 Site characteristics ................. 72

6.2 .5 .4 Soil characteristics .............. 73

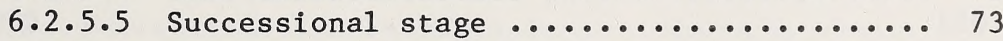

6.2 .5 .6 Forestry characteristics ............ 73 

TABLE OF CONTENTS (continued)

6.2.6 Picea mariana - Salix spp. - Equisetum spp.

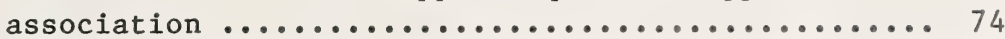

6.2.6.1 General description ......................... 74

6.2.6.2 Characteristic combination of species .... 78

6.2 .6 .3 Site characteristics ............... 80

$6.2 \cdot 6.4$ Soil characteristics .................. 81

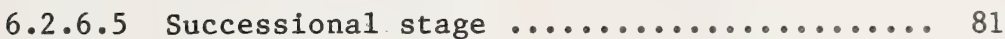

6.2 .6 .6 Forestry characteristics .............. 81

6.2.6.7 Subassociations of the Equisetum

association ....................... 81

6.3 Plant associations of the upper subzone .............. 86

6.3.1 Picea engelmannil/Abies lasiocarpa -

Pedicularis bracteosa association ............ 86

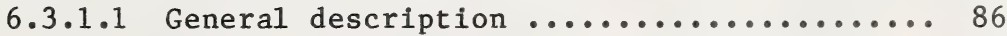

6.3.1.2 Characteristic combination of species .... 90

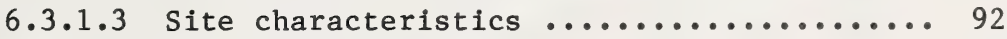

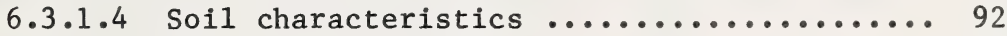

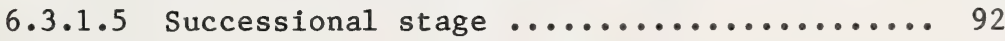

6.3.1.6 Forestry characteristics .............. 92

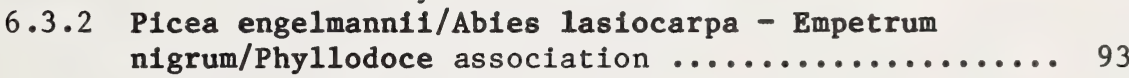

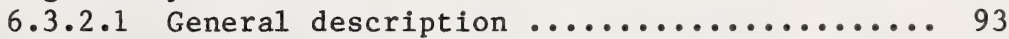

6.3.2.2 Characteristic combination of species ..... 97

6.3.2.3 Site characteristics ................. 99

6.3.2.4 Soil characteristics .................. 99

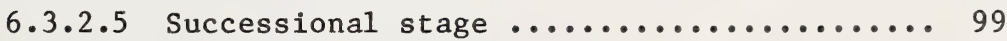

6.3.2.6 Forestry characteristics ............. 99

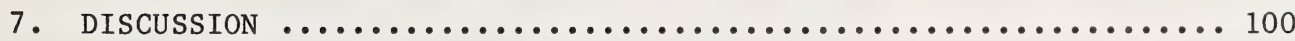

7.1 Vegetation similarity among the associations ........... 100

7.2 Sequence of associations in relation to

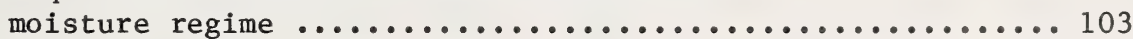

7.3 Sequence of associations in relation to

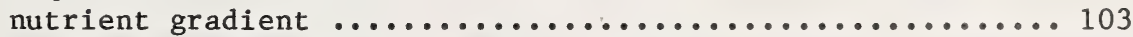

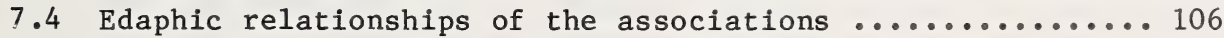

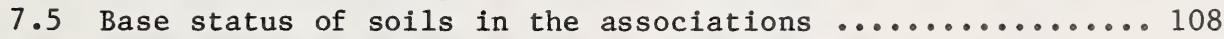

7.6 Total nitrogen in soils of the associations ............. 110

7.7 Available phosphorus in soils of

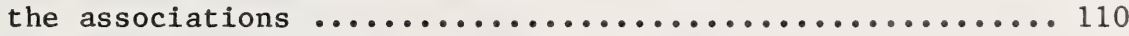

7.8 Forest productivity of the associations ............. 112

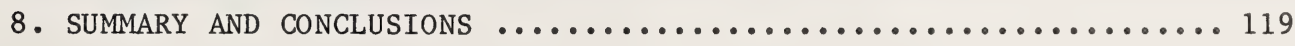

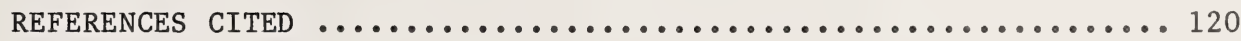





\section{ABSTRACT}

Based on the concepts and approach used for biogeoclimatic ecosystem classification, this report provides a classification of forest ecosystems that occur in the northern regions of the Engelmann spruce subalpine fir zone (subalpine zone) in Alberta. The study area extended latitudinally from about $52^{\circ} 00 \mathrm{~N}$ to $54^{\circ} 30 \mathrm{~N}$, from the upper drainage basins of the Red Deer River north almost to Grande Prairie, in an altitudinal range from about 1,300 to 2,200 meters above sea level.

A total of eight forested plant associations were recognized and described. These associations represent well developed forest ecosystems of the northern subalpine regions of Alberta. Six of the eight associations represented forest ecosystems of the lower subzone and two represented those in the upper subzone.

The descriptions provided in this report include information on vegetation structure (stratification, floristic characteristics, species coverage assessment, and the characteristic combination of species for each forested plant association), soil characteristics (horizon determination, soil classification, and physical and chemical properties), and forestry characteristics (total volume of tree stems, mean annual increment, stand age, number of trees per hectare, and site indices of major tree species). Ecological characteristics of the associations and relationships among the associations, as well as relationships between the associations and environment are also outlined. 



\section{ACKNOWLEDGEMENTS}

This report is a result of a work done in 1981 under contract from the Alberta Department of Energy and Natural Resources. I would like to express my sincere gratitude to the following people: Mr. J. Soos, Director, Research Branch, Alberta Forest Service, for financial support and continuous encouragement which enabled me to complete this study; Dr. V.J. Krajina of the Department of Botany, University of British Columbia, for his warm encouragement and advice as well as providing me with office facilities; Dr. E.B. Peterson, President, Western Ecological Services (B.C.) Ltd., for his kind arrangement of a contract on my behalf and for his continuous support; Ms. S. Phelps of Forest Planning Systems Ltd., Vancouver, for her co-operation in data processing; and team members of the Alberta biogeoclimatic classification project for their cooperation in data processing. I would also like to thank Glenda Mersky and Michelle Peterson for editorial assistance and manuscript preparation. 

Figure 1. Distribution of Engelmann spruce-subalpine

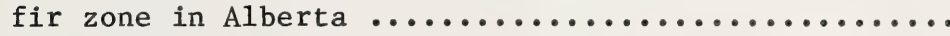

Figure 2. Forest harvesting in the northern subalpine

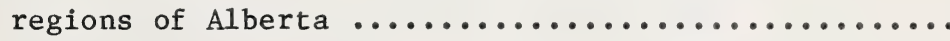

Figure 3. Commercial forest production from the northern

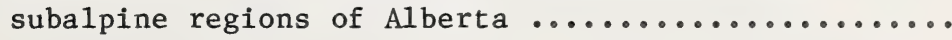

Figure 4. Climate of the subalpine zone. The illustrated data from Clearwater Ranger Station represent climate in the lower portion of the lower subzone of the subalpine zone $\ldots \ldots \ldots \ldots \ldots \ldots \ldots$

Figure 5. Characteristic mountainous topography in the

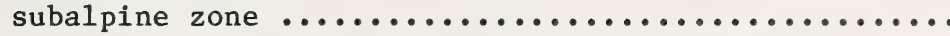

Figure 6. Vast extent of subalpine forests, dominated by closed forests of Engelmann spruce and

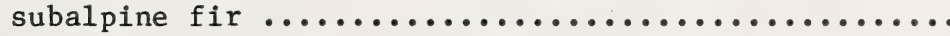

Figure 7. Closed forest typical of the lower subzone of the subalpine zone $\ldots \ldots \ldots \ldots \ldots \ldots \ldots \ldots \ldots \ldots$

Figure 8. Open forest typical of the upper subzone of the subalpine zone $\ldots \ldots \ldots \ldots \ldots \ldots \ldots \ldots \ldots$

Figure 9. Hygrotope and trophotope categories arranged

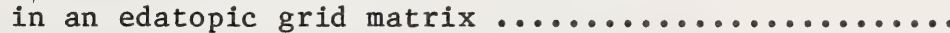

Figure 10. Edatopic position of the pine-Elymus

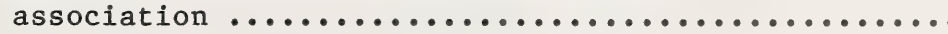

Figure 11. A forest stand of the pine-Elymus

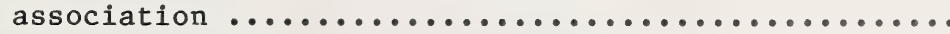

Figure 12. Soil profile of the pine-Elymus

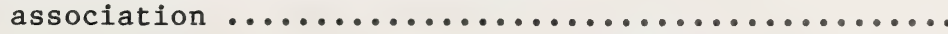

Figure 13. Vegetation and soil profiles and soil particle size distribution of the pine-Elymus

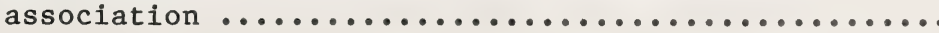

Figure 14. Edatopic position of the pine-Shepherdia association

Figure 15. A forest stand of the pine-Shepherdia association 

LIST OF FIGURES, Continued

Figure 16. Soil profile of the pine-Shepherdia

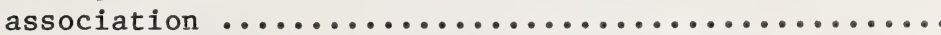

Figure 17. Vegetation and soil profiles and soil particle size distribution of the pine-Shepherdia

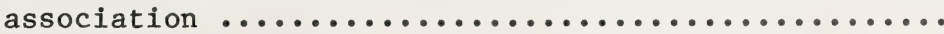

Figure 18. Edatopic position of the pine-Rhododendron

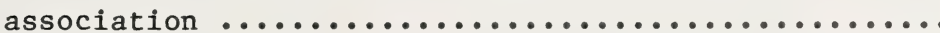

Figure 19. A forest stand of the pine-Rhododendron association

Figure 20. Soil profile of the pine-Rhododendron

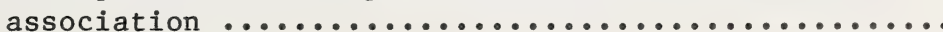

Figure 21. Vegetation and soil profiles and soil particle size distribution of the pine-Rhododendron

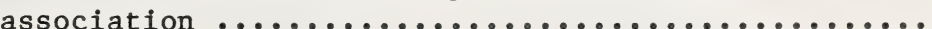

Figure 22. Edatopic position of the spruce/fir-moss association and its two subassociations (41: typical subassociation, 42: Ledum subassociation)

Figure 23. A forest stand of the Ledum subassociation

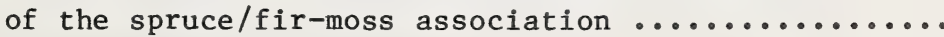

Figure 24. Soil profile of the Ledum subassociation

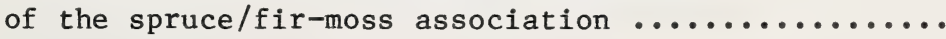

Figure 25. A forest stand of the typical subassociation

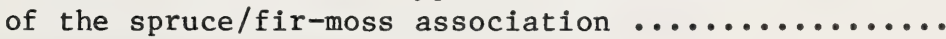

Figure 26. Soil profile of the typical subassociation

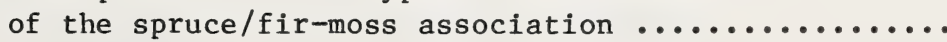

Figure 27. Vegetation and soil profiles and soil particle size distribution of the spruce/fir-moss association

Figure 28. Edatopic position of the pine-alder association ....

Figure 29. A forest stand of the pine-alder association ....... 68

Figure 30 . Soil profile of the pine-alder association ........ 68

Figure 31. Vegetation and soil profiles and soil particle size distribution of the pine-alder association ..... 

LIST OF FIGURES, Continued

Figure 32. Edatopic position of the spruce-willow-

Equisetum association and its two

subassociations (61: Equisetum sylvaticum

subassociation, 62: Equisetum pratense

subassociation)

Figure 33. A forest stand of the spruce-willow-Equisetum association

Figure 34. Soil profile of the spruce-willow-Equisetum

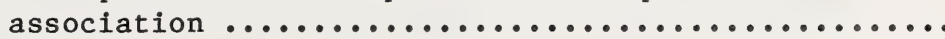

Figure 35. Vegetation and soil profiles and soil particle size distribution of the spruce-willow-Equisetum

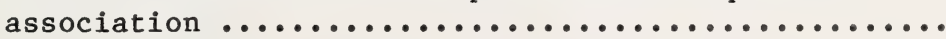

Figure 36. Edatopic position of the spruce/fir-Pedicularis association

Figure 37. A forest stand of the spruce/fir-Pedicularis association

Figure 38. Soil profile of the spruce/fir-Pedicularis association

Figure 39. Vegetation and soil profiles and soil particle size distribution of the spruce-fir-Pedicularis

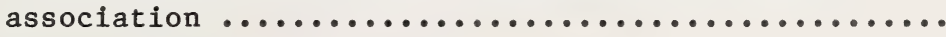

Figure 40. Edatopic position of the spruce/fir-heather association

Figure 41. A forest stand of the spruce/fir-heather association

Figure 42. Soil profile of the spruce/fir-heather

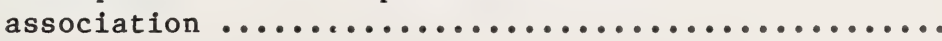

Figure 43. Vegetation and soil profiles and soil particle size distribution of the spruce/fir-heather association

Figure 44. Dendrogram showing vegetational similarity among the six forested plant associations of the lower subzone

Figure 45. Hygrotopic sequence of the six forested plant associations of the lower subzone

Figure 46. Trophotopic sequence of the six forested plant associations of the lower subzone 

LIST OF FIGURES, Continued

Figure 47. Composite edatopic positions of the six forested plant associations of the lower subzone .......... 107

Figure 48. Soil characteristics of the six forested plant associations of the lower subzone ................ 111

Figure 49. Total volume of tree stems partitioned by

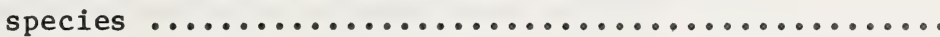

Figure 50. Tree growth characteristics of the six forested

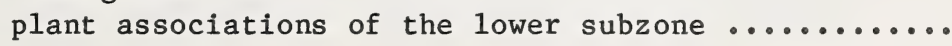



Table 1. List of plant associations recognized in the study .....

Table 2. Soil characteristics of the Pinus contorta-

Juniperus communis-Elymus innovatus association ........

Table 3. Soil characteristics of the Pinus contorta-

Shepherdia canadensis-moss association ............. 44

Table 4. Soil characteristics of the Pinus contorta -

Rhododendron-Rubus pedatus association ............ 51

Table 5. Soil characteristics of the Picea engelmannil/Abies

lasiocarpa-Vaccinium membranaceum moss association ..... 59

Table 6. Vegetation differences between the two subassociations

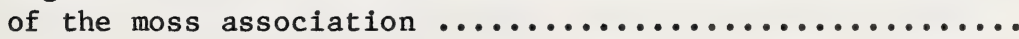

Table 7. Comparison of soil characteristics in the two

subassociations of the moss association ............. 64

Table 8. Comparison of tree growth characteristics in the

two subassociations of the moss association $\ldots \ldots \ldots \ldots \ldots$

Table 9. Soil characteristics of the Pinus contorta-Alnus

crispa-Arnica cordifolia association .............. 71

Table 10. Soil characteristics of the Picea mariana-Salix spp. -

Equisetum spp. association ..................... 79

Table 11. Vegetation differences between the two subassociations

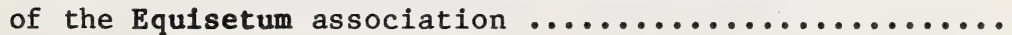

Table 12. Comparison of soil characteristics in the two subassociations of the Equisetum association .......... 84

Table 13. Soil characteristics of the Plcea engelmannil/Abies

lasiocarpa-Pedicularis bracteosa association .......... 91

Table 14. Soil characteristics of the Picea engelmannil/Abies

lasiocarpa-Empetrum nigrum/Phyllodoce association ...... 98

Table 15. Similarity coefficients among the six forested plant associations of the lower subzone ............. 101

Table 16. Base saturation, total nitrogen and available phosphorus in different soil horizons of the six forested plant associations in the lower subzone ....... 109

Table 17. Tree growth characteristics of the six forested plant associations of the lower subzone ................. 113

Table 18. Summary of environmental characteristics and mensurational variables for six associations of the lower subzone 

FORESTED PLANT ASSOCIATIONS

OF THE NORTHERN SUBALPINE REGIONS OF ALBERTA

\section{INTRODUCTION}

In Alberta, on the eastern slopes of the Rocky Mountains, a vast forest dominated and characterized by Engelmann spruce (Picea engelmannil) and subalpine fir (Abies lasiocarpa) in mature stands has developed. This type of forest occurs within elevational ranges of approximately 1,400 to $2,500 \mathrm{~m}$ above sea level (as 1) in the vicinity of $49^{\circ} \mathrm{N}$, between 1,600 and $2,450 \mathrm{~m}$ near $50^{\circ} \mathrm{N}$, between 1,400 and $2,200 \mathrm{~m}$ as 1 near $52^{\circ} \mathrm{N}$ and from 1,300 to $2,000 \mathrm{~m}$ as 1 near $54^{\circ} 30 \mathrm{~N}$. This forested area is customarily called the subalpine zone (Figure 1). The northern subalpine regions of Alberta, as referred to in this report, include an area latitudinally from about $52^{\circ} 00 \mathrm{~N}$ to $54^{\circ} 30 \mathrm{~N}$, from the upper drainage basins of the Red Deer River north almost to Grande Prairie, with an altitudinal range from about 1,300 to 2,200 m as1. The study area also includes high elevations in the Swan Hills where the subalpine zone occurs as an isolated outlier. The subalpine zone is one of the most productive forested zones in Alberta and because it covers a relatively large geographical area along the east slopes of the mountains, this zone is a vitally important area to the province from a forestry point of view (Figure 2 and 3 ).

Since 1976, the Alberta Forest Service, in co-operation with the Canadian Forestry Service, has been developing an ecosystematic classification of forests in Alberta, in terms of a biogeoclimatic ecosystem units, to provide an ecological rationale for sound forest management practices. Considerable progress has been made to date (Kojima 1980; Kojima and Krumlik 1977, 1979a 1979b, 1980; Krumlik and Johnson 1978; Krumlik et al 1978, 1979; Northern Forest Research Centre 1977). This report is a further contribution to the development of a biogeoclimatic classification system for Alberta. 



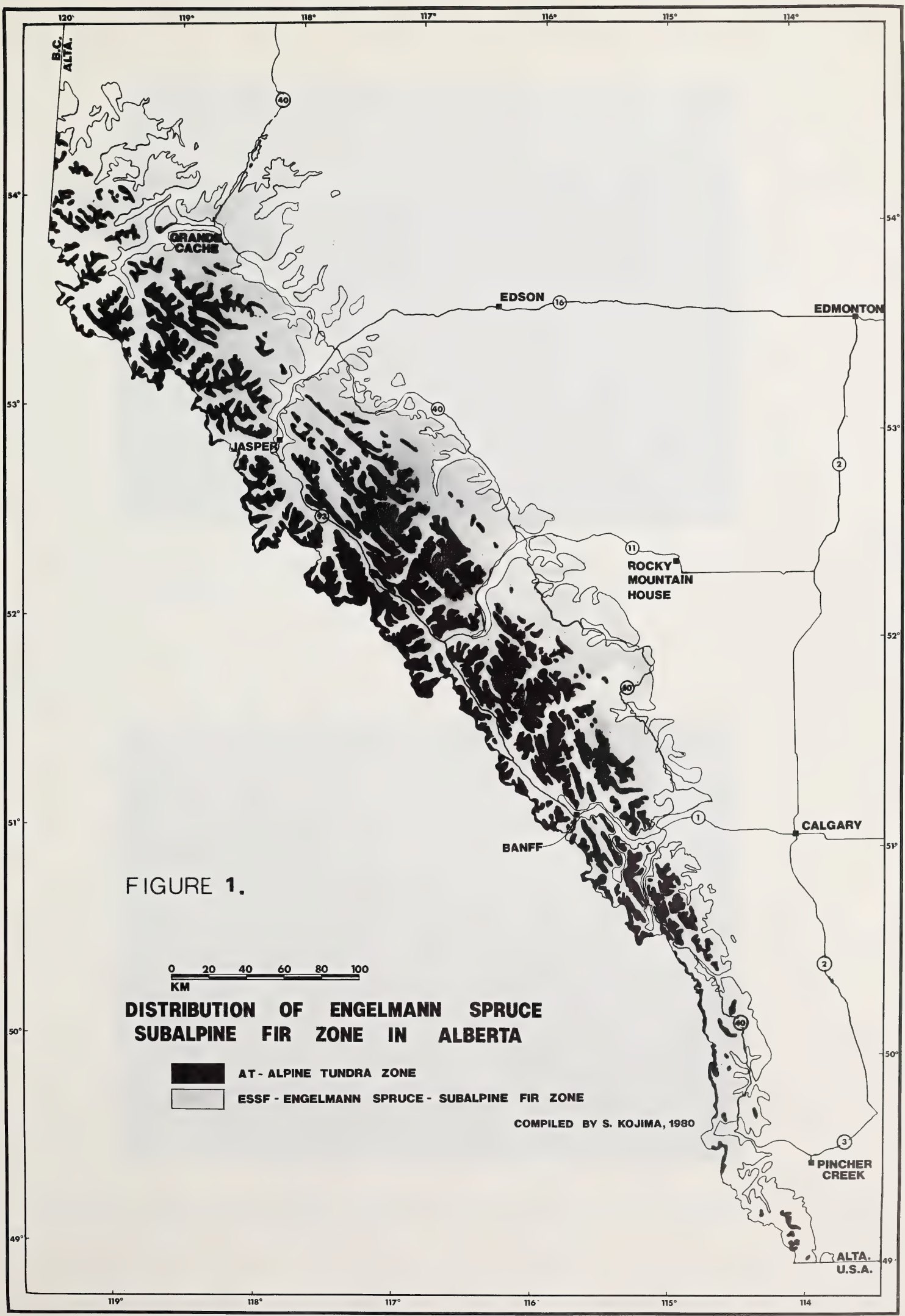





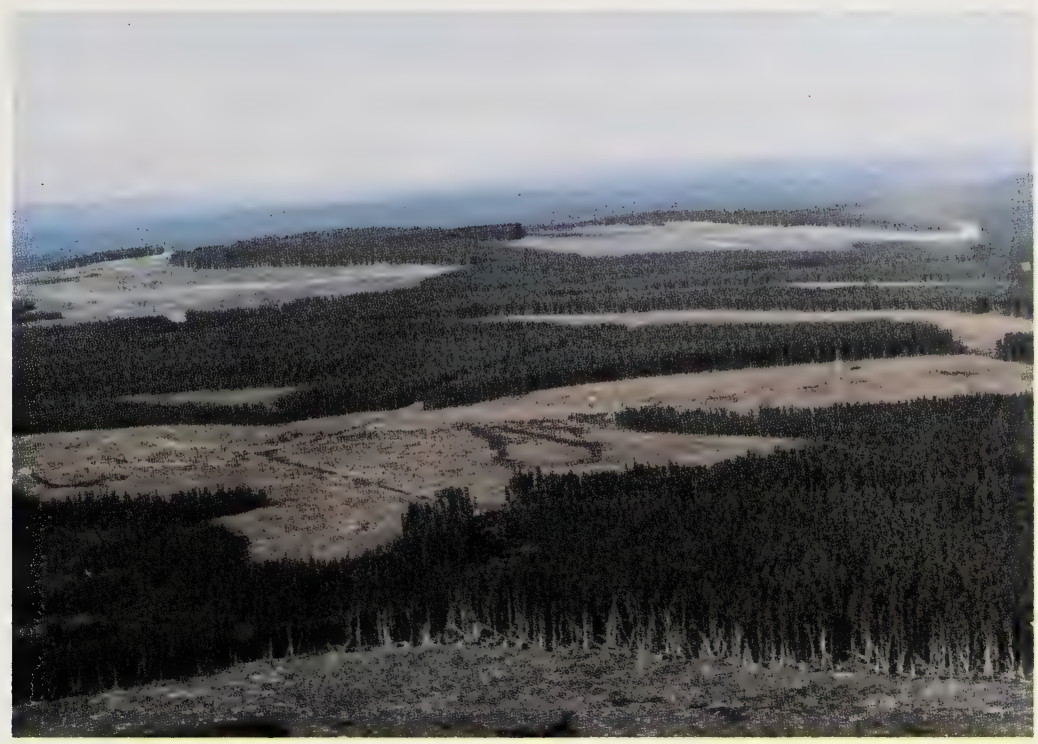

Figure 2. Forest harvesting in the northern subalpine regions of Alberta

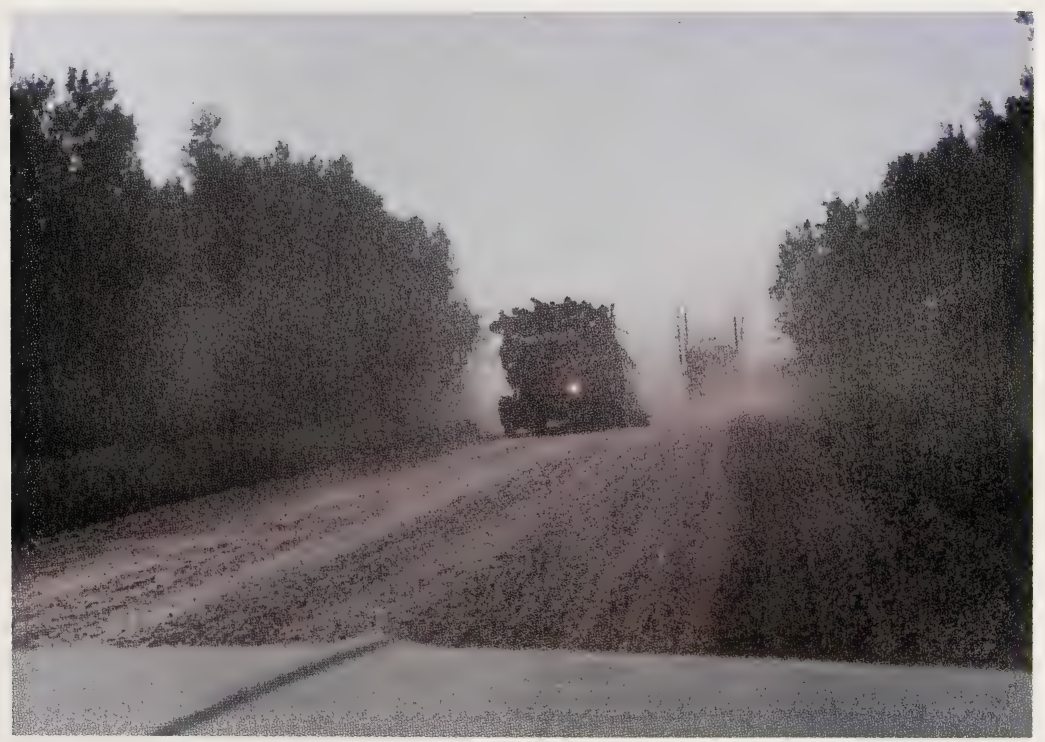

Figure 3. Commercial forest production from the northern subalpine regions of Alberta 

Based on data obtained from the project, this report presents a classification of forest ecosystems, following the framework of the biogeoclimatic ecosystem classification (sensu Krajina and his students), along with basic information on vegetation, soils and forestry characteristics of forested plant associations of the northern subalpine regions of Alberta. This information provides background information for development of ecologically sound forest management techniques, as exemplified in British Columbia (Klinka 1976, 1977a, 1977b; Klinka et al. 1979, 1980, 1981; Klinka and Carter 1980). However, it should be noted that this report presents only a tentative classification of the area because of limited field investigation and the extensive, rather than intensive, nature of the project. Future effort is very much needed to improve and refine the classification presented here. 



\section{SOME BASIC CONCEPTS}

The biogeoclimatic ecosystem classification system developed by V.J. Krajina and his students is a holistic classification of terrestrial ecosystems. It provides a classification at two different levels of synecological integration - generalized (biogeoclimatic) units and detailed (biogeocoenotic) units.

A biogeoclimatic zone is a basic unit of the classification at a generalized level. It is a geographic segment of the earth's surface characterized by three major parameters: 1) macroclimate as defined by Köppen's climatic classification system; 2) zonal soil (sensu Sibirtzev 1898) or predominant soil-forming processes associated with the macroclimate; and 3 ) zonal vegetation as expressed by climatic climax vegetation.

Of the three parameters that define biogeoclimatic zones, macroclimate is the most important as it, while largely independent from others, dictates the course of soil and vegetation development to a large extent. Moreover, despite the fact that local site-specific environments vary greatly, the macroclimate remains more or less uniform through a relatively large area and is relatively stable for a considerable period of time. Thus, macroclimate can provide a framework for geographic subdivisions, in each of which ecological processes are governed by the common denominator of a relatively uniform macroclimate.

Climatic climax vegetation is another important parameter to define biogeoclimatic zones. This is vegetation which, on mesic habitats that are intermediate in moisture regime, has reached a stage of more or less dynamic equilibrium after a sequence of vegetation succession. On mesic habitats, influences from edaphic characteristics are less pronounced than they are at dry or wet extremes of the moisture regime. The climatic climax vegetation of mesic sites is therefore considered to be a good reflection of the influences of macroclimatic control. Such vegetation may serve as a "key ecosystem" or "benchmark ecosystem" to identify a biogeoclimatic zone and to determine its 

geographical extent. Thus, in practical terms, a biogeoclimatic zone is a geographic area that is potentially delineated by a single climatic climax vegetation type on mesic habitats.

Because a biogeoclimatic zone covers a broad geographic area, it necessarily includes a great diversity of habitats that range from dry to wet and from nutritionally poor to fertile. Reflecting such environmental diversity, ecosystems that are expressed in the form of vegetation and soils, vary greatly within a biogeoclimatic zone. Therefore, a biogeoclimatic zone is quite heterogeneous from a site-specific local ecosystem point of view. Such ecosystematic variations, however, can be further classified on the basis of their regular and repetitive patterns of occurrence. This step involves classification at the biogeocoenotic level.

Each individual ecosystem that develops on a particular habitat may be called a biogeocoenosis (sensu Sukachev 1958, Sukachev and Dylis 1964). A biogeocoenosis, by definition, is a complex of physical and biological components, that occupy a specific space on the earth at a given time. It is the smallest functional unit of nature, activated by a constant flow of energy and material, and governed by physico-chemical laws. It is a concrete manifestation of an ecosystem.

Although, in some respects, a biogeocoenosis is synonymous with ecosystem (sensu Tansley 1935), ecosystem is a more general term. By definition, the term ecosystem is applicable to any rank of hierarchy or level of synecological generalization, ranging from a small water pool to the entire earth. A forest, characterized by the presence of the tree layer, is one explicit form of biogeocoenosis.

A biogeocoenosis may be represented for classification purposes by information from a sample plot or relevé. Sample plots that represent various biogeocoenoses may be assembled and grouped according to their similiarity. Each group of sample plots represents a more or less homogeneous taxonomic unit, referred to as a typified ecosystem or a biogeocoenoses. 

An assumption, however, needs to be made that vegetation is a concrete manifestation of ecosystems and that by classifying vegetation one is also classifying ecosystems expressed in the form of vegetation (Kojima 1981). Plant associations (sensu Braun-Blanquet (1928), as modified by Krajina 1960 and as used by Krajina and his students) may serve as a fundamental unit for this level of classification. It is the smallest unit discriminable floristically as well as environmentally. It is an abstract unit based on sample plots that possess similar vegetation structure and which occurs repeatedly on similar habitats. Plant association is somewhat synonymous to biogeocoenotic association (sensu Klinka et al. 1979), but in this report the term 'plant association' is used throughout. Nomenclature of plant associations is usually based on species that best characterize and represent the associations. 

The subalpine zone, as used in this report, coincides with the Engelmann spruce-subalpine fir biogeoclimatic zone first proposed by V.J. Krajina $(1959,1965,1969)$. This zone develops on mid to high elevations in mountainous regions of western North America. Geographically the zone extends from the east slopes of the Coast and Cascade mountains eastwards to the east slopes of the Rocky Mountains. Latitudinally, the zone extends from $57^{\circ} 00 \mathrm{~N}$ southwards to $38^{\circ} 50 \mathrm{~N}$ along the Rocky Mountains (Krajina 1965, 1969, 1973, 1975, Farley 1979; Küchler 1964; Franklin and Dyrness 1969, Pfister et al. 1977; Rowe 1972; North 1976). In Alberta, the subalpine zone occurs mainly on the east slopes of the Rocky Mountains (Figure 1), and partly in the Swan Hills (Kojima 1980). It is somewhat comparable to the East Slope Rockies Section of the Subalpine Forest Region, as defined by Rowe (1972).

The subalpine zone develops in a cool and humid mountain climate, classified as Dfc by Köppen as modified by Trewartha (1957). By this classification, the subalpine climate has one to three months of mean monthly temperatures above $10^{\circ} \mathrm{C}$. The climate is characterized by: 1) a high amount of precipitation, especially snow; 2) an extended cloudy period; 3) a short growing season of 70 to 100 days per year; 4) low summer temperatures; and 5) a low rate of evapotranspiration.

Climatic characteristics of the subalpine zone in Alberta tend to be relatively continental due to its location on the east slope of the Rocky Mountains. Climatic characteristics of the zone within Alberta may be summarized as follows: 1) cool and humid climate with mean annual temperatures ranging from -3 to $2^{\circ} \mathrm{C}$ and mean annual precipitation ranging from 450 to $1,000 \mathrm{~mm}$, of which approximately 40 to $60 \% \mathrm{falls}$ as snow; 2) low evapotranspiration rate with potential evapotranspiration ranging from 300 to $450 \mathrm{~mm}$ per year, as a result of which there is practically no climatic water deficit, as calculated by Thornthwaite (1948); and 3) relatively high continentality with continental indices (Trewartha 1968) ranging from 36 to 41 , which is evidently higher than 

those of the subalpine zone in British Columbia. Figure 4 summarizes climatic characteristics of the subalpine zone in Aberta.

Topography of the subalpine zone in Alberta is characteristically mountainous (Figure 5). The zone generally develops on steep terrain, but local topography varies greatly from level sites on river flats, terraces, till plains and old lake beds to very steep sites on eroded escarpments, upper mountain slopes and cliffs. Parent material varies from residues of parent rocks to deposits of alluvial, colluvial, lacustrine, aeolian and glacial origins. However, most surface deposits are glacial in origin, but frequently lacustrine at lower elevations, with weathered residual parent materials at higher elevations of mountain slopes (Hardy 1967, Rutter 1972).

Soils in the subalpine zone of Alberta cover a wide range of soil classification categories. However, the majority are brunisols with some occurrences of podzols on well drained sandy substrates; some luvisols occur on substrates of lacustrine origin (Walker et al. 1978; Krumlik et al. 1978, 1979; Twardy and Corns 1980).

Vegetation in well matured stands on mesic habitats of the subalpine zone in Alberta is represented by closed forests of Engelmann spruce and subalpine fir (Figure 6), where ground vegetation is overwhelmed by a well developed moss layer and a depauperated growth of shrubby and herbaceous species. However, as elevation increases, trees tend to become short and stunted and occur in groups on well protected sites, to eventually form open forests at higher elevations. Thus, the subalpine vegetation may be physiognomically divided into two units: closed forests at lower elevations and open forests at higher elevations. These two physiognomic subdivisions represent the lower and upper subzones of the subalpine zone, respectively.

Lodgepole pine (Pinus contorta) is common throughout the subalpine zone. It frequently forms pure even-aged stands that develop after some disturbance and indicate seral stages of vegetation succession. The pine stands will eventually succeed to spruce-fir 



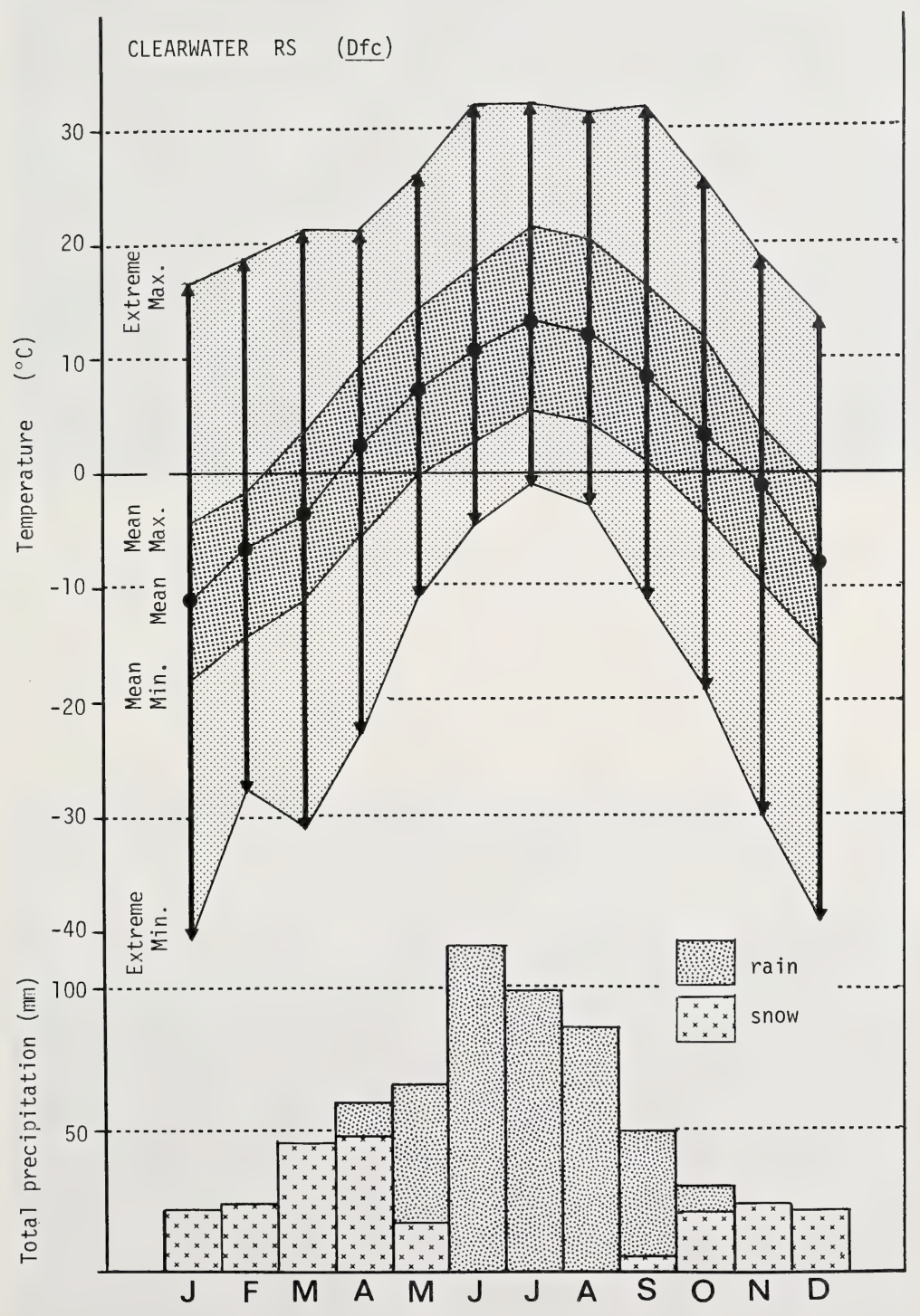

Figure 4. Climate of the subalpine zone. The illustrated data from Clearwater Ranger Station represent climate in the lower portion of the lower subzone of the subalpine zone 



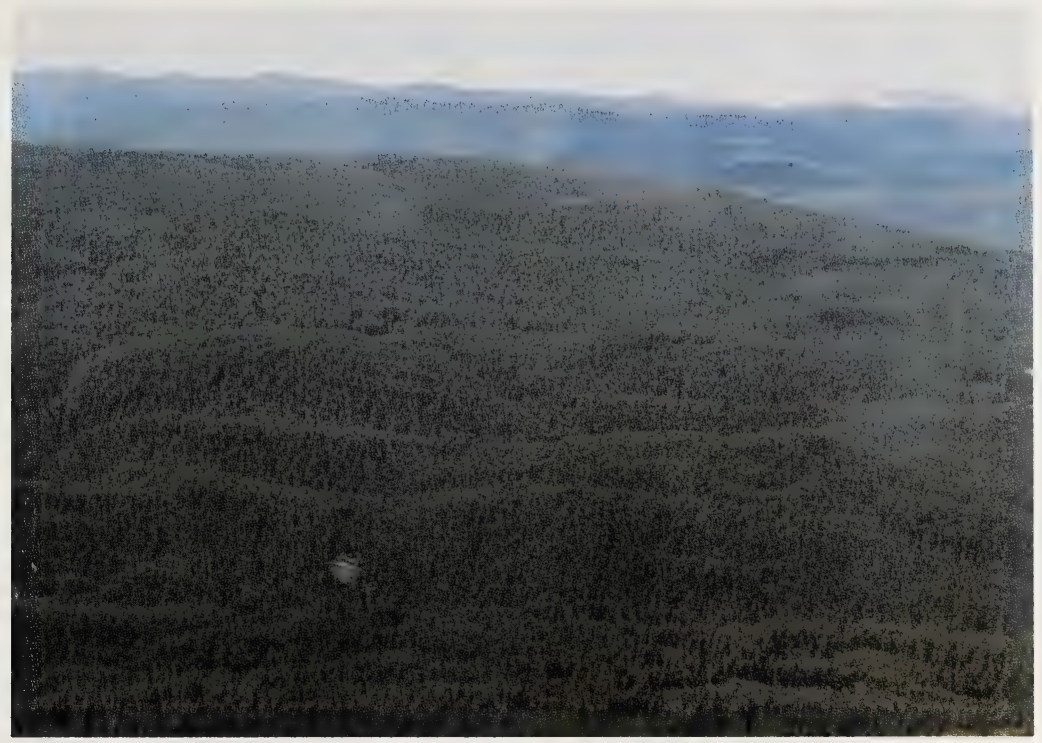

Figure 5. Characteristic mountainous topography in the subalpine zone

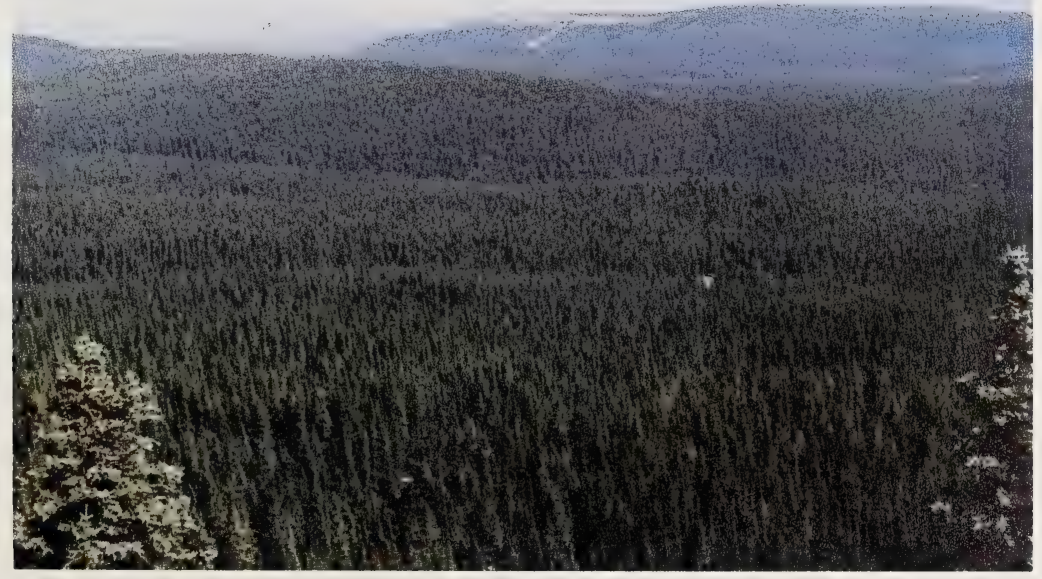

Figure 6. Vast extent of subalpine forests, dominated by closed forests of Engelmann spruce and subalpine fir 

forests except on extremely well drained sites where lodgepole pine may self-perpetuate to form an edaphic climax of xeric habitats.

White spruce (Picea glauca), including hybrids with Engelmann spruce ( $P$. engelmannii), develops on poorly drained habitats with a luxurious growth of shrubby and herbaceous species. In spruce stands, the ground vegetation is usually characterized by a well developed cover of Equisetum spp. Spruce forests represent an edaphic climax on habitats with poorly drained but fertile soils.

The subalpine vegetation may be floristically characterized by presence of the following species:

$\begin{array}{ll}\text { Abies lasiocarpa } & \text { Phyllodoce glanduliflora } \\ \text { Antennaria lanata } & \text { Rhododendron albiflorum } \\ \text { Aquilegia flavescens } & \text { Rubus parviflorus } \\ \text { Arnica cordifolia } & \text { Rubus pedatus } \\ \text { Arnica latifolia } & \text { Salix barrattiana } \\ \text { Aster ciliolatus } & \text { Salix farrae } \\ \text { Dryopteris austriaca } & \text { Salix myrtillifolia } \\ \text { Cassiope mertensiana } & \text { Salix vestita } \\ \text { Cassiope tetragona } & \text { Sambucus pubens } \\ \text { Erigeron peregrinus } & \text { Senecio triangularis } \\ \text { Gaultheria hispidula } & \text { Stenanthium occidentale } \\ \text { Ledum glandulosum } & \text { Streptopus roseus } \\ \text { Menziesia ferruginea } & \text { Tiarella trifoliata } \\ \text { Oplopanax horridus } & \text { Vaccinium membranaceum } \\ \text { Pedicularis bracteosa } & \text { Vaccinium myrtillus } \\ \text { Picea engelmannii } & \text { Vaccinium scoparium } \\ \text { Pinus contorta } & \text { Valeriana sitchensis } \\ \text { Phyllodoce empetriformis } & \text { Veratrum eschscholtzii } \\ & \end{array}$



4. SUBZONAL DIVISION OF THE SUBALPINE ZONE IN ALBERTA

Because the subalpine zone in Alberta covers an extensive area of the eastern slopes of the Rocky Mountains from $49^{\circ} \mathrm{N}$ northwards to $54^{\circ} 30 \mathrm{~N}$ and from low $(1,300 \mathrm{~m}$ as 1$)$ to high elevations $(2,500 \mathrm{~m}$ as1), it encompasses a great diversity of variation in terms of floristic composition, vegetational structure and environmental characteristics. Based on geographic trends of these variations, Kojima (1980) proposed four subzonal units within the subalpine zone. The subalpine zone was divided into northern and southern units based mainly on floristic and vegetational differences; each of these units was further subdivided into upper and lower units based on environmental differences related to elevation and as expressed by physiognomic characteristics of the tree cover. Thus, the entire subalpine zone in Alberta may be divided into four units - northern upper subzone, northern lower subzone, southern upper subzone and southern lower subzone.

Floristically, the southern units are characterized by common occurrences of the following species that are less common or entirely lacking in the northern units: Angelica dawsonil, clintonia uniflora, Elymus glaucus, Larix 1yallii, Mahonia repens, Philadelphus lewisii, Lonicera utahensis, Phisocarpus malvaceus, Rubus parviflorus, Pteridium aquilinum and Xerophyllum tenax.

Vegetationally, the southern units are characterized by: 1) abundant and good growth of Pinus albicaulis; 2) occurrences of well developed stands of Larix lyallii in the upper subunit; 3) common occurrences of the Menziesia type and Vaccinium scoparium type, with the latter type tending to be restricted to higher elevations; and 4) gradual decrease of the moss type as well as fading out of the Elymus innovatus type and Equisetum type, all of which are quite common throughout the northern units.

The upper and lower units are separated mainly by physiognomy of vegetation and partly by floristic characteristics. In general, 



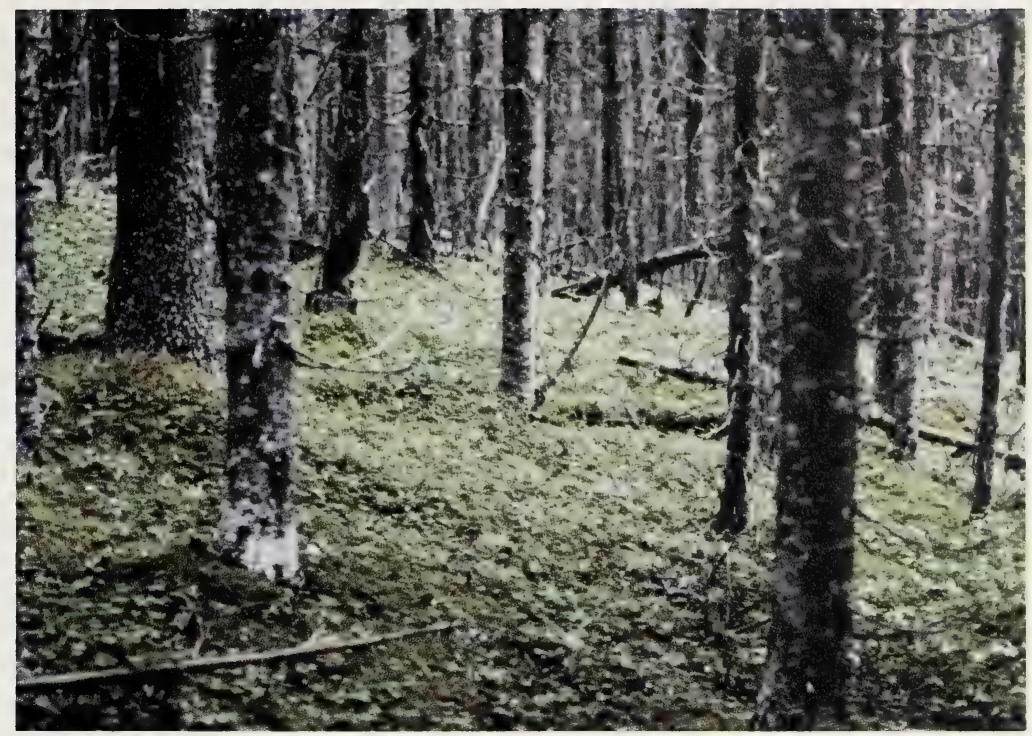

Figure 7. Closed forest typical of the lower subzone of the subalpine zone

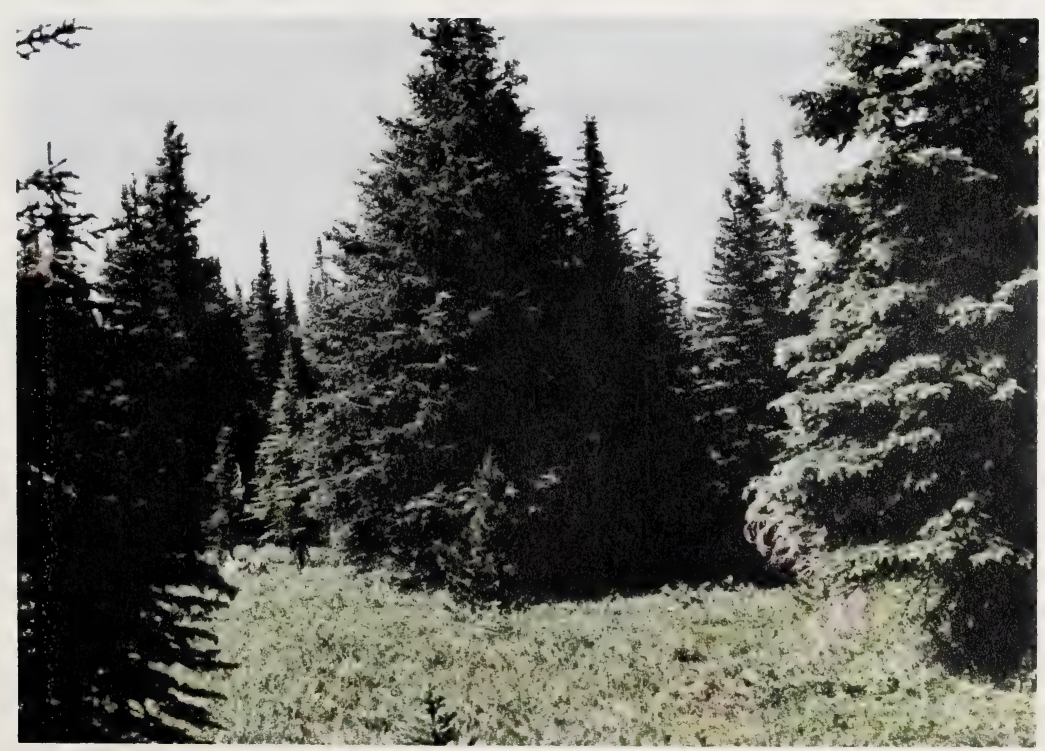

Figure 8. Open forest typical of the upper subzone of the subalpine zone 

vegetation of the lower units, in both the northern and southern subalpine areas, is characterized by well developed closed forests of mainly Abies lasiocarpa and Picea engelmannil on moderately drained habitats (Figure 7). The vegetation of the upper units, on the other hand, is represented by open forests (Figure 8) of the same conifers. Because of the harsh climate at higher elevations, tree growth is very much impeded and trees tend to occur as isolated clumps on well protected sites. In between tree patches, alpine heath vegetation, mainly Cassiope tetragona, Cassiope mertensiana, Phyllodoce empetriformis and Phyllodoce glanduliflora develops. Vegetation of the upper subzones, therefore, tends to show a mosaic pattern of tree islands and alpine heath which has been termed 'Parkland' (sensu Brooke et al. 1970) in subalpine studies elsewhere.

There are some differences in floristic structure between the upper and lower subzones. Besides the heath species mentioned above, occurrence of the following species is an indication of the upper subzone: Antennaria lanata, Arenaria capillaris, Carex nigricans, Carex nardina, Deschampsia atropurpurea, Erigeron peregrinus, Hieracium gracile, Luzula wahlenbergii, Pedicularis bracteosa, Pedicularis contorta, Poa alpina, Poa cusickil, Poa nervosa, Potentilla diversifolia, Salix arctica, Salix barrattiana, Salix nivalis, Trollius a.lbiflorus and Vaccinium scoparium.

A tentative key to identify the four subzones of the subalpine zone in Alberta was provided by Kojima (1980). Determination of the geographic extent of the northern and southern subzones needs more thorough study. Presently available information suggests that the border between the northern and southern subzones in Alberta lies somewhere in the vicinity of $52^{\circ} \mathrm{N}$, although this estimate requires verification. 



\section{METHODS AND PROCEDURES}

This study basically followed the methods of biogeoclimatic classification described by Brooke et al. (1970) and by Kojima and Krajina (1975), with a slight modification specifically suited to ecosystems of Alberta. The field investigation was initiated in 1977 and continued up to and including the 1980 field season. A total of 411 sample plots were established to represent a wide range of ecosystems of most of the forested biogeoclimatic zones in Alberta. of the 411 Alberta sample plots, 79 were selected for description of the northern subalpine regions of Alberta. The 79 selected plots represent forest ecosystems of the northern upper subzone and the northern lower subzone of the subalpine zone within Alberta.

\subsection{Analytical Procedures}

\subsubsection{Sample plot location}

Sample plots were established to represent various forested biogeocoenoses in the study area. A $20 \mathrm{~m} \mathrm{x} 20 \mathrm{~m}$ square was usually used for the plots, although the size and shape occasionally varied to some extent in accordance with kinds and extent of biogeocoenoses. Mature stands, at least in the late intermediate to advanced stages of vegetation succession, were preferred as much as possible because such stands tended to show more pronounced characteristics of vegetation and soil development than immature stands.

Sample sites were, thus, subjectively chosen. After an extensive reconnaissance, the project leader or crew chief selected potential sample sites which were later visited by crews to document the plots in terms of general environment, vegetation, soil, and tree growth characteristics. Random or systematic sampling was not employed because of its lack of efficiency. 



\subsubsection{Vegetation description}

Vegetation was described in terms of species composition, cover assessment of species, and species vigour. Vegetation was first divided into layers and sublayers according to their life forms and height.

\subsubsection{Vegetation stratification}

For descriptive purposes in this study, vegetation was broken down into the following strata.

Tree layer (A) - a layer consisting of woody plants with a height greater than $5 \mathrm{~m}$.

Dominant tree layer or uppermost layer $\left(A_{1}\right)$ - a sublayer of the tree layer consisting of trees with crowns outstanding and forming the uppermost canopy of the forest stand.

Subordinate tree layer $\left(\mathrm{A}_{2}\right)$ - a sublayer of the tree layer consisting of trees with crowns situated under the uppermost layer, but with heights exceeding $5 \mathrm{~m}$.

Shrub layer (B) - a layer consisting of woody plants with a height not exceeding $5 \mathrm{~m}$; all seedlings or saplings of tree species less than $5 \mathrm{~m}$ are included in this layer.

Tal1 shrub layer $\left(B_{1}\right)$ - a sublayer of the shrub layer, consisting of woody plants with heights of more than $2 \mathrm{~m}$ but less than $5 \mathrm{~m}$. Low shrub layer $\left(B_{2}\right)$ - a sublayer of the shrub layer consisting of woody plants with heights of not more than $2 \mathrm{~m}$. However, such dwarf shrubs as Empetrum nigrum, Vaccinium vitis-idaea, Cassiope mertensiana, Cassipe tetragona, Phyllodoce empetriformis, Phyllodoce glanduliflora and Arctostaphylos uva-ursi are excepted. These species are placed into the herb layer for convenience.

Herb layer (C) - a layer consisting of all herbaceous plants regardless of their height and including the dwarf shrubs not listed in the low shrub $\left(B_{2}\right)$ layer.

Moss layer (D) - a layer consisting of all the bryophytes and lichens. Epiphytic layer (E) - not a distinct horizontal layer, but including al1 the epiphytic plants that occur on tree trunks and branches. 



\subsubsection{Cover assessment}

A11 the species occurring in a layer or sublayer were assessed for their coverage. For the assessment, each of the species was projected visually to the ground surface and the area covered by the species was evaluated as a per cent of the total area of the plot. The percentage was then expressed in the Domin-Krajina species significance scale as shown in the table below. By this method, one species may be counted two or more times if it appears in different layers and sublayers, as is the usual case of tree species.

$\begin{array}{cl}\text { Class } & \text { Description } \\ + & \text { Solitary, very low dominance }(0-1 \%) \\ 1 & \text { Seldom, very 1ow dominance (1-2\%) } \\ 2 & \text { Very scattered, low dominance }(2-3 \%) \\ 3 & \text { Scattered, } 10 \text { dominance }(3-5 \%) \\ 4 & \text { Covering } 5-10 \% \text { of the plot } \\ 5 & \text { Covering } 10-20 \% \text { of the plot } \\ 6 & \text { Covering } 20-33 \% \text { of the plot } \\ 7 & \text { Covering } 33-50 \% \text { of the plot } \\ 8 & \text { Covering } 50-75 \% \text { of the plot } \\ 9 & \text { Covering more than } 75 \% \text { but } 1 \text { ess than } \\ 10 & \text { Covering } 100 \% \text { of the plot }\end{array}$

\subsubsection{Vigor assessment}

Vigor is a measure of how well a species responds to the particular environment of the site where it grows. When a species' ecological requirement matches closely with the environmental characteristics of the site, the species shows the best performance, exemplified by luxurious growth with robustness of leaves and stems, good blooming and fruiting, and good coloration of leaves. Based on the performance of species in a particular site, vigor was assessed in four broad classes: 4 - good; 3 - fair; 2 - poor; and 1 - barely surviving. 

Tables of vegetation data are available upon request from the Director, Research Branch, Alberta Forest Service*.

\subsubsection{Soil description and soil sample analyses}

For each plot, one soil pit was dug to observe and describe the soil profile in the field and to collect soil samples for later analyses. Soil profiles were described in terms of horizons, depth and thickness of horizons, color, structure, texture, boundary, presence or absence of mottlings and effervescence, root distribution, stoniness, and provisional determination of soil classification. Descriptions were in accordance with the Canadian Soil Survey Committee (1978).

Soil samples representing different horizons were collected. After being air-dried at room temperature, the samples were sifted with a $2 \mathrm{~mm}$ sieve and processed for chemical and physical analyses, including soil reaction $(\mathrm{pH})$, electrical conductivity, exchangeable cations ( $\mathrm{Ca}, \mathrm{Mg}$, $\mathrm{Na}, \mathrm{K})$, cation exchange capacitiy, available phosphorus, iron, and aluminum (for selected samples), organic matter, total nitrogen, and particle size analysis.

Following is a brief description of the analytical procedures, as described by Krumlik et al. (1978).

\section{1 .3 .1 Soil reaction $(\mathrm{pH})$}

The $\mathrm{pH}$ was determined on a soil suspension with a soil-towater ratio of $1: 1$ for mineral soils, $1: 5$ for Ah horizons, and $1: 10$ to 1:20 for organic soils (depending upon their absorption properties). After 30 minutes of equilibration on a reciprocating shaker, the $\mathrm{pH}$ of the suspension was measured using a combination electrode $\mathrm{pH}$ meter (Fisher Accumet, mode1 310). The suspension was stirred well with a glass rod and allowed to settle for 30 seconds just prior to immersing the electrode.

* Postal Bag 6343, Spruce Grove, Alberta, TOE $2 \mathrm{CO}$. 



\subsubsection{Electrical conductivity}

Total soluble salts were determined by electrical conductivity. A dip type conductivity cel1 (Type CDC 304, Conductivity Meter CDM3 Radiometer, Copenhagen) was used to measure the salt concentration of the soil suspensions. The soil-to-water ratio of the suspensions were the same as those used to determine $\mathrm{pH}$.

\subsubsection{Exchangeable cations}

The procedure used to determine the exchangeable cations in the soil sample involved displacement of the cations by saturating the exchange complex with $1.0 \mathrm{~N}$ ammonium acetate $\left(\mathrm{NH}_{4} \mathrm{OAc}\right)(\mathrm{pH} 7.0)$ and collecting the leachate. This involved filtering the ammonium acetate solution through the soil by use of a buchner funnel, using light suction and collecting the leachate containing the exchangeable cations. The specific exchangeable cations $\left(\mathrm{CA}^{++}, \mathrm{Mg}^{++}, \mathrm{K}^{+}\right.$, $\mathrm{Na}^{+}$) concentrations were determined by atomic absorption spectrophotometry (aa/ae Spectrophotometer IL 251, Instrumentation Laboratory Inc.).

\subsubsection{Cation exchange capacity}

The process used for cation exchange capacity determination was the ammonium-acetate saturation method. This involved leaching the sample with an excess of neutral, $1 \mathrm{~N}$ ammonium acetate $\left(\mathrm{NH}_{4} \mathrm{AOC}\right)$ solution to remove the exchangeable cations and to saturate the exchange complex with ammonium. The exchangeable ammonium $\left(\mathrm{NH}_{4}\right)$ was then determined by its displacement with acidified sodium chloride $(\mathrm{NaCl})$, followed by distillation.

The method involved using the $\mathrm{NH}_{4}$-saturated soil used for extracting the exchangeable cations. This saturated soil was then washed with $95 \%$ ethyl alcohol $\left(\mathrm{C}_{2} \mathrm{H}_{5} \mathrm{OH}\right)$ to remove the excess ammonium present in the soil as acetate, then leached with an acidified $10 \%$ sodium chloride solution. The leachate was transferred to Kjeldah1 

flasks for distillation. Forty percent sodium hydroxide (NaOH) was added to each flask and the solution allowed to distil and condense in a receiving flask containing $4.0 \%$ boric acid $\left(\mathrm{H}_{3} \mathrm{BO}_{3}\right)$. Titration of the distillate to a known $\mathrm{pH}$ (blank) using a standard sulphuric acid $\left(\mathrm{H}_{2} \mathrm{SO}_{4}\right)$ solution was done using an automatic titrator (RadiometerpH meter 28, Titrator II, Radiometer, Copenhagen).

\subsubsection{Available phosphorus}

Phosphorus was determined on samples using a soil/solution ratio of 1:20 for mineral soils and 1:50 for organic soils (Watanabe and 01sen 1965). The method involved extraction of the phosphorus (P) by using a $0.5 \mathrm{M}$ sodium bicarbonate $\left(\mathrm{NaHCO}_{3}\right)$ solution followed by the determination of the phosphorus colorimetrically by the ascorbic acid $\left(\mathrm{C}_{6} \mathrm{H}_{8} \mathrm{O}_{6}\right)$ method. The color intensity of the solution was measured at $882 \mathrm{mu}$ by a SP6-300 Spectrophotometer (Pye Unicam).

\subsubsection{Pyrophosphate extractable iron and aluminum}

Iron and aluminum were determined by atomic absorption spectrophometry following a sodium pyrophosphate extraction. This test was done only on selected soil profiles to determine soil classification. Finely ground (60 mesh) samples were shaken overnight in a reciprocating shaker in a $0.1 \mathrm{M}$ sodium pyrophosphate $\left(\mathrm{Na}_{2} \mathrm{P}_{4} \mathrm{O}_{7}\right.$ $-10 \mathrm{H}_{2} \mathrm{O}$ ) solution. Samples were then placed in a centrifuge (International centrifuge, model MA \& ME, International Equipment Co., Boston, Mass.) at $2300 \mathrm{rpm}$ for 15 minutes. The clear centrifugate was decanted and stored for atomic absorption spectrophotometry (aa/ae Spectrophotometer IL 251, Instrumentation Laboratory Inc.).

\subsubsection{Organic matter}

Organic matter was determined by the Walkley-Black titrimetric wet oxidation method (Greweling and Peech 1960). This method is based on spontaneous heating by the dilution of sulphuric acid $\left(\mathrm{H}_{2} \mathrm{SO}_{4}\right)$. It involves: 1) oxidizing the carbon of soil 

organic matter, using an excess amount of potassium dichromate $\left(\mathrm{K}_{2} \mathrm{Cr}_{2} \mathrm{O}_{7}\right)$ as the oxidant; and 2$)$ determining the excess potassium dichromate by titration with ferrous sulfate.

Potassium dichromate and concentrated sulphuric acid were added to the finely ground soil samples ( 60 mesh). The sulphuric acid dehydrates and breaks down the organic matter so that the carbon may be oxidized by the potassium dichromate. It also provides the heat for the reaction to proceed. Ortho-phenanthroline ferrous sulfate $(0.025 \mathrm{~m})$ solution was used as an indicator to determine the amount of excess potassium dichromate. This was done by titration and involved turning the soil-sulfuric acid-dichromate solution to a reddish-brown color (end point).

\subsubsection{Total nitrogen}

Total nitrogen was determined by the modified Kjeldahl method. The Kjeldahl method involves two steps in which the nitrogen in the sample is converted to ammonium $\left(\mathrm{NH}_{4}\right)$ by digestion with concentrated sulphuric acid $\left(\mathrm{H}_{2} \mathrm{SO}_{4}\right)$ containing substances which promote the oxidation of organic matter and the conversion of organic nitrogen to ammonium, followed by the determination of the ammonium in the digest by distillation and titration. The distillation and titration is the Winkler modification of the original procedure. It is a direct method requiring only one standard reagent and is equally accurate (Black et al. 1965) whereas the original procedure requires two standard reagents.

Finely ground soil (60 mesh) was added to Kjeldahl flasks, along with concentrated sulphuric acid and 1 package of Kelpak $\equiv_{1}^{1}$. The flasks were placed in a digestion rack and allowed to digest. After digestion, the ammonium was distilled into boric acid $\left(\mathrm{H}_{3} \mathrm{BO}_{3}\right)$

1 Matheson Scientific, East Rutherford, N.J. Each packet contains $9.9 \mathrm{~g}$ potassium sulfate $\left(\mathrm{K}_{2} \mathrm{SO}_{4}\right), 0.41 \mathrm{~g}$ mercuric oxide ( $\mathrm{HgO}$ ) and $0.08 \mathrm{~g}$ copper sulfate $\left(\mathrm{CuSO}_{4}\right)$. 

and titrated with a standard sulphuric acid using an automatic titrator (Radiometer pH meter 28, Titrator II, Radiometer, Copenhagen).

\subsubsection{Particle size analysis}

Particle size distribution expresses the proportions of the various sizes of particles which it contains. Particle size analysis was done by means of the hydrometer method. Dispersion of the soil was carried out by using an electric mixer (milkshake machine) and using Calgon as the dispersing agent. The hydrometer is then used to measure the density of the soil suspension after various times of settling. Readings were taken after $0.5,1,3,10,30,90,270$ and 720 minutes.

\subsection{Synthetic Procedures}

5.2.1 Grouping sample plots for determination of plant associations

Sample plots representing the various ecosystems of the northern subalpine regions of Alberta were assembled and manually separated in groups based on provisional determinations made in the field. The first vegetation synthesis tables were then manually constructed to indicate general vegetation characteristics and to examine validity of the provisional field determinations. At the same time, a cluster analysis, based on vegetation similarity among the plots, was conducted with the aid of an electronic computer at the University of Alberta. The results of the manual groupings and the cluster analysis were thoroughly examined and compared. Some plots were then shifted from one would-be plant association to another when needed, and some plots were completely removed from the groupings.

After preliminary grouping of the sample plots, Klinka's vegetation tabulation program was introduced to construct vegetation synthesis tables of plant associations. Computer processing of the program was carried out by Forest Planning Systems Ltd. with the 

assistance of Ms. S. Phelps. The vegetation tables were again checked and some changes of plot sequence within a grouping and some shifts of plots from one grouping to another were made when necessary. When all adjustments were completed, each vegetation synthesis table was accepted as a representation of a plant association.

\subsubsection{Characterization of the plant associations}

Because every plant species has its own definite range of tolerance to environmental variation (ecological amplitude), occurrence of a certain species indicates environmental characteristics that fall within its ecological amplitude. When more than two species, which have different but somewhat overlapping ecological amplitudes, occur together, the assemblage of species indicates a certain range of environmental variation. Thus, such an assemblage of species may be used as an indicator of a certain environmental characteristic. This is the basic rationale behind the concept of a characteristic combination of species. A plant association which develops within, and hence reflects, a certain range of environmental variation is characterized and represented by a characteristic combination of species.

When data processing for determination of plant associations was completed, species that characterized the plant associations were selected. It is generally understood that a vegetation classification unit, such as a plant association, cannot be characterized by a single species, or by even a few species. If only a single species or a small number of species were used to characterize a unit, such a unit would become an extremely large and heterogeneous entity. Thus, it is more appropriate to employ a larger number of species which occur with a high constancy and dominancy, as well as some exclusiveness, to a certain plant association.

A characteristic combination of species consists of three categories as follows (modified from Kojima 1971, Kojima and Krajina 1975): 

1) constant dominant species (CD) - those species having high constancy with presence class more than IV (occurring in more than $60 \%$ of the sample plots) and high dominancy (with average species significance more than 5);

2) constant species (C) - those species having high constancy with presence class more than IV but low dominancy (with average species significance less than 4 );

3) important companion species (I) - those species not belonging to either of the above two categories but more or less exclusively associated with a certain association, hence characterizing it.

For each association, species that characterize the plant association are listed for different vegetation strata with abbreviations to identify which of the above three categories apply to each species within the assemblage of characteristic species.

\subsubsection{Correlation with environmental characteristics}

When the vegetation data processing was completed and plant associations were finally determined, environmental data were processed and correlated with the plant associations. Data were assembled and grouped into the recognized plant associations. Calculations were made for statistics such as means, ranges and standard deviations. These data were matched to plant associations and compared to detect significant difference between the plant associations. Environmental characteristics were also summarized for each plant association.

\subsection{Some descriptive criteria}

To have a proper understanding of the classification system and descriptions of forested plant associations, it is necessary to define some of the terminology used in this report. 

5.3.1 Hygrotope, trophotope and edatopic grid matrix.

For plant growth, the most influential soil factors are availability of moisture and nutrients. As a result of variations in topographic position, kind of parent material, soil texture, presence or absence of impermeable layers, and presence or absence of ground water channels, the availability of moisture and nutrients varies greatly within a biogeoclimatic zone. Such edaphic variability may be represented by two parameters, hygrotope and trophotope (sensu Krajina 1972).

Hygrotope is a moisture gradient and indicates magnitude of total availability of water to plants. Hygrotope was graded into nine classes as follows:

\begin{tabular}{cll} 
Class & Hygrotope & Moisture status \\
\hline 0 & very xeric & excessively drained \\
1 & xeric & very rapidly drained \\
2 & subxeric & rapidly drained \\
3 & submesic & well drained \\
4 & mesic & moderately well drained \\
5 & subhygric & imperfectly drained \\
6 & hygric & poorly drained \\
7 & subhydric & very poorly drained \\
8 & hydric & water saturated to the
\end{tabular}

Trophotope is a nutrient gradient and indicates the total availability of nutrients to plants. Trophotope was graded into six classes as follows:

\begin{tabular}{cll} 
Class & Trophotope & Nutrient status \\
\cline { 2 - 2 } & oligotrophic & very poor \\
B & submesotrophic & poor \\
C & mesotrophic & intermediate \\
D & permesotrophic & rich \\
E & subeutrophic to eutrophic & very rich \\
F & hypereutrophic & excessively rich
\end{tabular}



The hygrotope and trophotope are combined to form an edaphotope or edatope. A combination of the two parameters with nine and six classes makes 54 units within an edatope. Each unit has a potential to support one type of ecosystem or biogeocoenoses. Therefore, one biogeoclimatic zone or, more realistically, one subzone could support up to 54 kinds of ecosystems. From practical experience, a total of 54 units seems to be sufficient to accommodate all possible ecosystematic variations within a zone or subzone.

In practice, the edaphotope (hygrotope and trophotope) is assessed subjectively by integrating various factors that affect the availability of moisture and nutrients. Major factors taken into consideration include topographic position, physical and chemical properties of soils, and reaction of plants in terms of growth or vigor. Based on Pogrebniak's original concept, Krajina (1969, 1972) introduced a new method to portray edatopic characteristics on a two-dimensional co-ordinate called an edatopic grid matrix (Figure 9). This diagrammatical presentation of edatopic characteristics of ecosystems has been widely used by Krajina and co-workers.

\subsubsection{Successional stage}

Successional stages were recorded according to the following four stages:

Early stage - This is an early seral stage after some disturbance. The tree layer is barely developed with pioneer species of trees dominating. Ground vegetation includes a considerable number of species that generally have high requirements for light. During the early stage of succession, vegetation does not show much differentiation due to habitat conditions.

Intermediate state - In this stage there is a well developed tree layer consisting mostly of even-aged young trees of pioneer species. Tree species of the climax stage are already noticeable in the shrub layer and ground vegetation. Ground vegetation tends to show some features that reflect habitat conditions. 



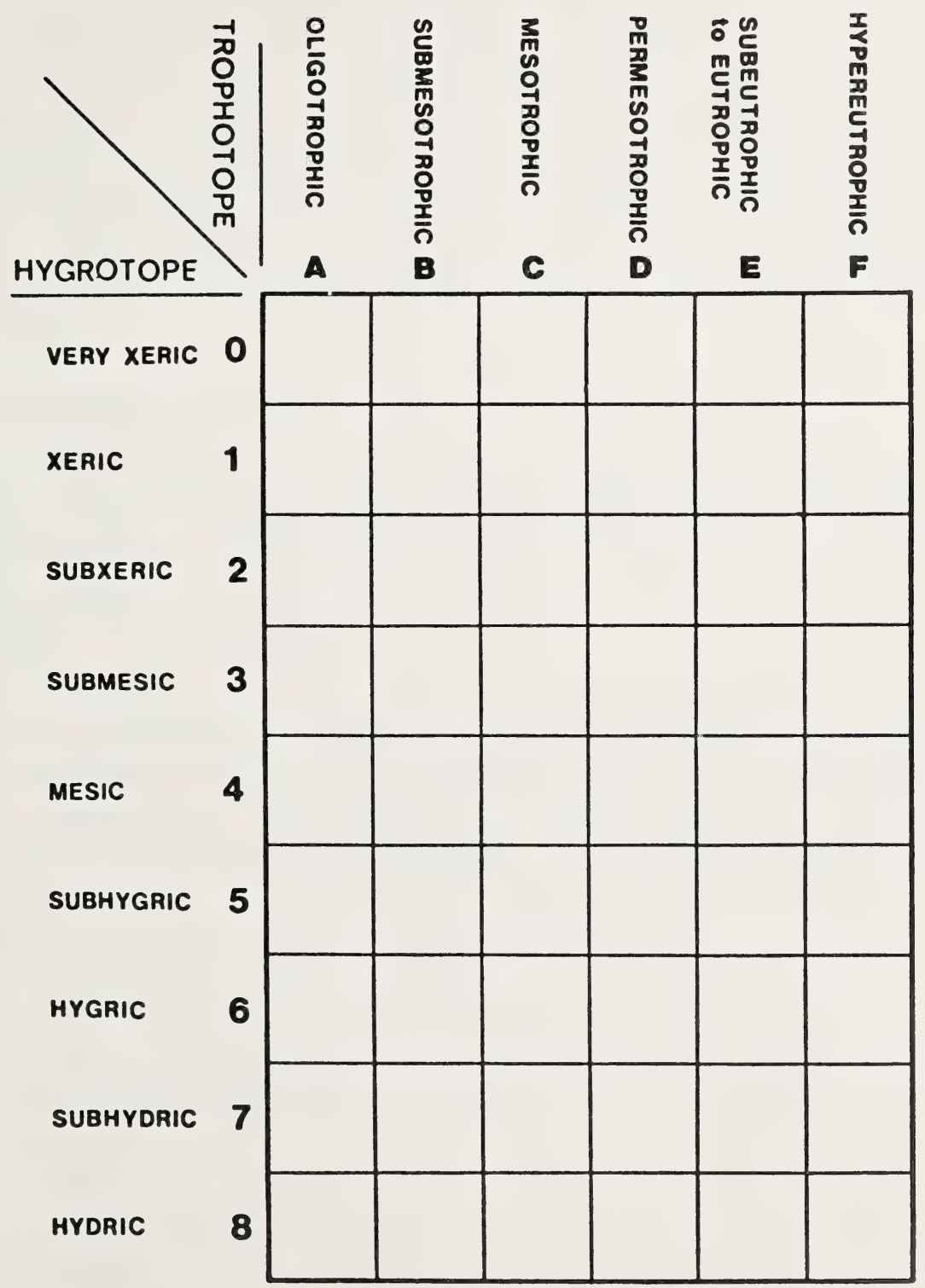

Figure 9. Hygrotope and trophotope categories arranged in an edatopic grid matrix. 

Advanced stage - This is a late stage of succession in which the tree layer consists of a mixture of pioneer species and climax species. Regeneration of climax tree species is common. Ground vegetation shows a strong relationship with habitat conditions.

Mature stage - This is a climax stage of succession in which the tree layer consists almost exclusively of climax species with a rare presence of pioneer species of trees as remnants of former stages. Regeneration of climax species of trees is present in all layers. Ground vegetation shows a strong relationship with habitat conditions.

\subsubsection{Soil nomenclature}

In this report, soil descriptions and nomenclature follow the system proposed by the Canadian Soil Survey Committee (1978).

\subsubsection{Forestry characteristics}

The mensurational parameters used to characterize the forest stands of each association were: total stem volume of standing trees $\left(\mathrm{m}^{3} / \mathrm{ha}\right)$; percentage of total stem volume partitioned by species; number of trees per hectare; average height of dominant and co-dominant trees; average height of forest canopy; average stand age; average mean annual increment ( $\left.\mathrm{m}^{3} / \mathrm{ha}\right)$; and site index (height (m) of dominant and co-dominant trees at age 70). Average stand age was based on total age, not breast height age and was computed by diameter classes for each species and weighted by the number of core samples in each species. 



\section{DESCRIPTION OF THE FORESTED PLANT ASSOCIATIONS}

\subsection{Overview}

A total of eight forested plant associations were recognized in the study area (Table 1). Of these, six associations represent ecosystems of the lower subzone of the northern subalpine zone, and two associations represent ecosystems of the upper subzone. The lower and upper subzones are described separately in sections 6.2 and 6.3 , respectively.

It should be noted that the eight associations described in this study do not represent all the possible plant associations in the study area. Those described here are only those of well developed forest ecosystems. There are numerous kinds of non-forested associations in the area that are not included in this report.

Forested plant associations are described in terms of general environmental characteristics and patterns of occurrence, vegetation structure, soil characteristics and forestry characteristics. Diagrams to demonstrate some diagnostic features of the associations are provided in later sections and in Figures 44 to 50 of this report.

6.2 Plant associations of the lower subzone.

In the lower subzone, the following six forested plant associations were recognized and described:

1. Pinus contorta - Juniperus communis - Elymus innovatus association (the pine-Elymus or Elymus association)

2. Pinus contorta - Shepherdia canadensis - moss association (the pine-Shepherdia or Shepherdia association)

3. Pinus contorta - Rhododendron - Rubus pedatus association (the pine-Rhododendron or Rhododendron association)

4. Picea engelmannil/Abies lasiocarpa - Vaccinium membranaceum - moss association (the spruce/fir-moss or moss association) 



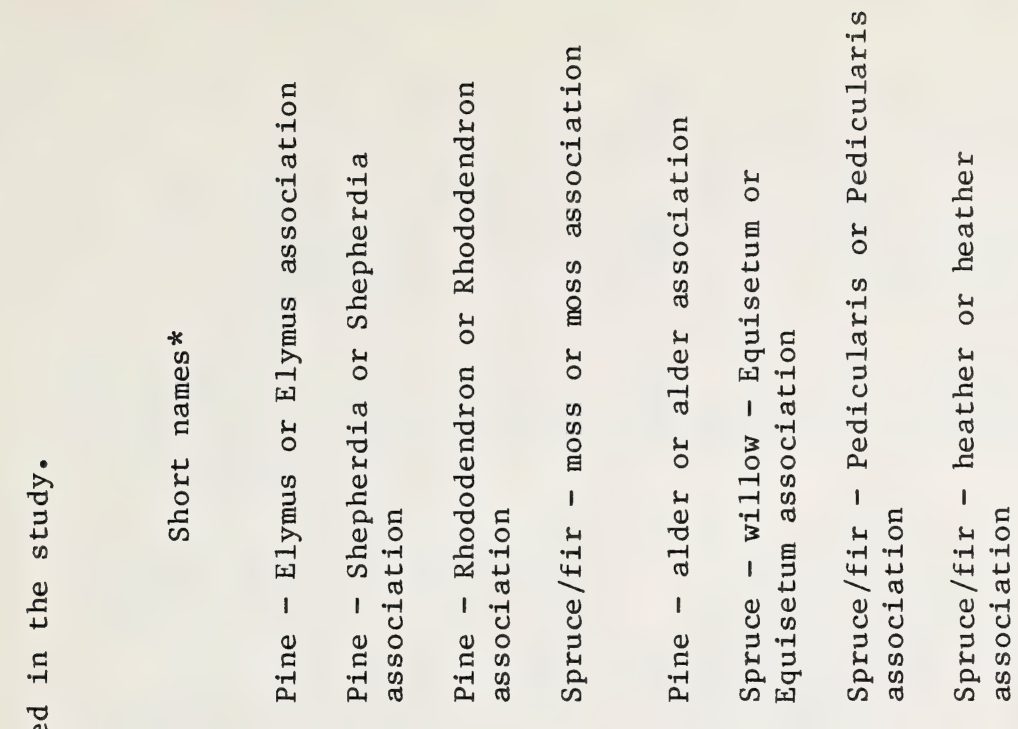

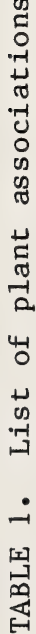

ב⿱艹

$\rightarrow \quad z$

罗

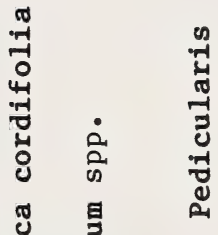

$\stackrel{+}{\ddot{2}}$

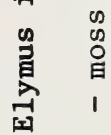

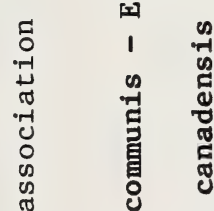

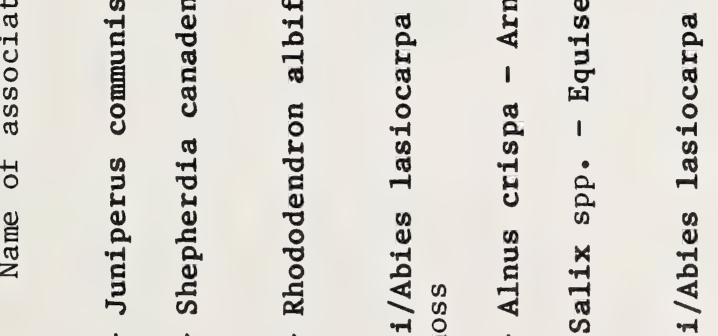

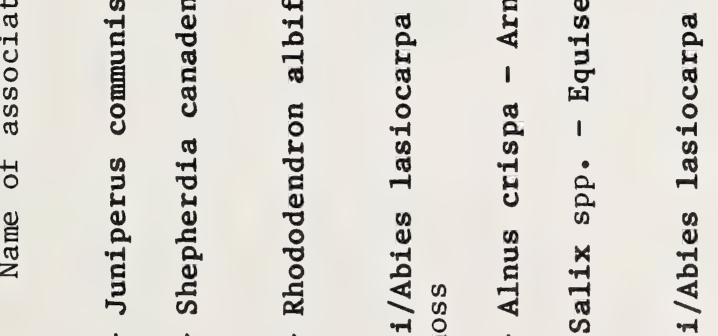

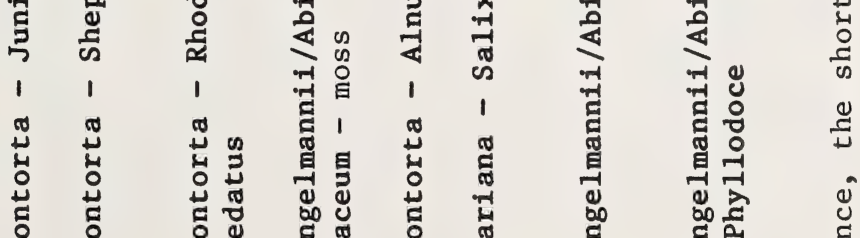

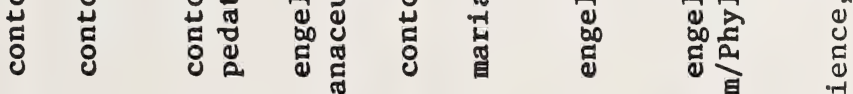

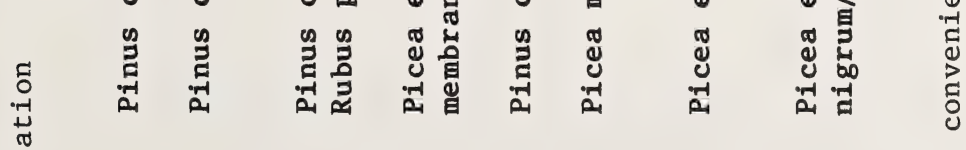

ป⿱艹

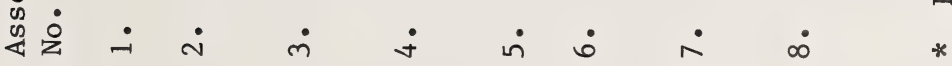



5. Pinus contorta - Alnus crispa - Arnica cordifolia association (the pine-alder or alder association)

6. Picea mariana - Salix spp. - Equisetum spp. association (the spruce-willow-Equisetum or Equisetum association)

6.2.1 Pinus contorta - Juniperus communis - Elymus innovatus association

\subsubsection{General Description}

The Elymus association represents xeric to subxeric ecosystems of the lower subzone (Figure 10). It occurs on predominantly south-facing slopes and on well drained habitats with coarse substrates. It tends to prefer calcareous parent material. This association is, however, relatively uncommon in the study area. Eight sample plots were established to represent this association.

The tree layer consists mostly of even-aged Pinus contorta occasionally mixed with Picea glauca or hybrid swarms of Picea glauca and Picea engelmannii as subordinate trees (Figure 11). The shrub layer is moderately well developed with a comparatively high coverage of Rosa acicularis and Shepherdia canadensis, with lesser amounts of Juniperus communis. Development of the herb layer is moderate, with major species being Linnaea borealis, Elymus innovatus, Pyrola secunda, Zygadenus elegans, Arnica cordifolia and Fragaria virginiana. The moss layer is rather weakly developed although Pleurozium schreberi, Pohlia nutans, Cladonia coccifera and Hylocomium splendens are relatively constant.

Soils are generally coarse-textured and are derived mostly from glacial till and some colluvial material (Figure 12). Soils are mostly loam, silt loam or clay loam (Figure 13). The L-H horizon is characteristically thin, presumably reflecting a low rate of litter supply, while the decomposition rate is high. Base status of the 



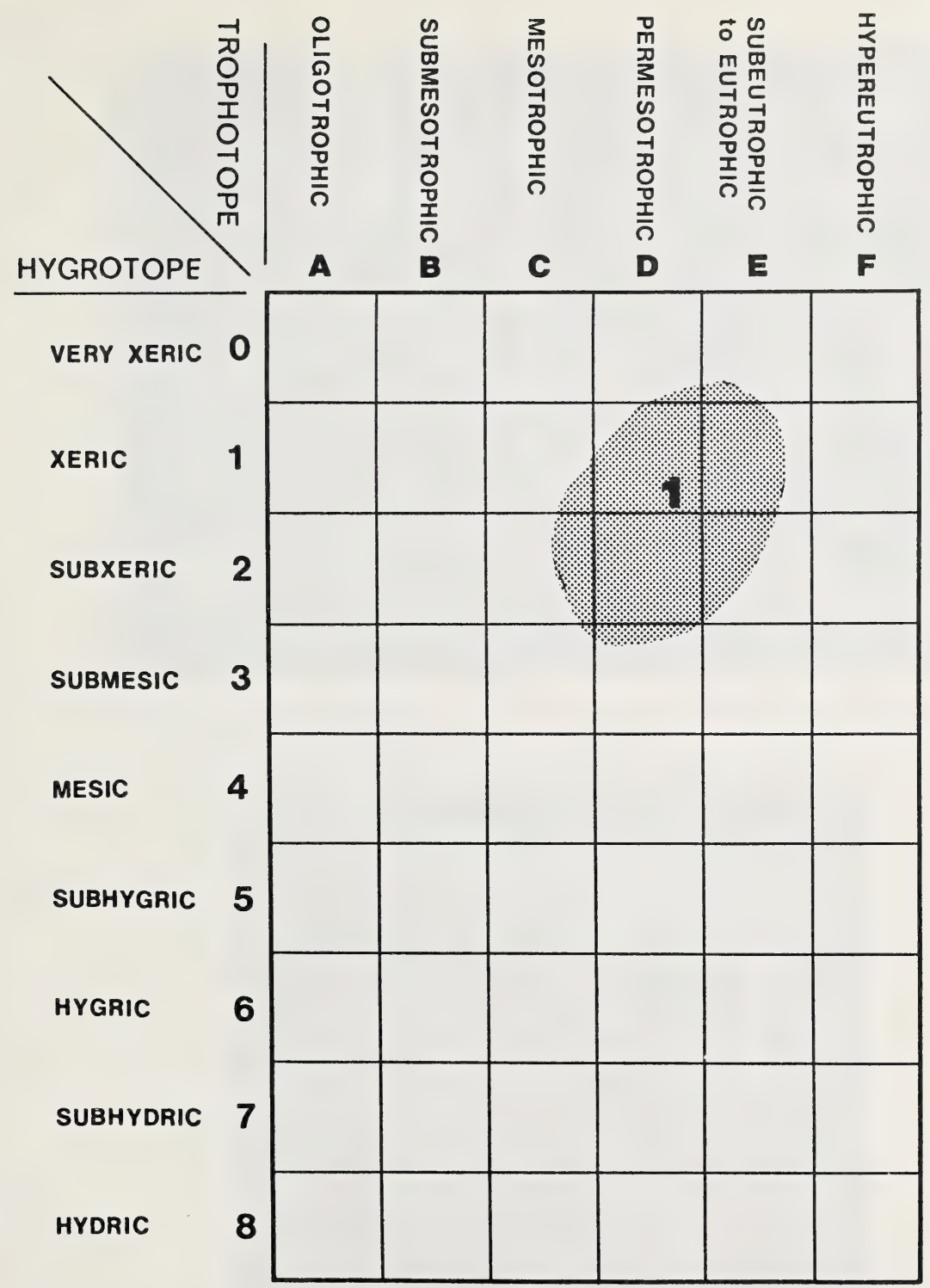

Figure 10. Edatopic position of the pine-Elymus association 



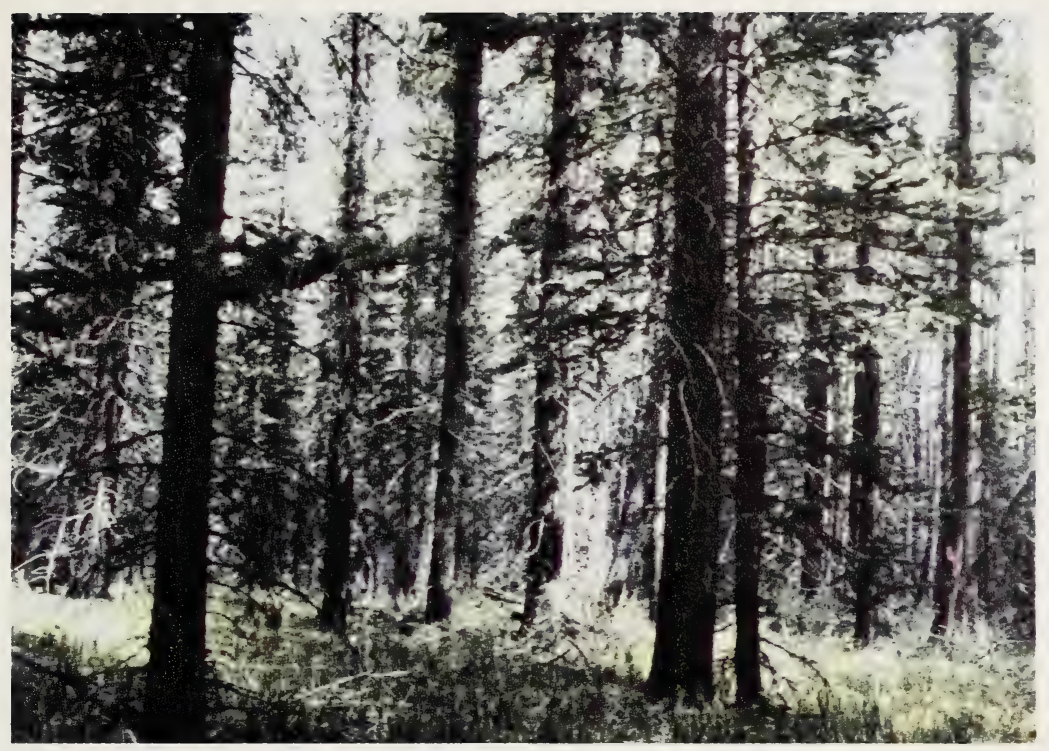

Figure 11. A forest stand of the pine-Elymus association

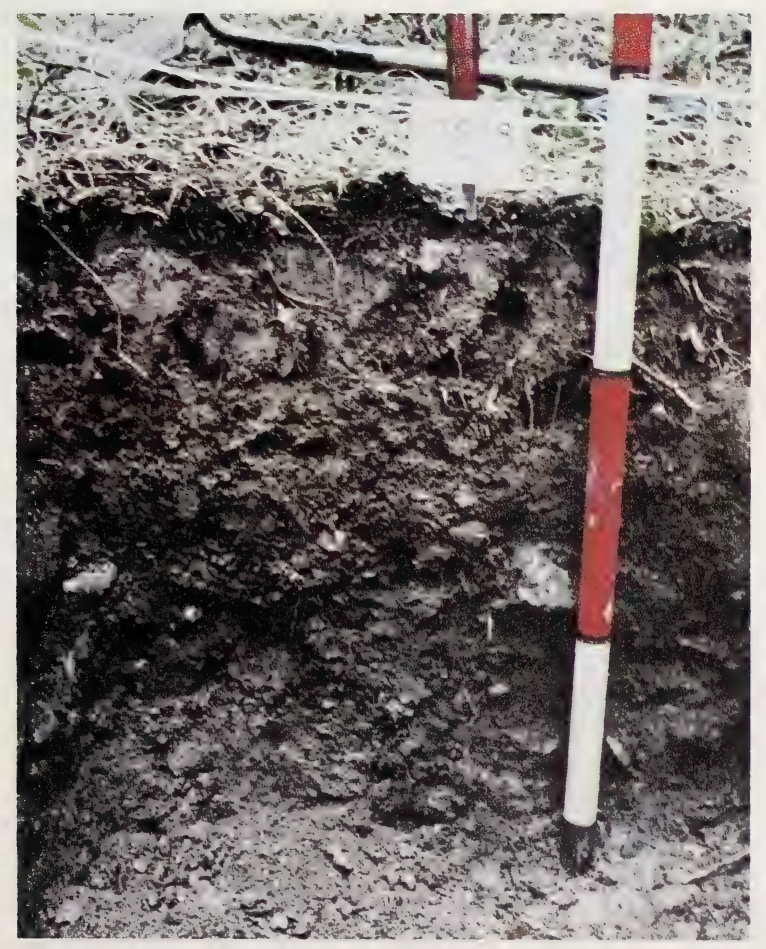

Figure 12. Soil profile of the pine-Elymus association 



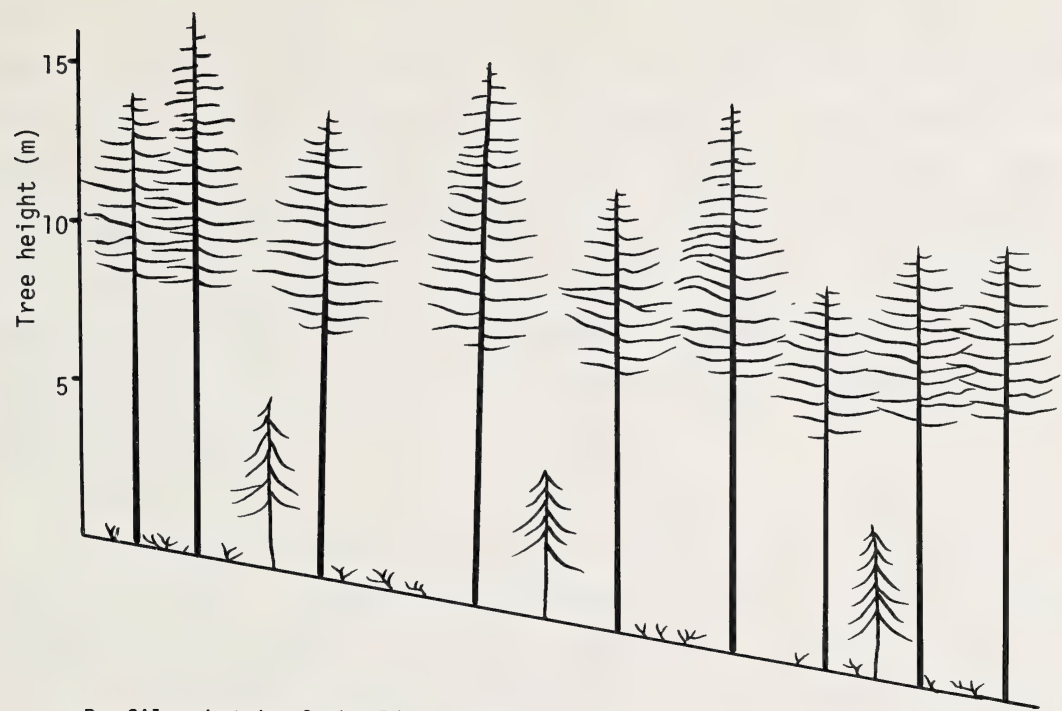

Profile sketch of the Pine - Elymus association

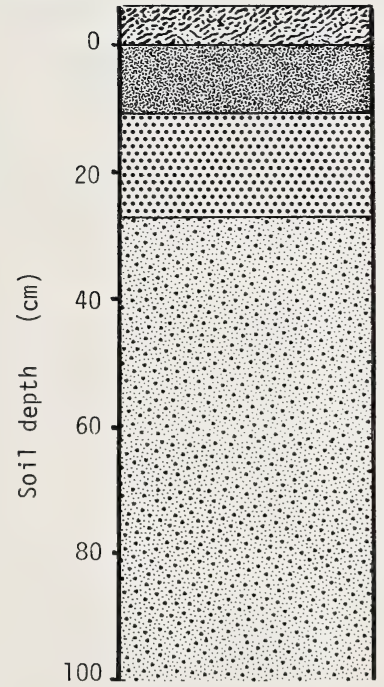

Representative soil profile

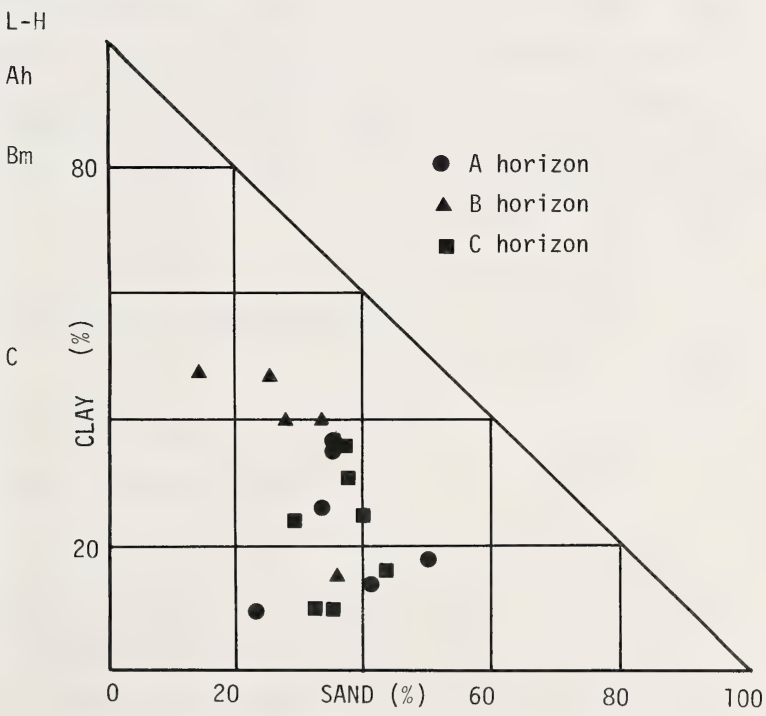

Particle size distribution of the samples representing different horizons 

soils is very high; base saturation was found to be 99, 130, 96 and $219 \%$, on the average, for the L-H, A, B and C horizons, respectively. These values are the highest among the eight associations described in this study and can probably be attributed to a low rate of leaching on the south-facing slopes and partly to the calcareous nature of the parent materials. Values for $\mathrm{pH}$ are also high as they were 5.4, 5.6, 5.5 and 7.1 , on average, for the $\mathrm{L}-\mathrm{H}, \mathrm{A}, \mathrm{B}$, and $\mathrm{C}$ horizons, respectively. The $\mathrm{C} / \mathrm{N}$ ratio is medium ranged. The amount of available phosphorus is fairly high in the L-H horizon, but is low in the mineral horizons (Table 2).

Forest productivity is fairly good as total volume of standing stems attains an average of $301.1 \mathrm{~m}^{3} /$ ha. Lodgepole pine contributes one-third of the volume with the remainder from white spruce or from white spruce-Engelmann spruce hybrids. Average height of dominant and co-dominant lodgepole pine is $16.8 \mathrm{~m}$, average height of the forest canopy is $14.8 \mathrm{~m}$, and average age of dominant trees is 134 years. Mean annual increment on the average is $2.40 \mathrm{~m}^{3} / \mathrm{ha}$. Site index of lodgepole pine is $14.2 \mathrm{~m} / 70$ years and that of Engelmann spruce is $14.5 \mathrm{~m} / 70$ years.

6.2.1.2 Characteristic combination of species

$\begin{array}{ll}\text { Tree layer } & \text { Pinus contorta (CD) } \\ \text { Shrub layer } & \text { Rosa acicularis (CD) } \\ & \text { Juniperus communis (C) } \\ & \text { Shepherdia canadensis (C) } \\ \text { Herb layer } & \text { Elymus innovatus (CD) } \\ & \text { Linnaea borealis (C) } \\ & \text { Pyrola secunda (C) } \\ & \text { Zygadenus elegans (C) } \\ & \text { Arnica cordifolia (C) } \\ & \text { Fragaria virginiana (C) } \\ & \text { Hedysarum alpinum (I) } \\ & \text { Arctostaphylos uva-ursi (I) } \\ & \text { Vaccinium caespitosum (I) }\end{array}$





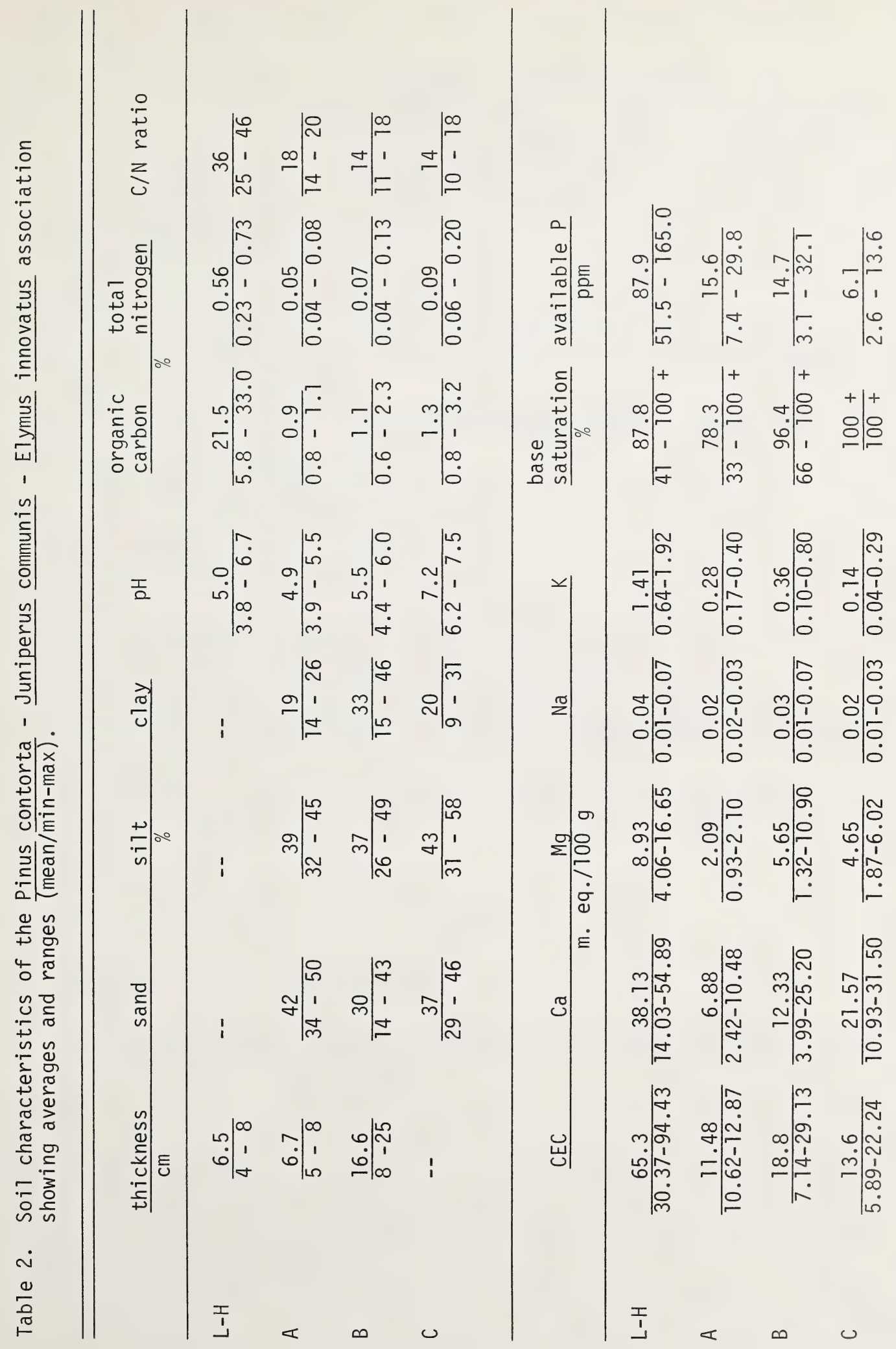



Moss layer

Pleurozium schreberi (C)

Pohlia nutans (C)

Hylocomium splendens (C)

Cladonia coccifera (C)

\subsubsection{Site characteristics}

- topographic position: upper to middle positions of prevailingly south-facing slopes, or on well drained habitats of gentle slopes

- altitude range: from approximately 1,000 to $1,700 \mathrm{~m}$ as 1 .

- slope: level to $26^{\circ}$

- aspect: (NNE)* - SE - S - W

\subsubsection{Soil characteristics}

- soil classification: Orthic Regosol, Orthic Gray Luvisol, Orthic Eutric Brunisol and Orthic Dystric Brunisol

- soil moisture regime (hygrotope): xeric to subxeric (1-2)

- soil nutrient regime (trophotope): permesotrophic to eutrophic (D-E)

- depth to groundwater table: no water table detected to a depth of $100 \mathrm{~cm}$

6.2.1.5 Successional stage: intermediate

6.2.1.6 Forestry characteristics

- total stem volume of standing trees, average and range: 301.0 $(203.4-386.9) \mathrm{m}^{3} / \mathrm{ha}$

* a bracketed aspect indicates uncommon occurrences on aspects facing in that direction. 

- percentage of total stem volume partitioned by species:

lodgepole pine - $66.7 \%$

white spruce including Engelmann spruce - $33.3 \%$

- regeneration: moderate

- regeneration by: mostly hybridized white spruce

- number of trees per hectare: 1,773

- average stand age: 134 years

- average height of dominant and co-dominant trees:

lodgepole pine, $16.8 \mathrm{~m}$

- average height of forest canopy: $14.8 \mathrm{~m}$

- average mean annual increment: $2.40 \mathrm{~m}^{3} / \mathrm{ha}$

- site index: lodgepole pine, $14.2 \mathrm{~m} / 70 \mathrm{yr}$

Engelmann spruce, $14.5 \mathrm{~m} / 70 \mathrm{yr}$

\subsubsection{Pinus contorta - Shepherdia canadensis - moss association}

\subsubsection{General description}

The Shepherdia association represents subxeric to submesic ecosystems (Figure 14). Its occurrence is, however, rather rare in the study area. Only two sample plots were obtained for this association. It becomes more common towards the southern part of the study area (Walker et al. 1980). Because of the limited number of samples, the following description is provisional.

This association develops on well to moderately drained habitats of gently sloping landforms, mostly of glacial till origin but with some of fluvial or lacustrine origin. Slopes supporting this association tend to face south.

The tree layer consists mainly of even-aged Pinus contorta (Figure 15). The frequent presence of Picea glauca Picea engelmannil hybrids, together with Picea mariana in the subordinate tree layer, suggests an intermediate stage of vegetation succession. The shrub layer is well developed and is dominated by Shepherdia canadensis, with lesser amounts of Rosa acicularis, 



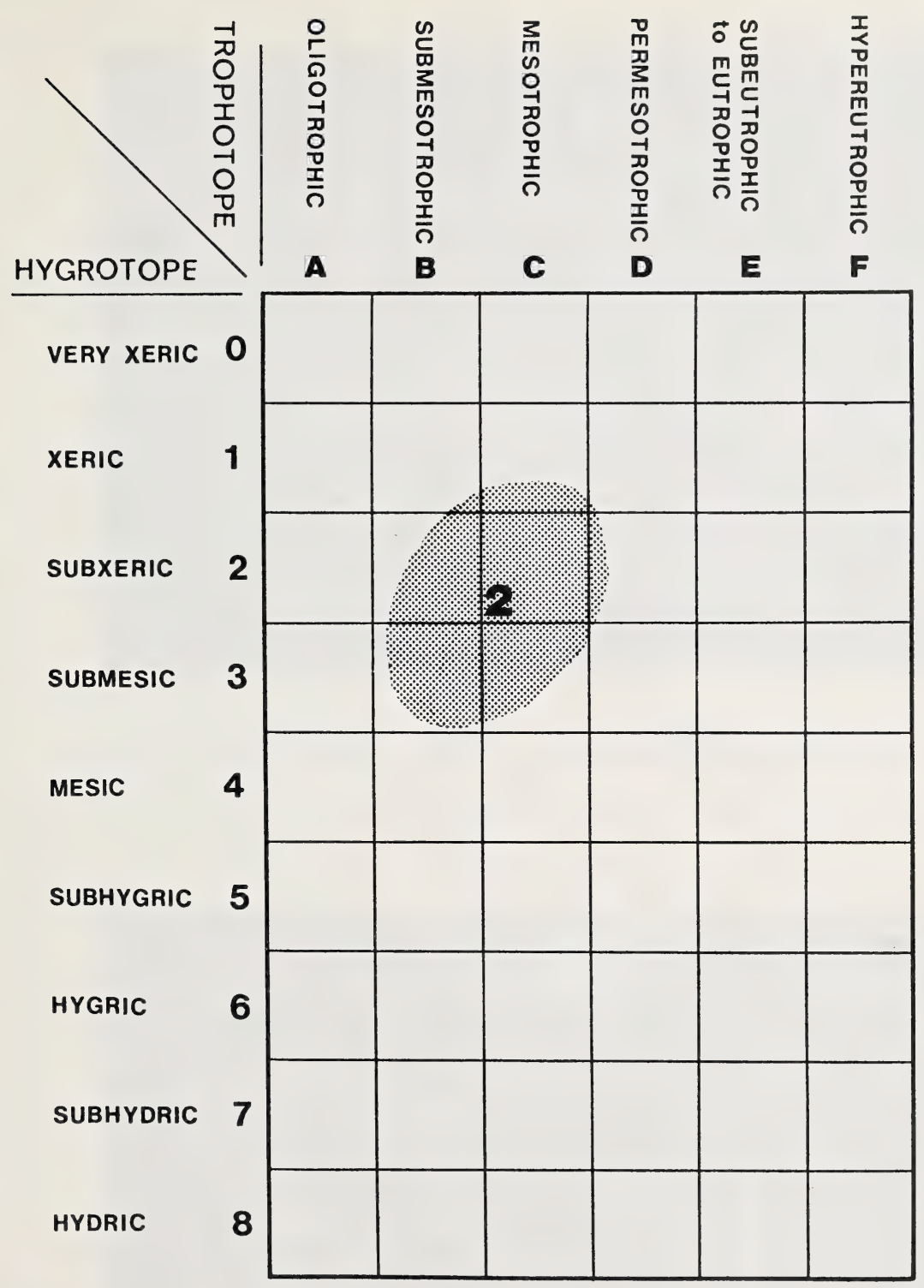

Figure 14. Edatopic position of the pine-Shepherdia association 



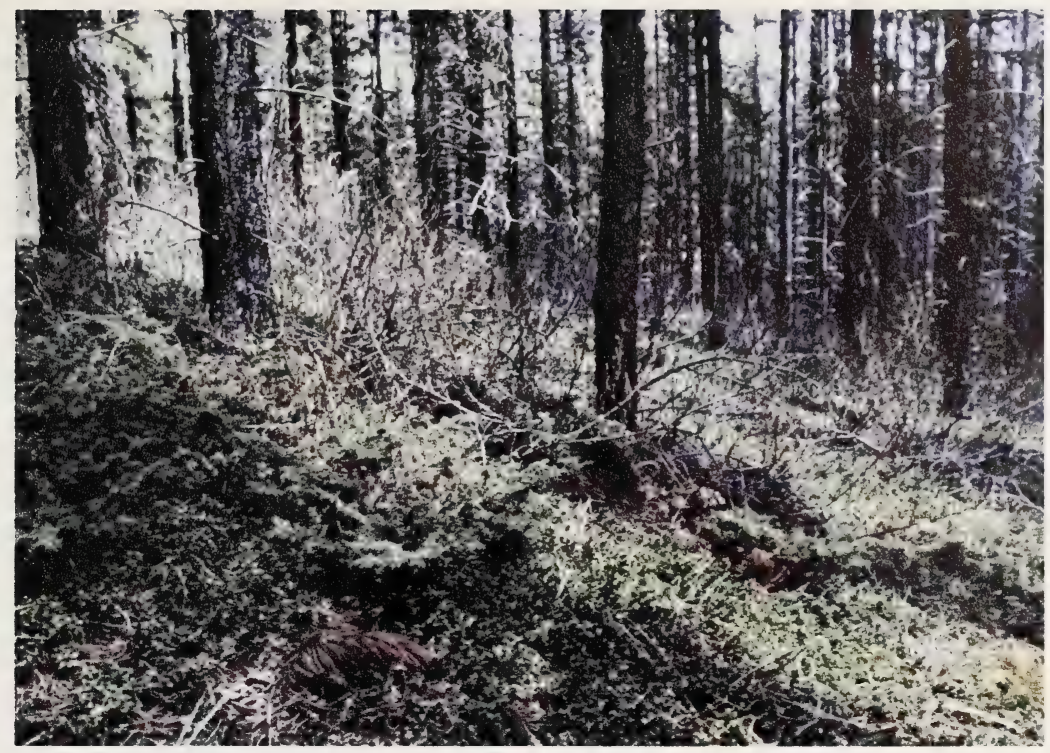

Figure 15. A forest stand of the pine-Shepherdia association

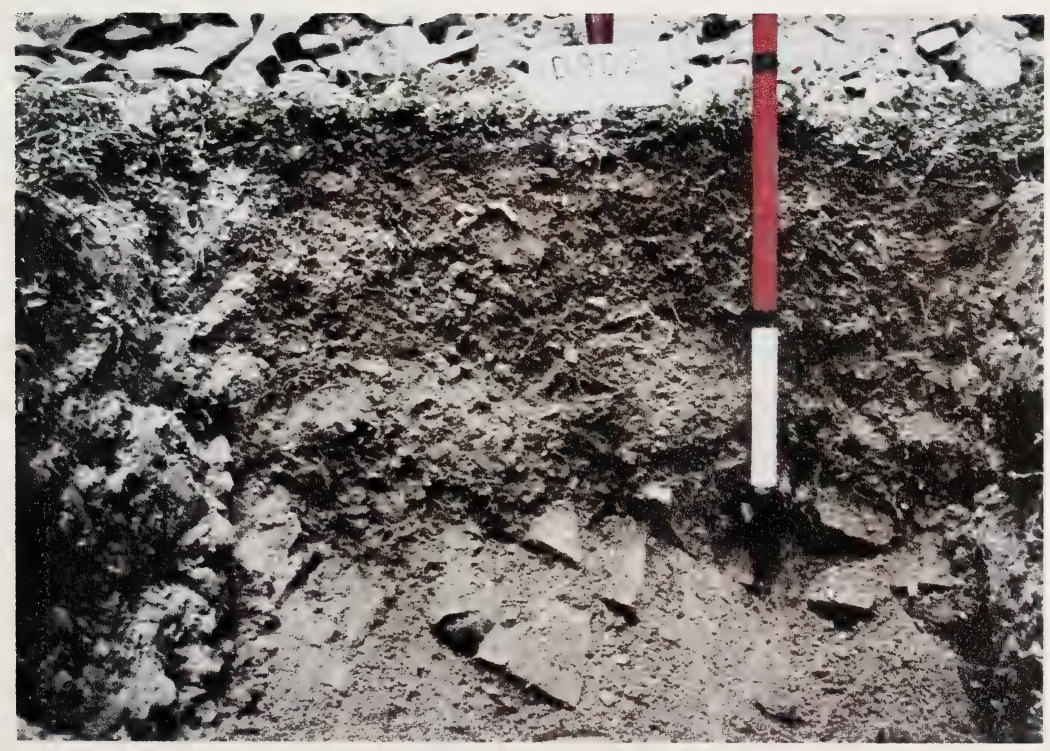

Figure 16. Soil profile of the pine-Shepherdia association 



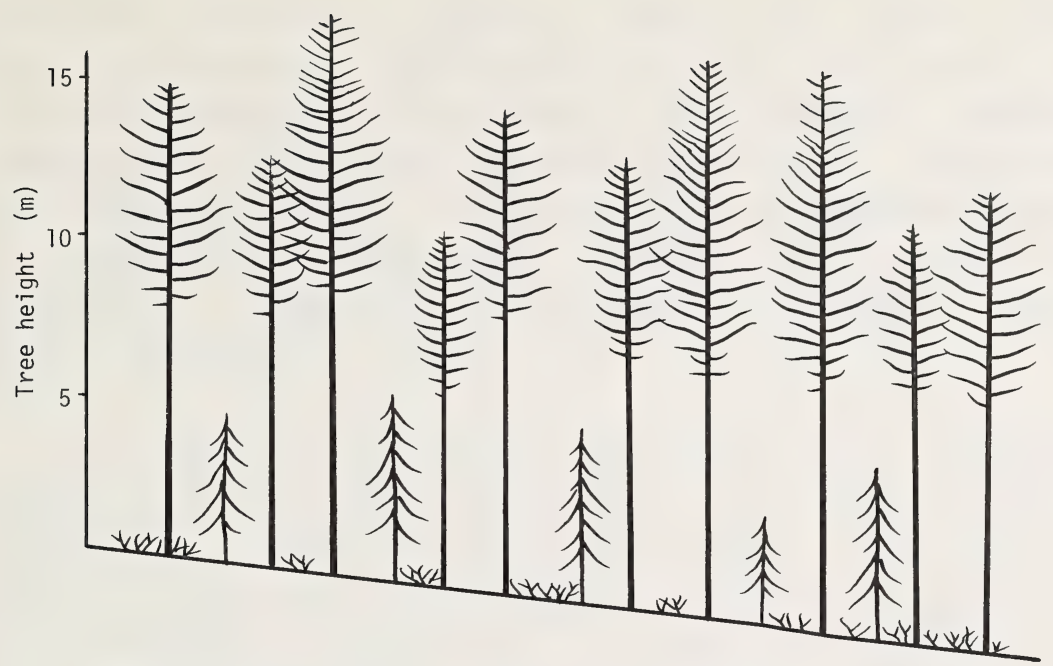

Profile sketch of the Pine - Shepherdia association
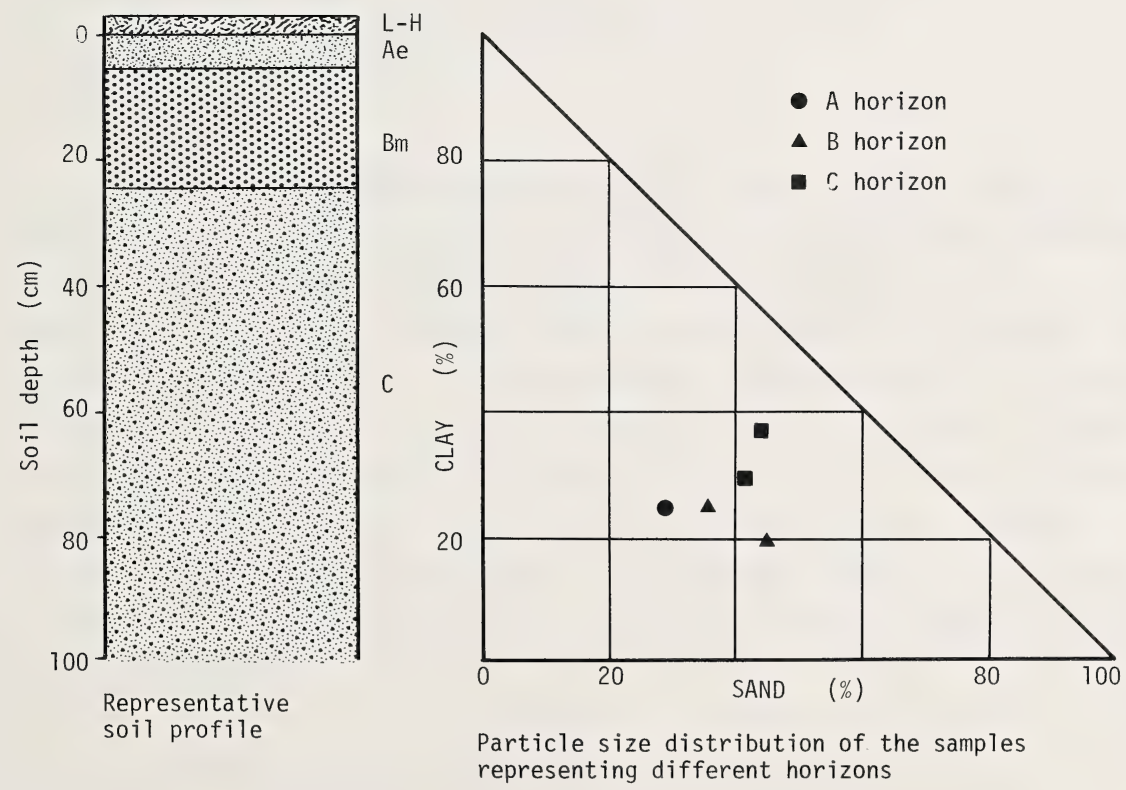

Figure 17. Vegetation and soil profiles and soil particle size distribution of the pine-Shepherdia association 

Juniperus communis, Spiraea lucida and Ledum groenlandicum. The herb layer is moderately developed, with major constituents including Vaccinium vitis-idaea, Arctostaphylos uva-ursi, Elymus innovatus, Linnaeae borealis, Arnica cordifolia, Lathyrus ochroleucus and Zygadenus elegans. The moss layer is moderately developed and is dominated by Pleurozium schreberi with lesser coverage by Hylocomium splendens, Peltigera aphthosa and Ptilium crista-castrensis.

Soils, mostly derived from glacial till, are medium-textured (Figure 16); most samples are loam and silt loam with some clay loam (Figure 17). Development of horizons is weak. Base status of soils is moderate as base saturations average $63,86,64$ and $69 \%$ for the L-H, A, $\mathrm{B}$ and $\mathrm{C}$ horizons, respectively. The $\mathrm{pH}$ is also somewhat moderate, with averages of $4.6,4.9,4.8$ and 4.9 for the L-H, A, B and C horizons, respectively. The $\mathrm{C} / \mathrm{N}$ ratio is characteristically low in this association. The amount of available phosphorus is moderate to low (Table 3).

Forest productivity is fairly good in this association, with site index of lodgepole pine reaching $15.0 \mathrm{~m} / 70$ years, although total volume of standing stems is low $\left(264.7 \mathrm{~m}^{3} / \mathrm{ha}\right)$. Such a low figure seems to be an underestimate and probably does not represent potential forest productivity of the association. This anomaly is thought to be a result of the small number of sample plots which were not adequate to cover the normal range of productivity. Mean annual increment was measured as $2.66 \mathrm{~m}^{3} / \mathrm{ha}$ which is the second highest amongst the eight forested plant associations. Average height of dominant and co-dominant lodgepole pine is $17.1 \mathrm{~m}$ and average height of the forest canopy is $15.1 \mathrm{~m}$.

6.2.2.2 Characteristic combination of species

$\begin{array}{ll}\text { Tree layer } & \text { Pinus contorta (CD) } \\ & \text { Picea engelmannil (C) } \\ \text { Shrub layer } & \text { Shepherdia canadensis (CD) } \\ & \text { Rosa acicularis (C) } \\ & \text { Juniperus communis (I) } \\ & \text { Spiraea lucida (I) }\end{array}$





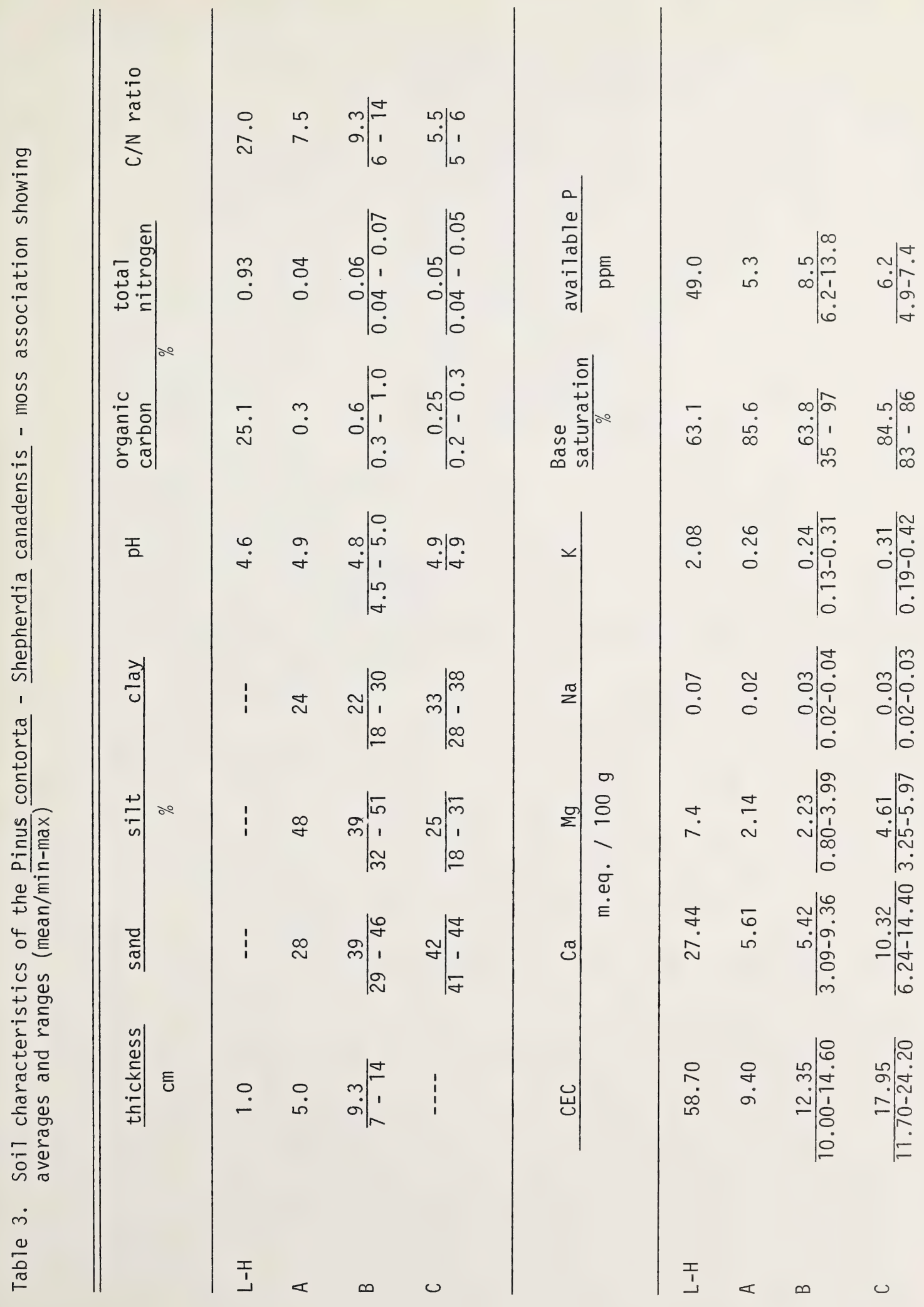





$\begin{array}{ll}\text { Herb layer } & \text { Vaccinium vitis-idaea (CD) } \\ & \text { Arctostaphylos uva-ursi (CD) } \\ & \text { Elymus innovatus (C) } \\ & \text { Linnaea borealis (C) } \\ & \text { Arnica cordifolia (C) } \\ & \text { Lathyrus ochroleucus (C) } \\ & \text { Zygadenus elegans (C) } \\ & \text { Pleurozium schreberi (CD) } \\ \text { Moss layer } & \text { Hylocomium splendens (CD) } \\ & \text { Peltigera aphthosa (C) } \\ & \text { Peltigera malacea (C) } \\ & \text { Ptilium crista-castrensis (C) }\end{array}$

6.2.2.3 Site characteristics

- topographic position: middle slope of gently sloping mountains and hills

- altitude range: from approximately 1,300 to $1,600 \mathrm{~m}$ as 1 .

- slope: leve1 to $15^{\circ}$

- aspect: SE

\subsubsection{Soil characteristics}

- soil classification: Orthic Dystric Brunisol

- soil moisture regime (hygrotope): subxeric to submesic (2-3)

- soil nutrient regime (trophotope): submesotrophic to mesotrophic $(B-C)$

- depth to groundwater table: no water table detected to a depth of $100 \mathrm{~cm}$

6.2.2.5 Successional stage: intermediate

6.2.2.6 Forestry characteristics

- total stem volume of standing trees, average and range: 264.7

$$
(190.7-338.7) \mathrm{m}^{3} / \mathrm{ha}
$$



- percentage of the total stem volume partitioned by species:

lodgepole pine - $95.4 \%$

trembling aspen $-4.6 \%$

- regeneration: moderate

- regeneration by: mostly white spruce, including white spruceEngelmann spruce hybrids, and black spruce

- number of trees/ha: 1,116

- average stand age: 92 years

- average height of dominant and co-dominant trees:

lodgepole pine, $17.1 \mathrm{~m}$

- average height of forest canopy: $15.1 \mathrm{~m}$

- average mean annual increment: $2.66 \mathrm{~m}^{3} / \mathrm{ha}$

- site index: Lodgepole pine, $15.0 \mathrm{~m} / 70 \mathrm{yr}$

\subsubsection{Pinus contorta - Rhododendron albiflorum - Rubus pedatus association}

6.2.3.1 General description

The Rhododendron association represents submesic to mesic ecosystems that are of poor nutritional status (Figure 18). It is relatively common in the study area, mainly on gentle slopes of generally northerly aspects. It occurs at relatively high elevations up to $2,000 \mathrm{~m}$ asl. in habitats which are protected by snow. Ten sample plots were obtained to represent this association.

The tree layer consists predominantly of even-aged Pinus contorta, accompanied by Abies lasiocarpa and Picea mariana in the subordinate tree layer, indicating an intermediate to early advanced successional stage. The shrub layer is very well developed and is characterized by Rhododendron albiflorum (Figure 19), followed by Vaccinium membranaceum and Ledum groenlandicum. The herb layer is moderately developed. Cornus canadensis is the dominant of the herb layer, but Lycopodium annotinum, Rubus pedatus and Vaccinium vitis-idaea also show a high constancy. Other major constituents include Empetrum nigrum, Linnaea borealis, Pyrola 



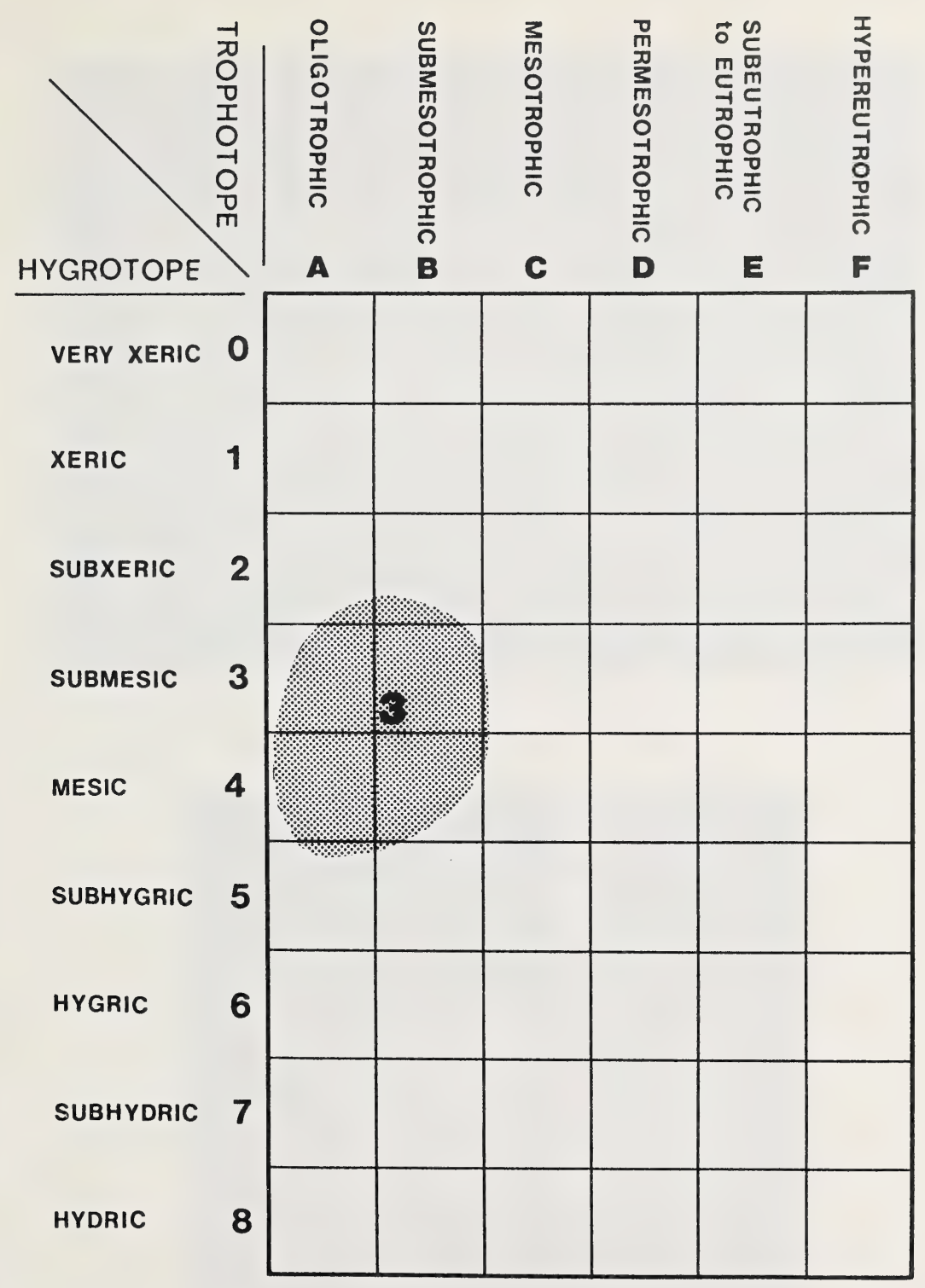

Figure 18. Edatopic position of the pine-Rhododendron association 



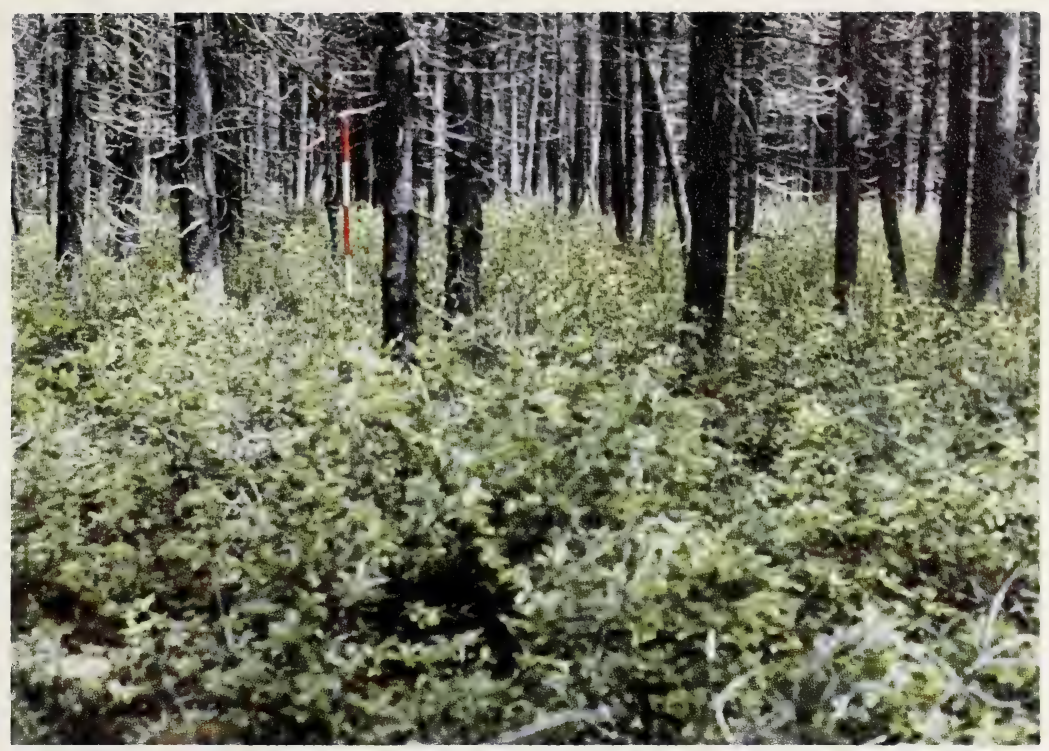

Figure 19. A forest stand of the pine-Rhododendron association

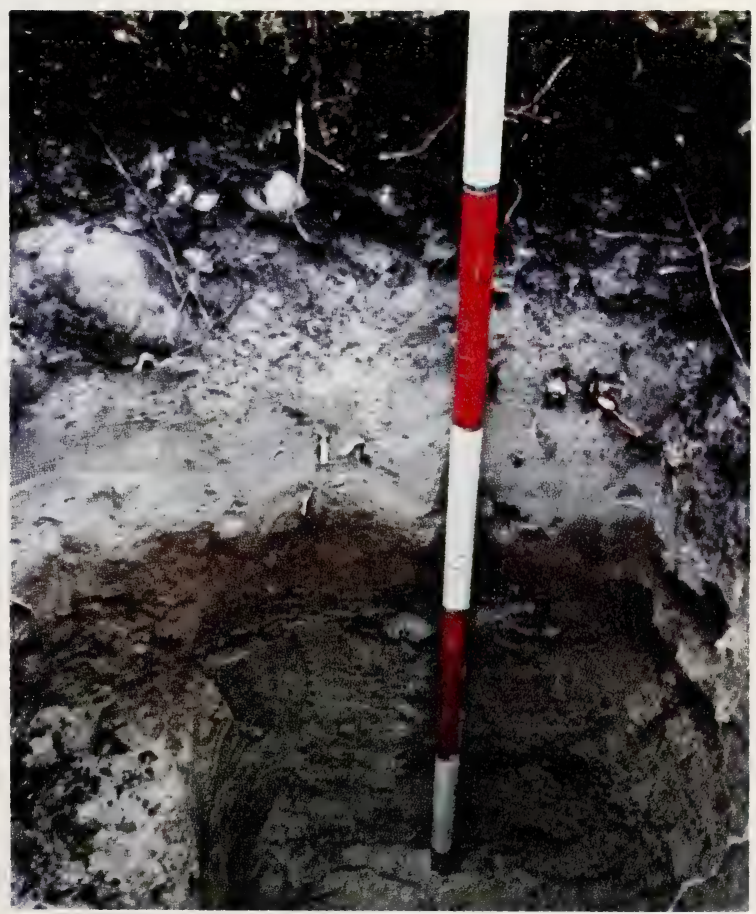

Figure 20. Soil profile of the pine-Rhododendron association 



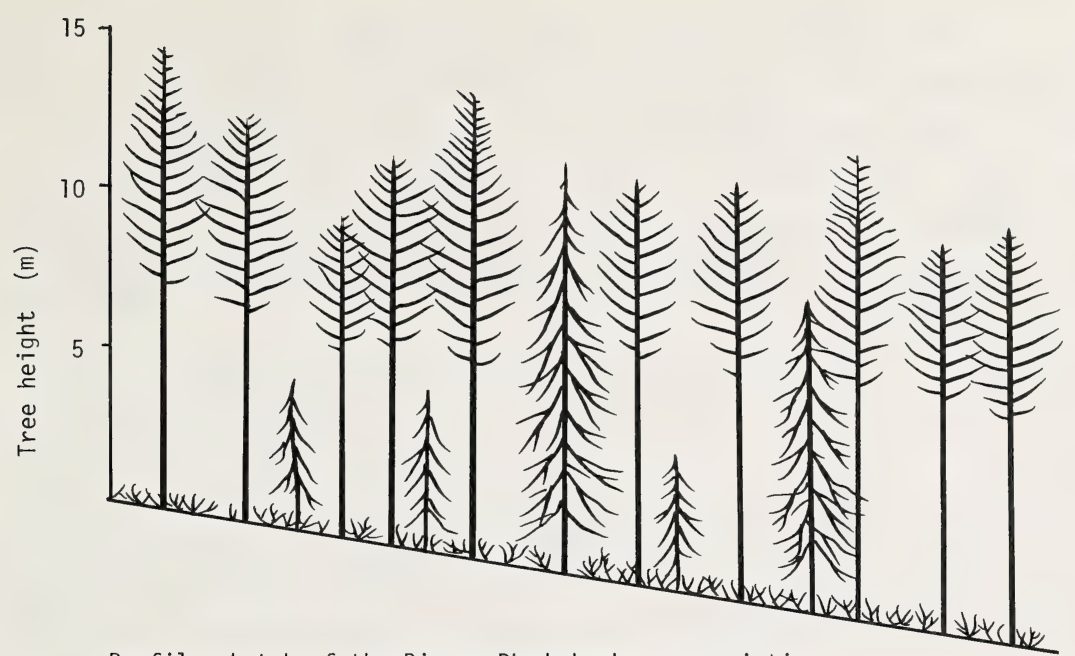

Profile sketch of the Pine - Rhododendron association
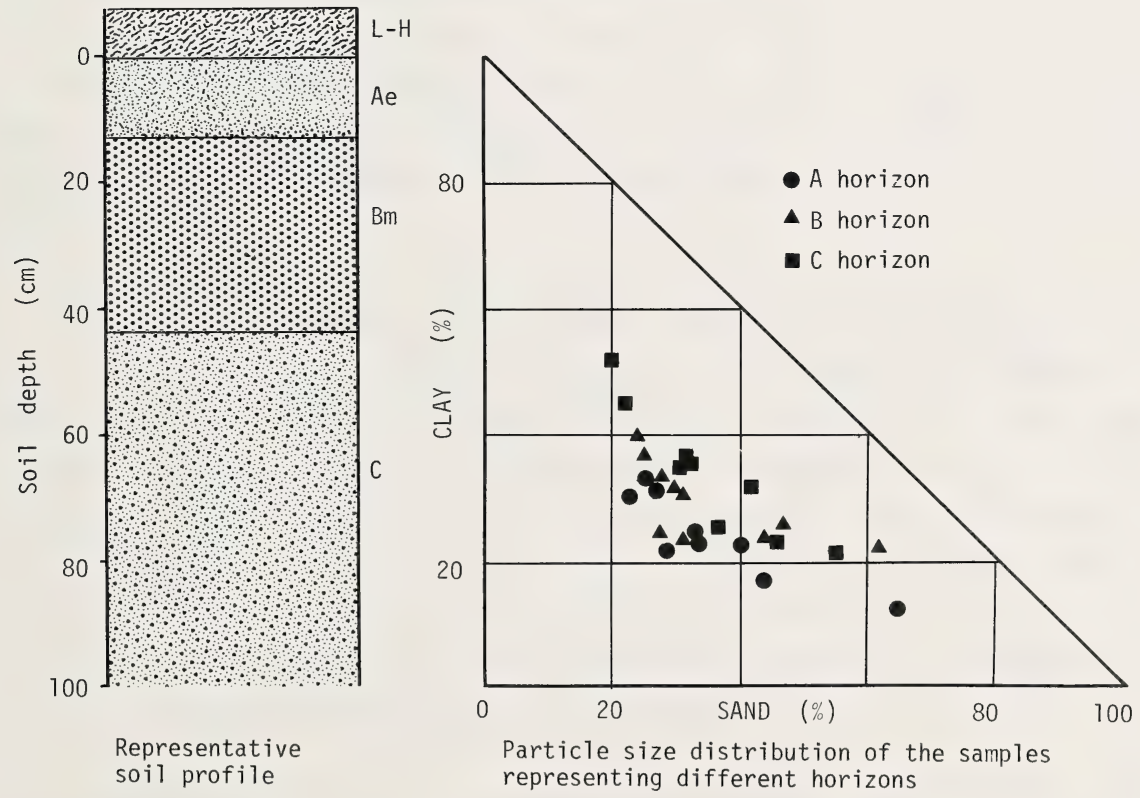

Figure 21. Vegetation and soil profiles and soil particle size distribution of the pine-Rhododendron association 

secunda, Arnica latifolia and Arnica cordifolia. The moss layer is very well developed, forming a dense moss carpet on the forest floor. Pleurozium schreberi is the dominant moss, followed by Dicranum fuscesens, Ptilium crista castrensis and Hylocomium splendens. Lichens such as Peltigera aphthosa, Cladonia coniocraea and Cladonia gonecha are common in this layer.

Soils have developed on glacial till and are moderately fine-textured (Figure 20). Most of the samples were clay loam, loam and clay, with some sandy loam and sandy clay loam (Figure 21). Base status of soils in this association is characteristically low, with base saturation averaging 17, 46, 21 and $67 \%$ for the L-H, A, B and C horizons, respectively. Reflecting this low base status, $\mathrm{pH}$ values are also quite low with averages of $3.3,3.7,3.9$ and 4.6 for the $\mathrm{L}-\mathrm{H}, \mathrm{A}, \mathrm{B}$ and $\mathrm{C}$ horizons, respectively. These $\mathrm{pH}$ values are the lowest of all the associations described in this study. The $\mathrm{C} / \mathrm{N}$ ratio varies over a broad range (Table 4). The amount of available phosphorus is higher in soils of this association than in any other association described in the study area.

Forest productivity of this association is medium, with total stem volume averaging $297.9 \mathrm{~m}^{3} / \mathrm{ha}$, made up mainly of lodgepole pine, with lesser amounts of black spruce, subalpine fir and Engelmann spruce. Average height of dominant and co-dominant trees is $14.3 \mathrm{~m}$ for lodgepole pine and $12.9 \mathrm{~m}$ for subalpine fir and Engelmann spruce; average height of the forest canopy is $13.2 \mathrm{~m}$. Average mean annual increment is $2.18 \mathrm{~m}^{3} / \mathrm{ha}$. Site index of lodgepole pine is $11.3 \mathrm{~m} / 70$ years, and for black spruce, Engelmann spruce and subalpine fir is $10.5,8.0$ and $8.0 \mathrm{~m} / 70$ years, respectively.

\subsubsection{Characteristic combination of species}

$\begin{array}{ll}\text { Tree layer } & \text { Pinus contorta (CD) } \\ & \text { Abies lasiocarpa (I) } \\ & \text { Picea engelmannii (I) } \\ & \text { Rhododendron albiflorum CD) } \\ \text { Shrub layer } & \text { Laccinium membranaceum (CD) } \\ & \text { Ledum groenlandicum (C) }\end{array}$





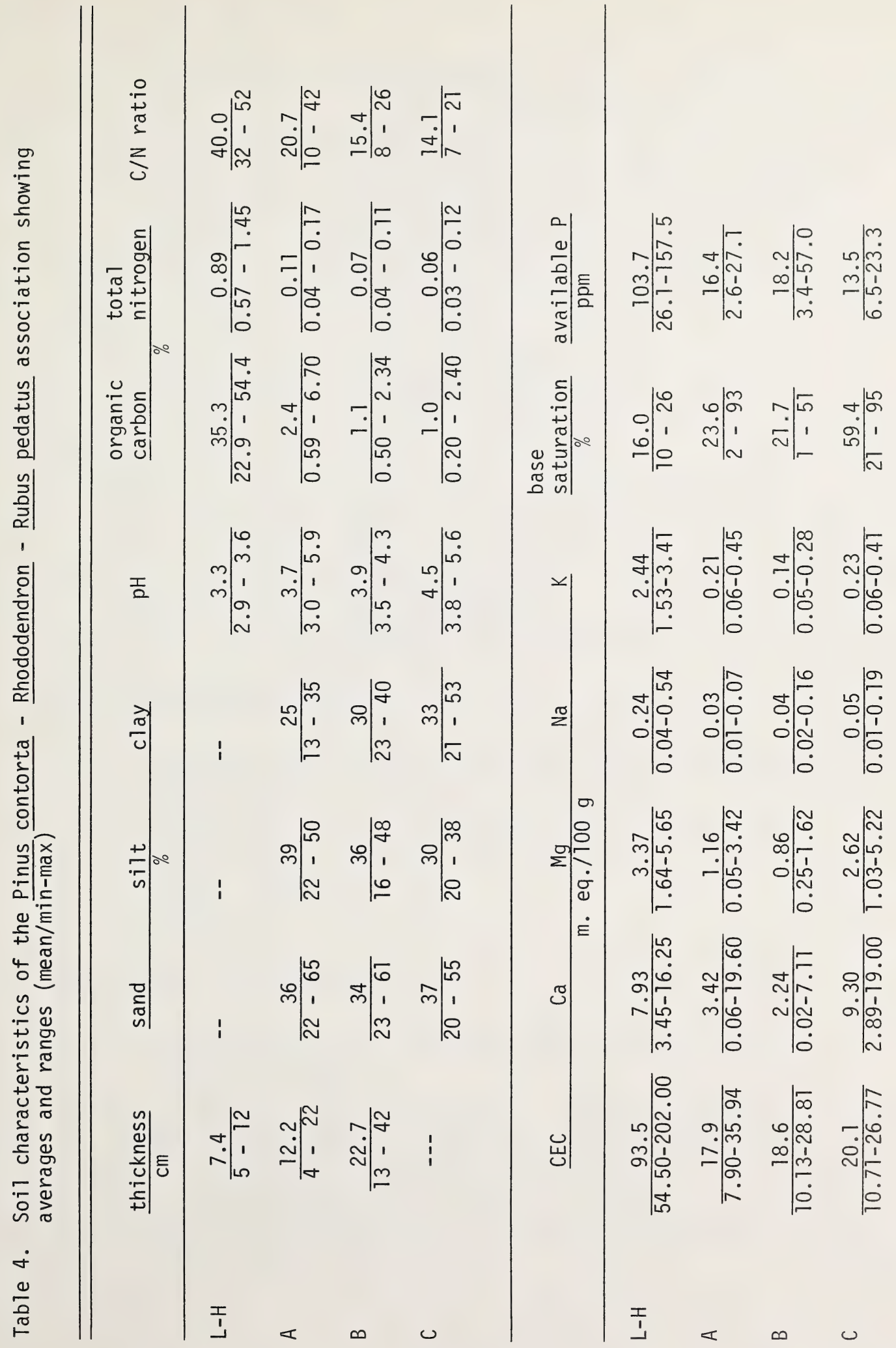





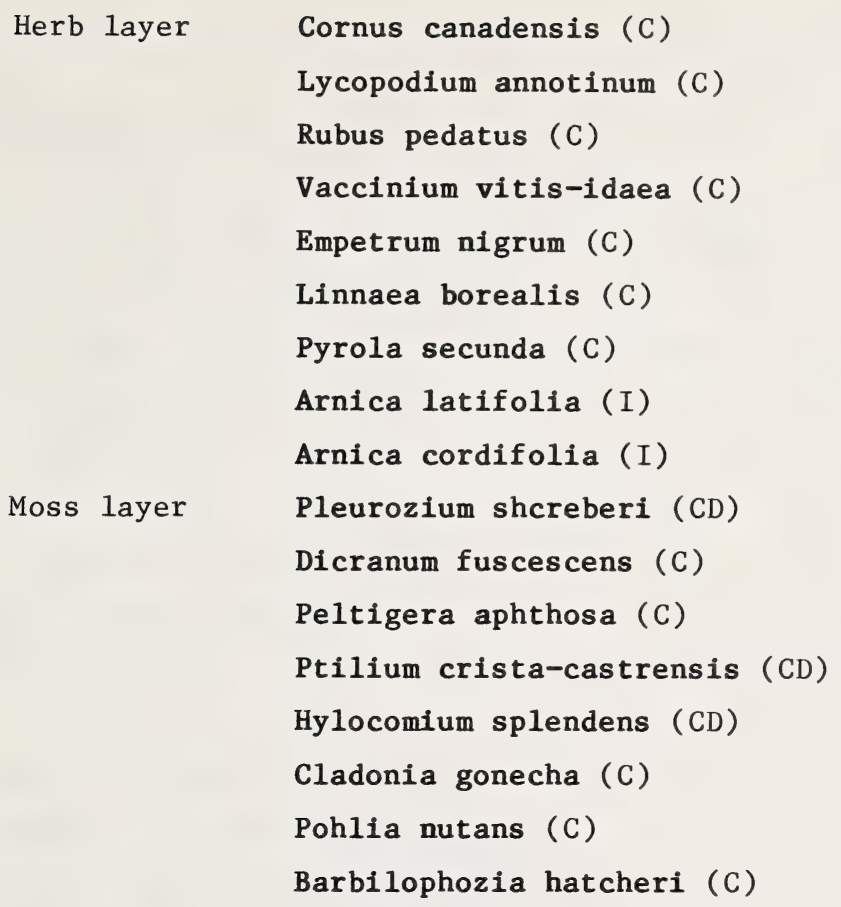

6.2.3.3 Site characteristics

- topographic position: upper to middle portions of gentle to steep slopes

- altitude range: from approximately 1,300 to $1,900 \mathrm{~m}$ as 1 .

- slope: level to $27^{\circ}$

- aspect: NW - N - NE - (E)

6.2.3.4 Soil characteristics

- soil classification: Degraded Dystric Brunisol, Orthic Dystric Brunisol

- soil moisture regime (hygrotope): submesic to mesic (3-4)

- soil nutrient regime (trophotope): oligotrophic to submesotrophic $(A-B)$

- depth to groundwater table: no water table detected to a depth of $100 \mathrm{~cm}$ 



\subsubsection{Successional stage: intermediate to early advanced}

\subsubsection{Forestry characteristics}

- total stem volume of standing trees, average and range:

$$
297.9(174.3-669.7) \mathrm{m}^{3} / \mathrm{ha}
$$

- percentage of total stem volume partitioned by species:

lodgepole pine - $63.9 \%$

subalpine fir - $15.7 \%$

black spruce - $10.2 \%$

Engelmann spruce - $10.2 \%$

- regeneration: moderate

- regeneration by: subalpine fir, black spruce and Engelmann spruce

- number of trees per hectare: 1,799

- average stand age: 122 years

- average height of dominant and co-dominant trees:

lodgepole pine, $14.3 \mathrm{~m}$;

subalpine fir and Engelmann spruce, $12.9 \mathrm{~m}$

- average height of forest canopy: $13.1 \mathrm{~m}$

- average mean annual increment: $2.18 \mathrm{~m}^{3} / \mathrm{ha}$

- site index: 1odgepole pine, $11.3 \mathrm{~m} / 70 \mathrm{yr}$;

black spruce, $10.5 \mathrm{~m} / 70 \mathrm{yr}$; subalpine fir, $8.0 \mathrm{~m} / 70 \mathrm{yr}$;

Engelmann spruce, $8.0 \mathrm{~m} / 70 \mathrm{yr}$

\subsubsection{Picea engelmannil/Abies lasiocarpa - Vaccinium membranaceum moss association}

\subsubsection{General description}

The moss association represents mesic to drier portions of subhygric ecosystems (Figure 22). It is the most common forested ecosystem throughout the study area, occurring on gentle slopes of various aspects and covering a wide range of landforms. Twenty-eight sample plots represent this association. 



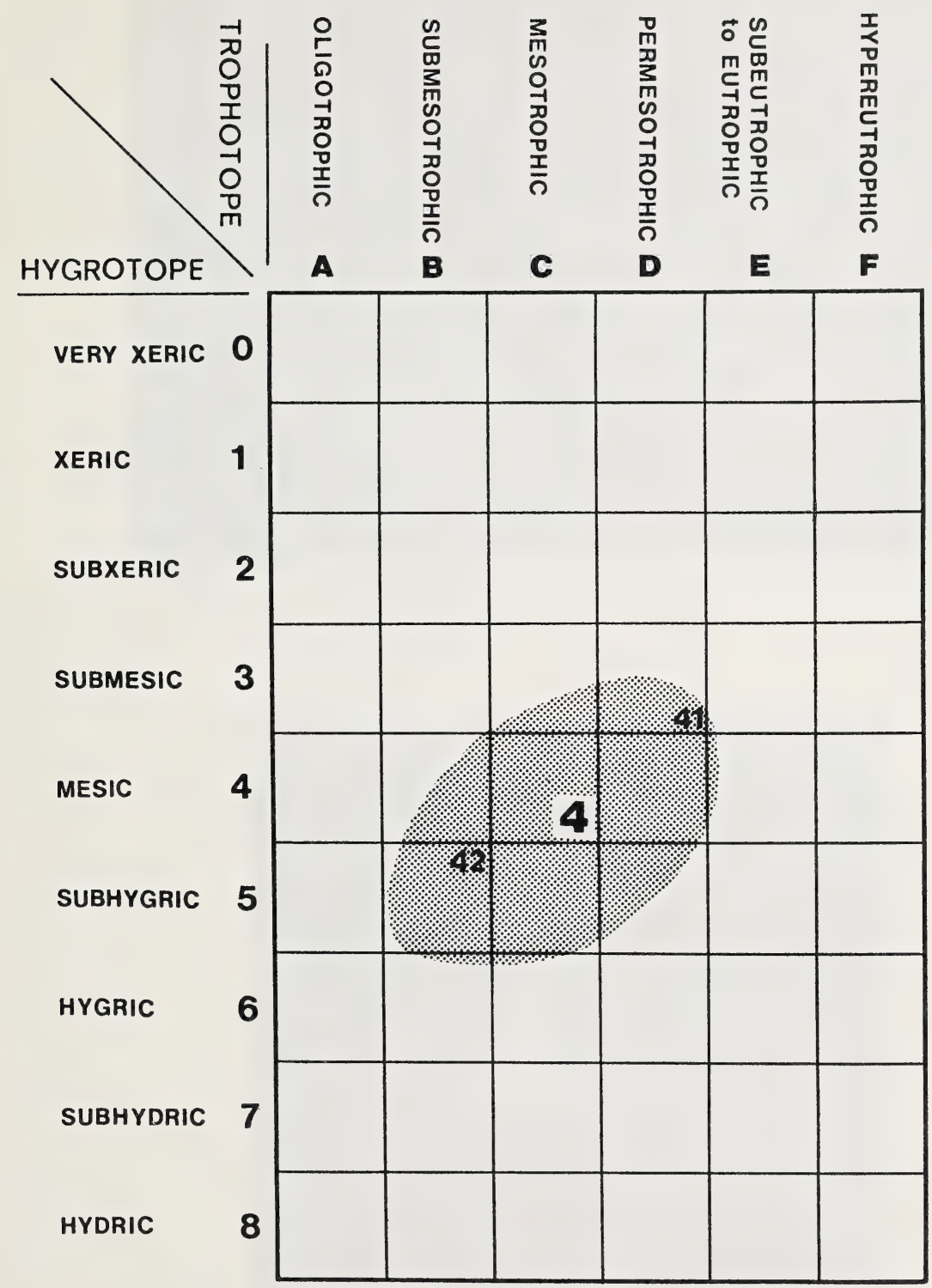

Figure 22. Edatopic position of the spruce/fir-moss association and its two subassociations (41: typical subassociation, 42: Ledum subassociation) 



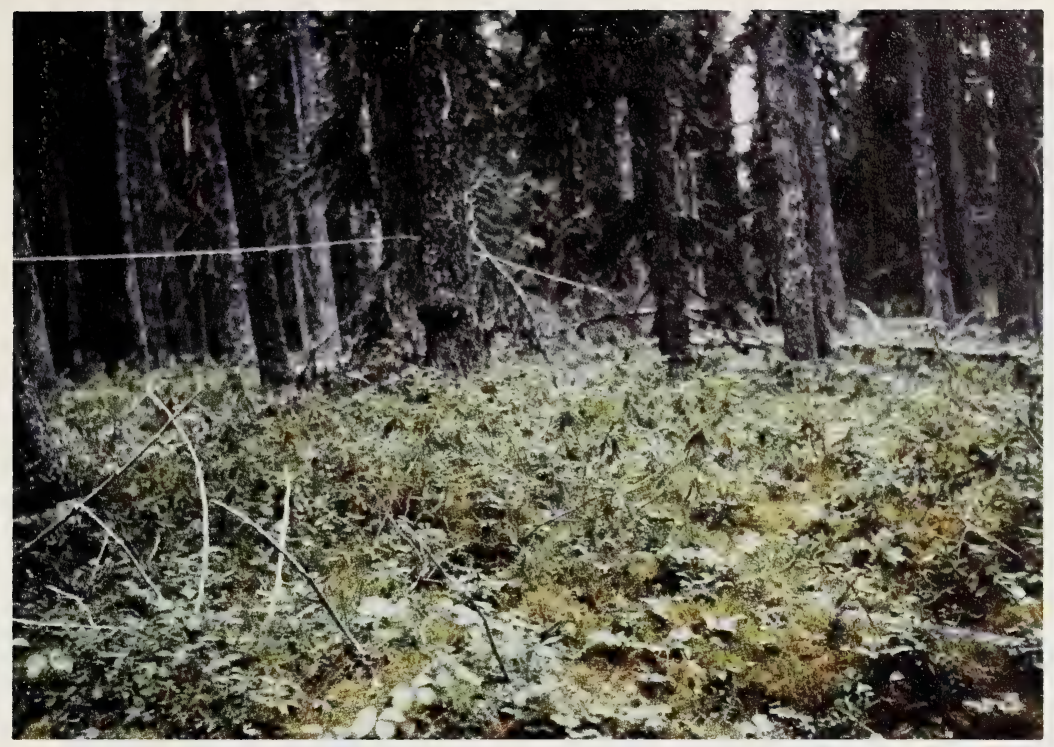

Figure 23. A forest stand of the Ledum subassociation of the spruce/fir-moss association

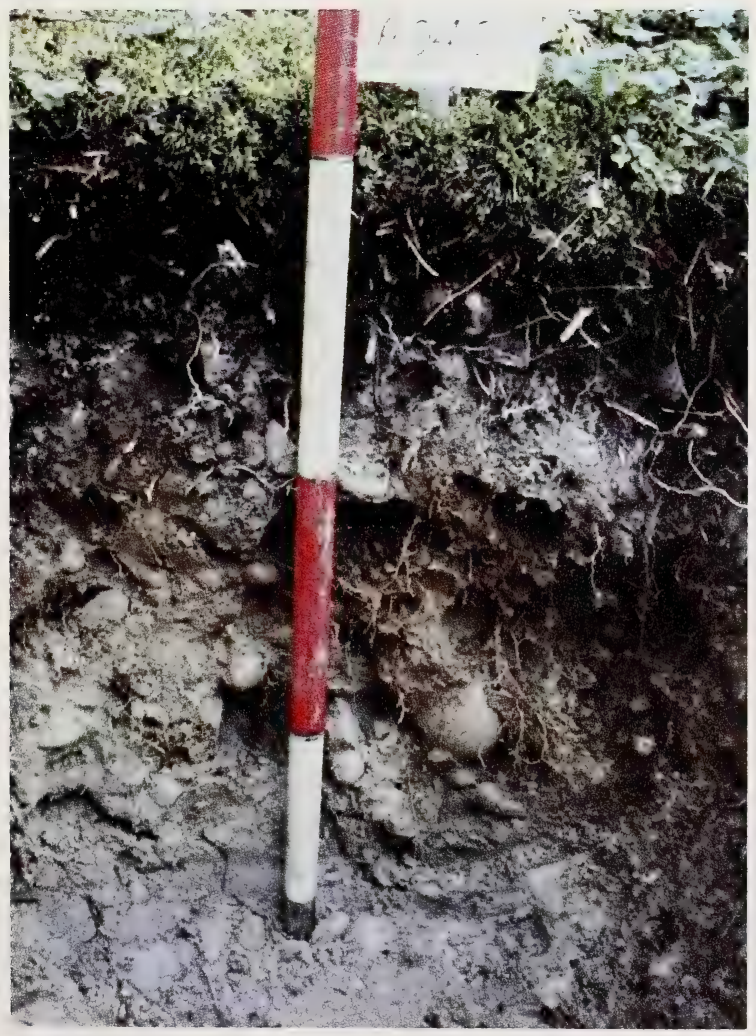

Figure 24. Soil profile of the Ledum subassociation of the spruce/fir-moss association 



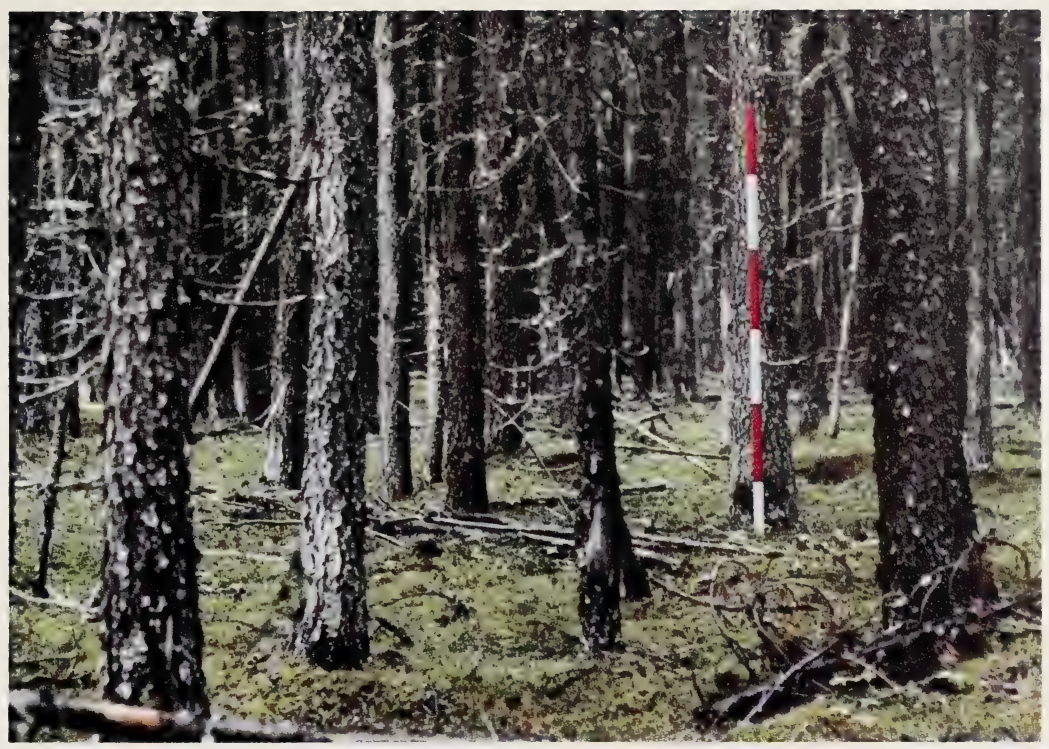

Figure 25. A forest stand of the typical subassociation of the spruce/fir-moss association

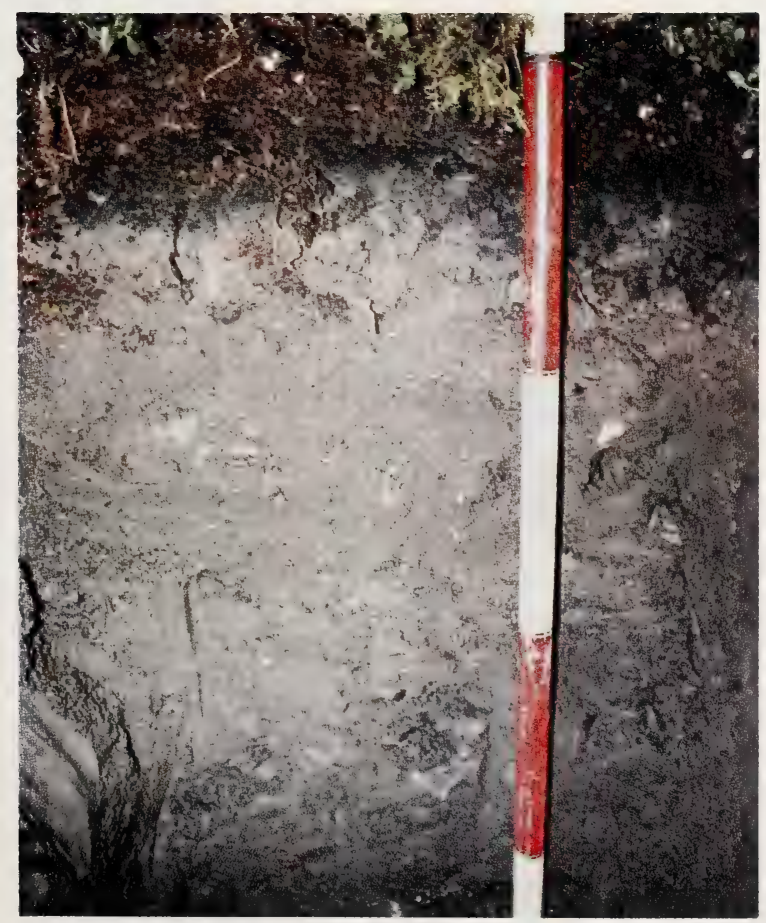

Figure 26. Soil profile of the typical subassociation of the spruce/fir-moss association 



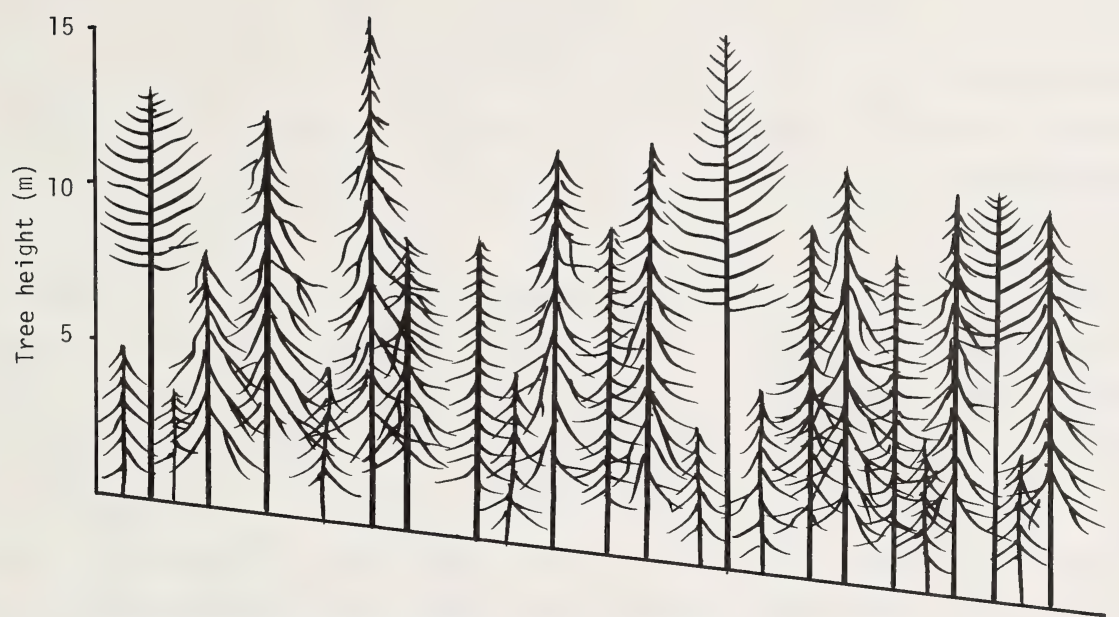

Profile sketch of the spruce/fir - moss association
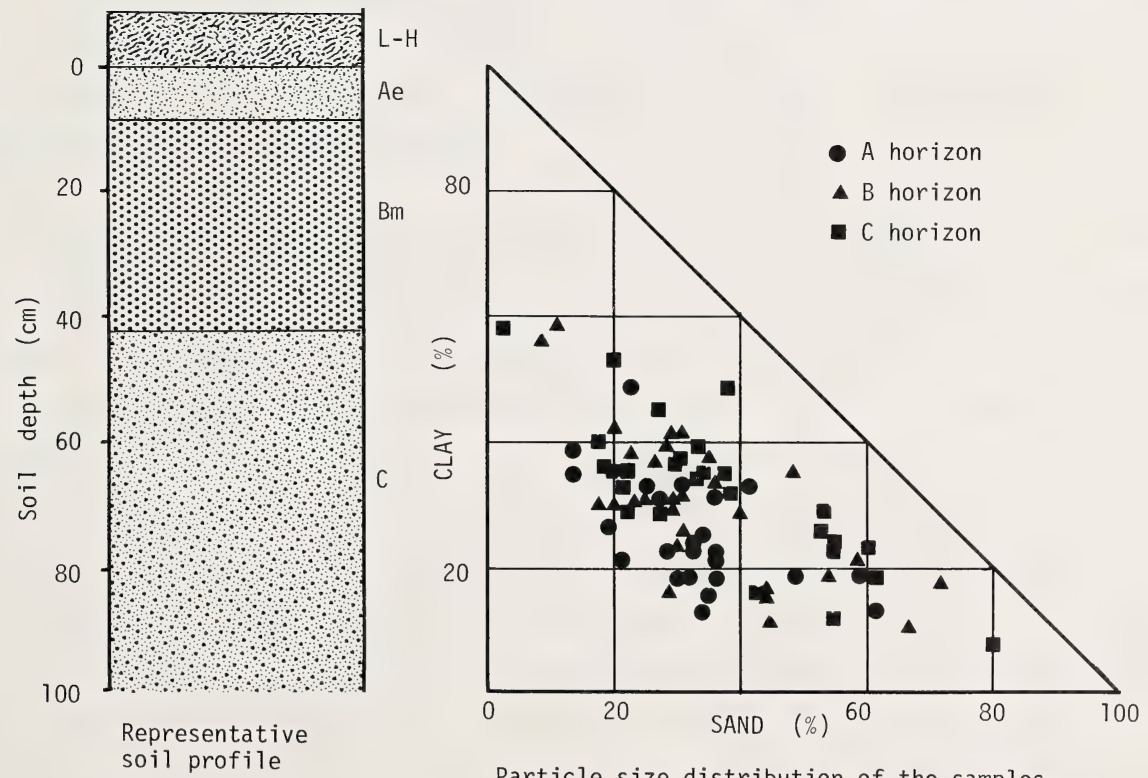

Particle size distribution of the samples representing different horizons distribution of the spruce/fir-moss association 

The tree layer is well developed with a mixture of Pinus contorta, Abies lasiocarpa, Picea engelmanni and Picea mariana (Figures 23 and 26). In the Swan Hills, there are hybrids between Abies lasiocarpa and Abies balsamea within this association. The presence of these tree species indicates an advanced successional stage. The shrub layer is moderately developed. Besides common occurrences of regenerating tree species, Vaccinium membranaceum shows a relatively high presence and dominance. Ledum groenlandicum and Vaccinium myrtilloides also commonly occur in the shrub layer. Development of the herb layer is weak with relatively low coverage of herbaceous plants. Nevertheless, Cornus canadensis and Rubus pedatus have a relatively high dominance. Other major species include Linnaea borealis, Vaccinium vitis-idaea, Pyrola secunda and Lycopodium annotinum. The moss layer is very well developed, forming a dense carpet over large areas (Figure 25). Major species of the moss layer include Hylocomium splendens, Pleurozium schreberi, Ptilium crista-castrensis, Dicranum fuscescens and Pohlia nutans. Lichens such as Peltigera aphthosa, Cladonia coniocraea and Cladonia gonecha are also common.

Soils are moderately fine to fine textured (Figure 26). The majority of samples are clay, clay loam, silty clay loam, and silty clay with some loam and sandy loam (Figure 27). Base status of the soils is rather low. Base saturation averages $37,26,49$ and $96 \%$ for the $\mathrm{L}-\mathrm{H}, \mathrm{A}, \mathrm{B}$ and $\mathrm{C}$ horizons, respectively. Recorded $\mathrm{pH}$ values are also low, presumably reflecting the low base status, with $\mathrm{pH}$ averaging $3.8,3.8,4.6$ and 5.2 for the $\mathrm{L}-\mathrm{H}, \mathrm{A}, \mathrm{B}$ and $\mathrm{C}$ horizons, respectively. The $\mathrm{C} / \mathrm{N}$ ratio is 37 for the $\mathrm{L}-\mathrm{H}$ horizon but decreases to 13 to 15 for the mineral horizons. Available phosphorus is relatively high in soils of this association (Table 5).

Forest productivity is medium with total volume of tree stems averaging $338.8 \mathrm{~m}^{3} / \mathrm{ha}$. Lodgepole pine is the major contributor to this volume. Other species such as subalpine fir (including hybrids with balsam fir), Engelmann spruce, black spruce and white spruce also contribute to a lesser extent. Average height of dominant and 



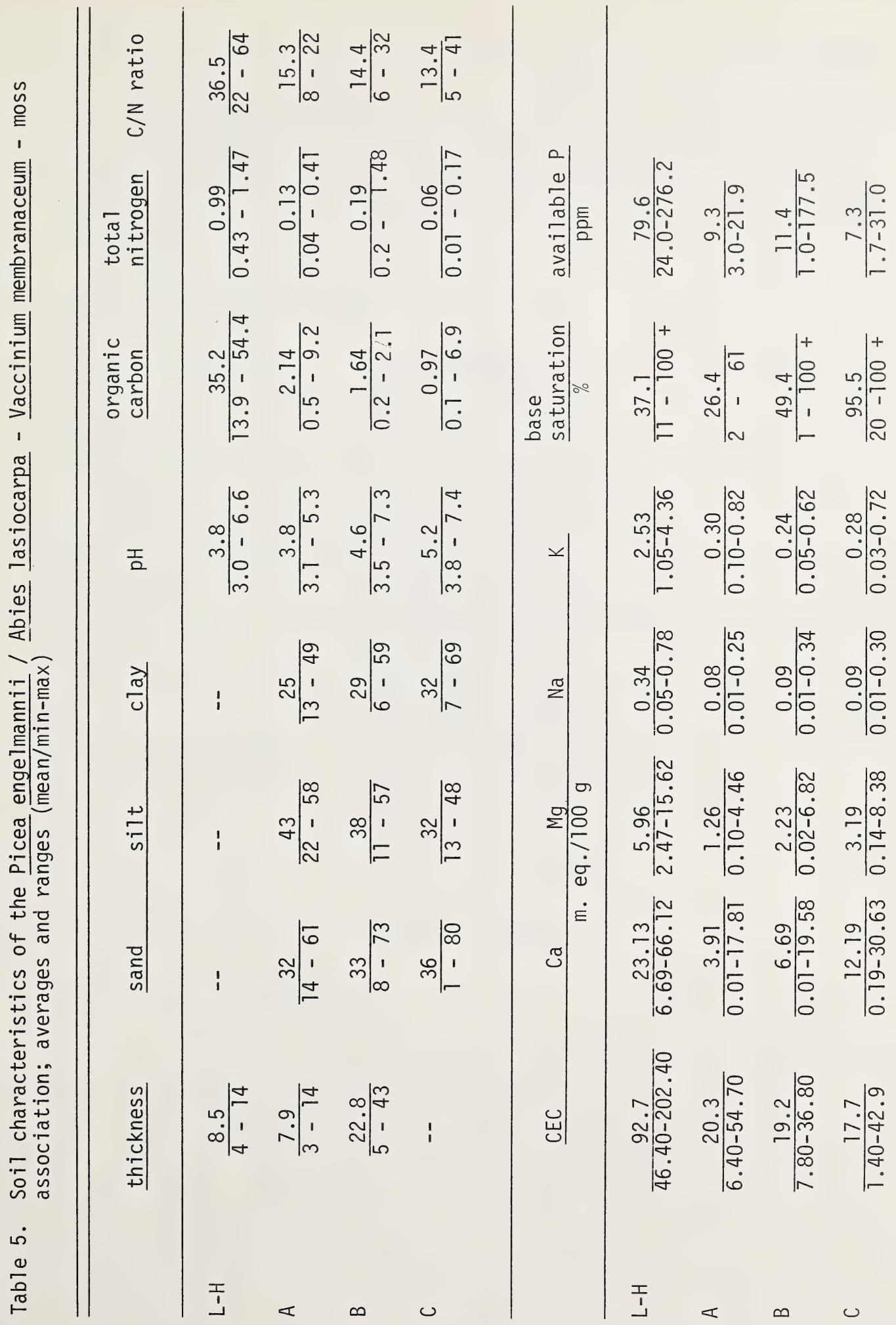



co-dominant trees is $16.9 \mathrm{~m}$ for lodgepole pine and $16.0 \mathrm{~m}$ for spruces and subalpine fir; average height of the forest canopy is $14.8 \mathrm{~m}$. Average mean annual increment is $2.43 \mathrm{~m}^{3} / \mathrm{ha}$. Site index of lodgepole pine is $13.0 \mathrm{~m} / 70$ years and for Engelmann spruce, black spruce, white spruce and subalpine fir is $9.1,10.6,10.0$ and $6.6 \mathrm{~m} / 70$ years, respectively.

6.2.4.2 Characteristic combination of species

$\begin{array}{ll}\text { Tree layer } & \text { Pinus contorta (CD) } \\ & \text { Abies lasiocarpa (CD) } \\ & \text { Picea engelmanni (I) } \\ \text { Shrub layer } & \text { Vaccinium membranaceum (CD) } \\ & \text { Ledum groenlandicum (CD) } \\ \text { Herb layer } & \text { Cornus canadensis (CD) } \\ & \text { Linnaea borealis (C) } \\ & \text { Vaccinium vitis-idaea (CD) } \\ & \text { Pyrola secunda (C) } \\ & \text { Rubus pedatus (CD) } \\ & \text { Lycopodium annotinum (C) } \\ & \text { Hylocomium splendens (CD) } \\ & \text { Pleurozium schreberi (CD) } \\ & \text { Ptilium crista-castrensis (CD) } \\ & \text { Dicranum fuscescens (C) } \\ \text { Moss layer } & \text { Pohlia nutans (C) } \\ & \text { Peltigera aphthosa (C) }\end{array}$

\subsubsection{Site characteristics}

- topographic position: middle to lower portions of mountain slopes and gently undulating hills

- altitude range: from approximately 1,100 to $1,800 \mathrm{~m}$ as 1

- slope: mostly level with some steep slopes up to $30^{\circ}$

- aspect: variable 



\subsubsection{Soil characteristics}

- soil classification: most of the soils are Eluviated Dystric

Brunisol or Orthic Dystric Brunisol, and rarely Orthic

Eutric Bruniso1, Eluviated Eutric Brunisol, Orthic Gray

Luvisol or Orthic Gleysol

- soil moisture regime (hygrotope): mesic to subhygric (4-5)

- soil nutrient regime (trophotope): submesotrophic to

permesotrophic (B-D)

- depth to groundwater table: generally no groundwater detected

to a depth of $100 \mathrm{~cm}$, but sometimes at 50 to $60 \mathrm{~cm}$ and rarely

as shallow as $25 \mathrm{~cm}$

\subsubsection{Successional stage: advanced}

\subsubsection{Forestry characteristics}

- total stem volume of standing trees, average and range:

$$
338.3(185.5-706.9) \mathrm{m}^{3} / \mathrm{ha}
$$

- percentage of total stem volume partitioned by species:

lodgepole pine (incl. hybrids with jack pine) - 40.5\%

subalpine fir (incl. hybrids with balsam fir) - $26.2 \%$

Engelmann spruce - $21.1 \%$

black spruce $-7.3 \%$

white spruce - $5.0 \%$

- regeneration: abundant

- regeneration by: Engelmann spruce, subalpine fir, black spruce

- number of trees per hectare: 1,852

- average stand age: 131 years

- average height of dominant and co-dominant trees:

lodgepole pine, $16.9 \mathrm{~m}$;

spruce and subalpine fir, $16.0 \mathrm{~m}$

- average height of forest canopy: $14.5 \mathrm{~m}$

- average mean annual increment: $2.43 \mathrm{~m}^{3} / \mathrm{ha}$

- site index: 1odgepole pine, $13.0 \mathrm{~m} / 70 \mathrm{yr}$;

black spruce, $10.6 \mathrm{~m} / 70 \mathrm{yr}$; white spruce, $10.6 \mathrm{~m} / 70 \mathrm{yr}$;

Engelmann spruce, $9.1 \mathrm{~m} / 70 \mathrm{yr}$; subalpine fir, $6.6 \mathrm{~m} / 70 \mathrm{yr}$ (10.0 for hybrids with balsam fir) 



\subsubsection{Subassociations of the moss association}

Because this association is very widespread in the study area, it includes a fairly wide range of habitats that range from comparatively dry to moist habitats and from fairly fertile to nutrient-poor habitats. Reflecting such edaphic differences, the vegetation also shows considerable variability within the association. Based on vegetation differences, this association may be divided into two subassociatons: 1) Ledum subassociation; and 2) typical subassociation.

The Ledum subassociation (Figure 23) is characterized by a comparatively we11 developed low shrub layer dominated by Vaccinium membranaceum and Ledum groenlandicum and some herbaceous species such as Vaccinium vitis-idaea, Rubus pedatus, Streptopus roseus and Equisetum sylvcaticum, all of which have better development in this subassociation than in the typical subassociation. The typical subassociation (Figure 25) is characterized by a relative lack of the above species and by a good development of Ribes lacustre, Rosa acicularis and Linnaea borealis.

Dominant species of the tree layer also differ slightly between the two subassociations. The Ledum subassociation is dominated by Pinus contorta, whereas the typical subassociation is dominated by Abies lasiocarpa. Some structural difference is also recognized in the moss layer as the former subassociation is dominated by Pleurozium schreberi, while the typical subassociation has Hylocomium splendens as a dominant. Vegetation differences between the two subassociations of the moss association are summarized in Table 6. 

TABLE 6. Vegetation differences between the two subassociations of the moss association

species

Pinus contorta

Vaccinium membranaceum

Ledum groenlandicum

Vaccinium vitis-idaea

Rubus pedatus

Streptopus roseus

Equisetum sylvaticum

Pleurozium schreberi

Abies lasiocarpa

Ribes lacustris

Rosa acicularie

Hylocomium splendens
Ledum

subassociation

\begin{tabular}{|c|}
\hline $\mathrm{V} / 7 *$ \\
$\mathrm{~V} / 6$ \\
$\mathrm{~V} / 6$ \\
$\mathrm{~V} / 5$ \\
$\mathrm{IV} / 2$ \\
$\mathrm{IV} /+$ \\
$\mathrm{IV} /+$ \\
$\mathrm{V} / 7$ \\
\hline $\mathrm{I} /+$ \\
- \\
$\mathrm{II} /+$ \\
$\mathrm{V} / 6$
\end{tabular}

Typical

subassociation

$\operatorname{III} / 4 *$

IV $/ 4$

III $/ 1$

$\mathrm{IV} / 3$

III $/+$

III/+

$\mathrm{II} /+$

$\mathrm{V} / 6$

IV $/ 6$

III $/+$

III $/+$

$\mathrm{V} / 8$

* The Roman numerals and numbers in these columns refer, respectively, to presence classes and to average species significance (rounded). 

Table 7. Comparison of soil characteristics in the two subassociations of the moss association

Horizons

Ledum

subassociation

L-H horizon:

$\mathrm{pH}$

Base saturation (\%)

3.3

23.3

Extractable calcium (m•eq./100 g) 12.99

Total nitrogen (\%)

$\mathrm{C} / \mathrm{N}$ ratio

Available phosphorus (ppm)

39.9

69.1
Typical

subassociation

A horizon:

$\mathrm{pH}$

$4 \cdot 3$

53.0

32.80

1.00

32.8

90.9

Base saturation (\%)

3.6

4.1

22.5

32.0

Extractable calcium (m•eq•/100 g)

4.91

7.88

Total nitrogen (\%)

0.11

0.17

$\mathrm{C} / \mathrm{N}$ ratio

14.2

16.0

Available phosphorus (ppm)

9.4

9.5

B horizon:

$\mathrm{pH}$

$4 \cdot 2$

4.8

Base saturation (\%)

34.1

63.8

Extractable calcium (m.eq./100 g)

4.91

7.88

Total nitrogen (\%)

0.07

0.12

$\mathrm{C} / \mathrm{N}$ ratio

14.0

15.4

Available phosphorus (ppm)

7.4

7.0

C horizon:

$\mathrm{pH}$

4.8

5.8

Base saturation (\%)

67.8

131.8

Extractable calcium (m.eq./100 g)

11.69

13.77

Total nitrogen (\%)

0.05

0.08

$\mathrm{C} / \mathrm{N}$ ratio

11.5

13.6

Available phosphorus (ppm)

8.9

6.3 

TABLE 8. Comparison of tree growth characteristics in the two subassociations of the moss association

\section{Ledum groenlandicum}

Factors

Total volume of tree stems $\left(\mathrm{m}^{3} / \mathrm{ha}\right)$

Number of trees/ha

Mean annual increment $\left(\mathrm{m}^{3} / \mathrm{ha}\right)$

Average height (m)

Average volume/tree $\left(\mathrm{m}^{3}\right)$

Site indices ( $\mathrm{m} / 70$ years)

lodgepole pine

Engelmann spruce

subalpine fir

black spruce subassociation

330.62

1,893

2.31

15.3

0.17

12.5

8.0

8.2

11.3
13.7

9.1

6.9

346.90

1,810

2.63

14.7

0.19

9.5 typical

subassociation 

Associated with the vegetation differences of the two subassociations of the moss association, there are considerable differences in soil characteristics, particularly, base status of the soils (Table 7). The Ledum subassociation is characterized by soils with a much lower base status than soils in the typical association. Base saturation in the Ledum subassociation is 22.3, 22.5, 34.1 and $67.8 \%$ for the $\mathrm{L}-\mathrm{H}, \mathrm{A}, \mathrm{B}$ and C horizons, respectively, whereas those in the typical subassociations are $53.0,32.0,63.8$ and $131.8 \%$, for the comparable horizons. The $\mathrm{pH}$ values are also considerably lower in the Ledum subassociation as they are 3.3, 3.6, 4.2 and 4.8 for the $\mathrm{L}-\mathrm{H}, \mathrm{A}, \mathrm{B}$ and $\mathrm{C}$ horizons, respectively, whereas they are $4.3,4.1,4.8$ and 5.8 for the comparable horizons in the typical subassociation. The amount of calcium is much higher in the typical subassociation than it is in the Ledum subassociation. Other soil parameters are not markedly different between the two subassociations, although available phosphorus and total nitrogen are slightly higher in the typical subassociation than in the Ledum subassociation.

In comparison with the Ledum subassociation, the typical subassociation provides a markedly better environment for tree growth from the soil nutrient point of view (Table 8). In general, the Ledum subassociation represents a comparatively poorer habitat of a submesotrophic ecosystem, whereas the typical subassociation represents a mesotrophic to permesotrophic ecosystem (Figure 22).

\subsubsection{Pinus contorta - Alnus crispa - Arnica cordifolia association}

\subsubsection{General description}

The alder association represents mesic to subhygric ecosystems with fertile soils (Figure 28). It occurs fairly commonly throughout the study area on gentle slopes of morainal landforms. This association occurs on a variety of aspects and tends to be confined to rather low elevations. Eight sample plots were obtained for this association. 



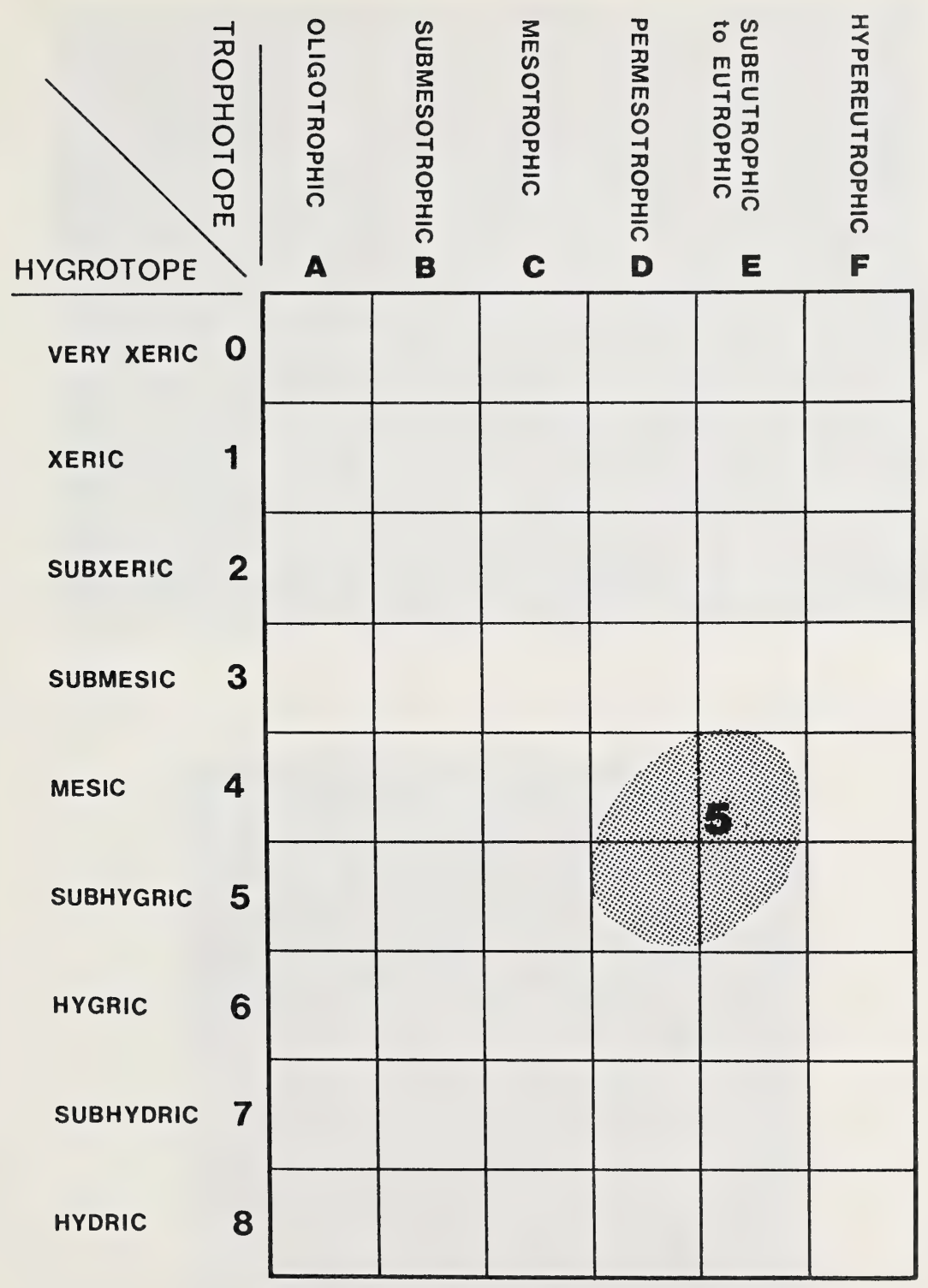

Figure 28. Edatopic position of the pine-alder association 



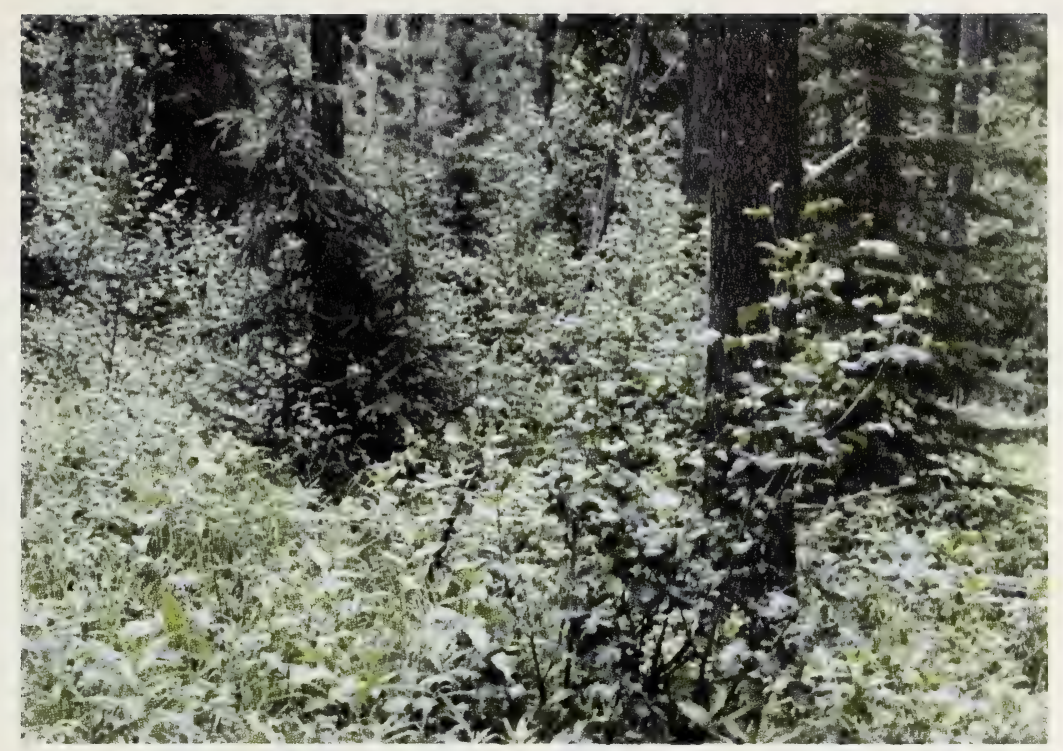

Figure 29. A forest stand of the pine-alder association

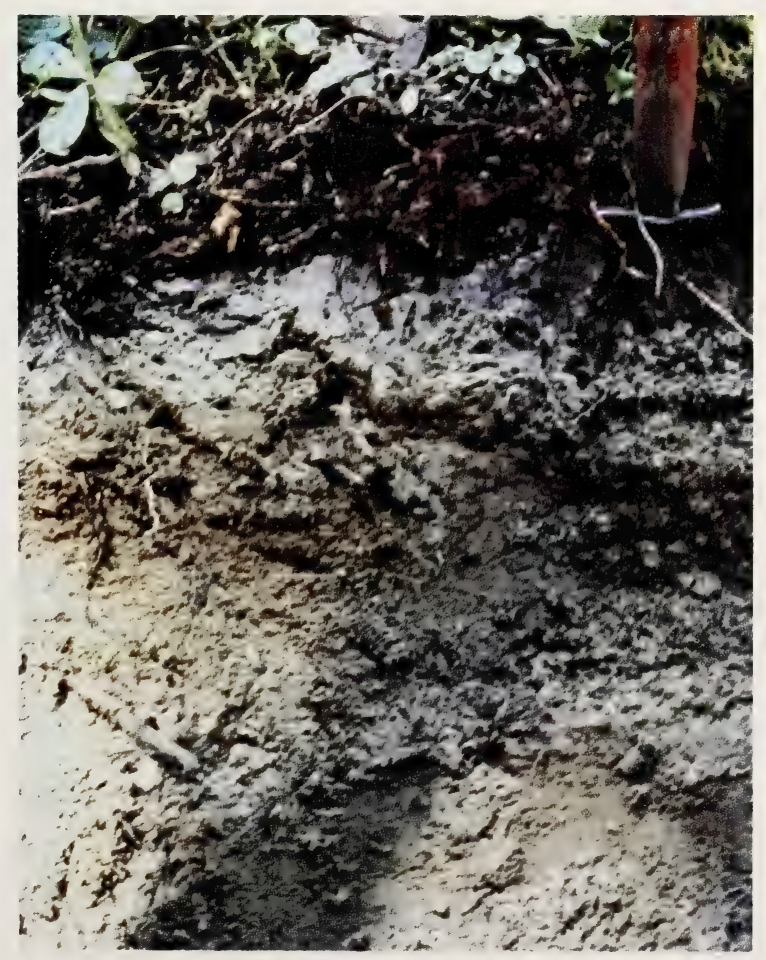

Figure 30 . Soil profile of the pine-alder association 


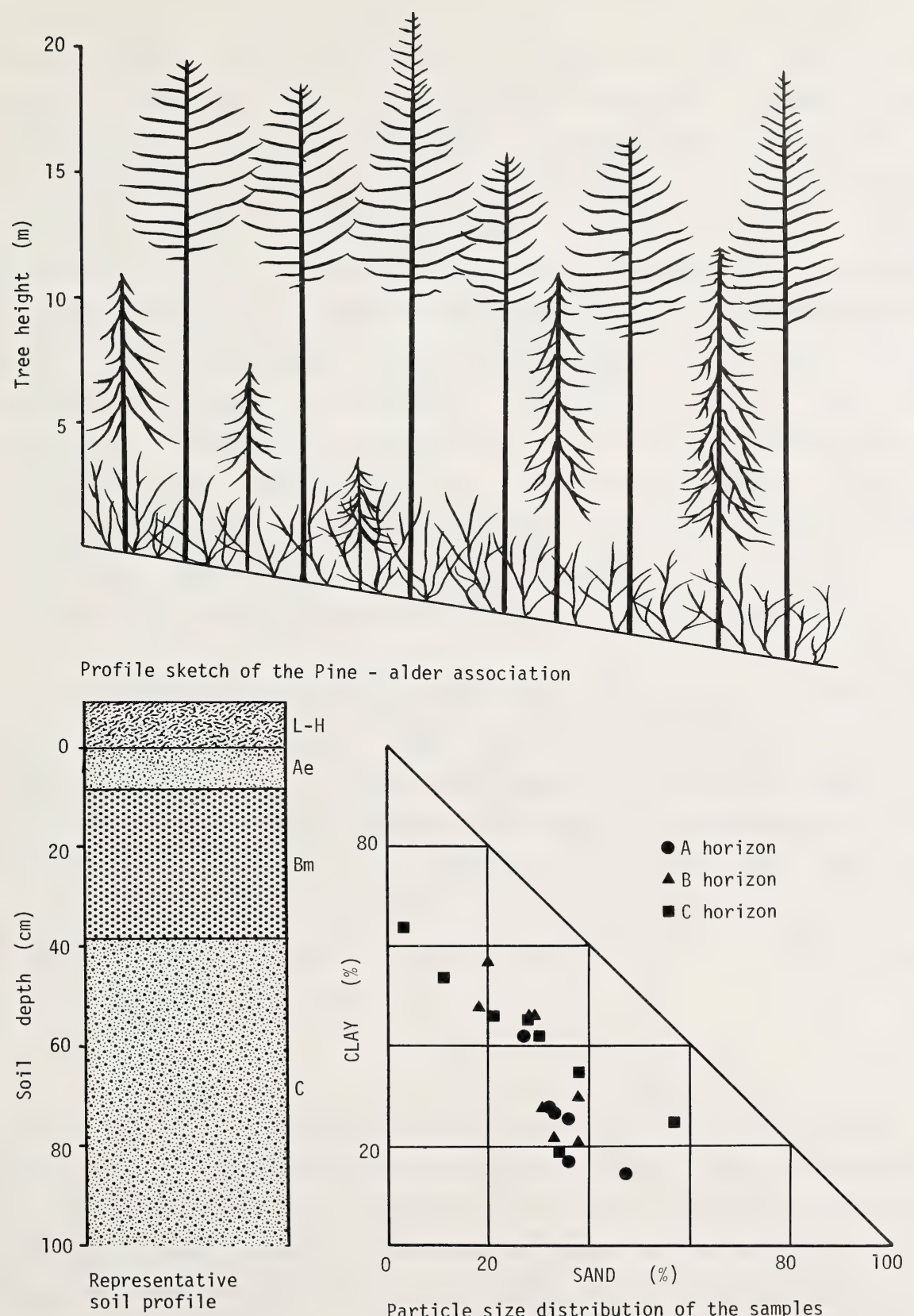

Particle size distribution of the samples representing different horizons

Figure 31 . Vegetation and soil profiles and soil particle size distribution of the pine-alder association 

The tree layer consists predominantly of even-aged Pinus contorta which shows excellent growth. Picea engelmannil (with some hybrids with Picea glauca) is common in the subordinate tree layer. The shrub layer is very well developed (Figure 29) and is overwhelmingly dominated by Alnus crispa, whose height may reach $5 \mathrm{~m}$. Other major species of the shrub layer include Rosa acicularis, viburnum edule and spiraea lucida. The herb layer is moderately developed and is dominated by cornus canadensis accompanied by Linnaea borealis, Epilobium angustifolium, Arnica cordifolia, Pyrola secunda, Calamagrostis canadensis, Rubus pubescens, Petasites palmatus and Pyrola asarifolia. Development of the moss layer is moderate. Pleurozium schreberi and Ptilium crista-castrensis co-dominate the moss layer, and other major species of the layer include Hylocomium splendens, Peltigera aphthosa, Cladonia gracilis, Dicranum fuscescens and Polytrichum juniperinum. The successional stage of this association was rated intermediate.

Soils are fine-textured (Figure 30), with most samples being clay, clay loam, and loam. Some samples were silty clay loam and sandy clay loam (Figure 31). Ground water may be present at a depth of 20 to $30 \mathrm{~cm}$ from the ground surface, although it is usually much deeper. Base status of soils in this association is rather high, with averages of $49,66,77$ and 96 for the L-H, A, B and C horizons, respectively. The $\mathrm{C} / \mathrm{N}$ ratio is moderate, ranging from 13 to 35 . Available phosphorus is also moderate (Table 9).

Forest productivity of the alder association is very high. It is the most productive association in all the study area. Total stem volume of standing trees averaged $414.1 \mathrm{~m}^{3} /$ ha. Lodgepole pine is the major contributor to this high volume, the Englemann spruce is second. Mean annual increment is $3.34 \mathrm{~m}^{3} / \mathrm{ha}$ which is also the highest rate of tree growth recorded in any of the forested plant associations in the study area. Average height of dominant and co-dominant lodgepole pine is $23.5 \mathrm{~m}$ on this association. Site index of lodgepole pine is $18.2 \mathrm{~m} / 70$ years, and for Engelmann spruce and subalpine fire 13.0 and $18.0 \mathrm{~m} / 70$ years, respectively. 



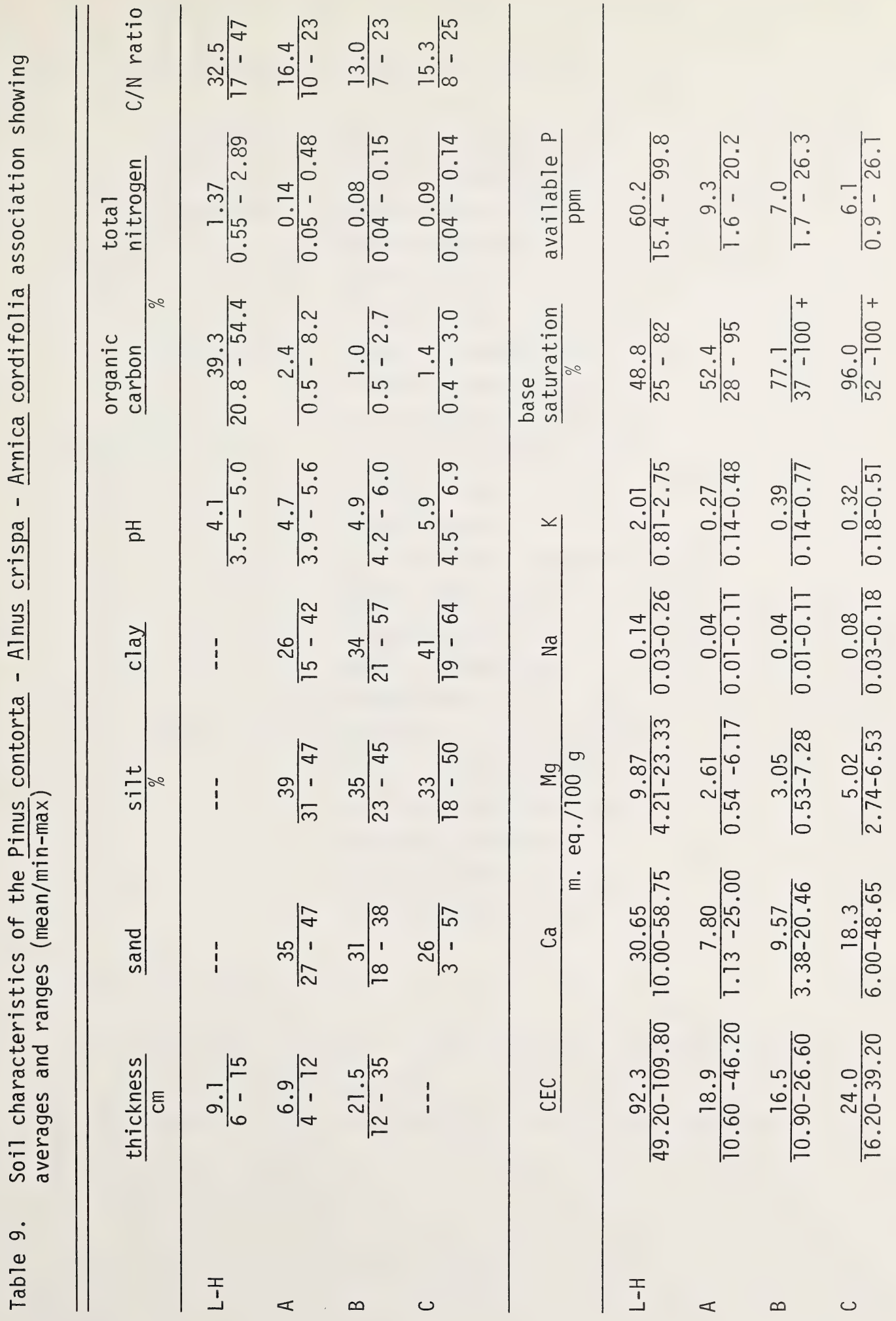



6.2.5.2 Characteristic combination of species

\begin{tabular}{|c|c|}
\hline Tree layer & $\begin{array}{l}\text { Pinus contorta (CD) } \\
\text { Picea engelmannii (I) }\end{array}$ \\
\hline Shrub layer & $\begin{array}{l}\text { Alnus crispa (CD) } \\
\text { Rosa acicularis (C) } \\
\text { Spiraea lucida (C) } \\
\text { Viburnum edule (C) }\end{array}$ \\
\hline Herb layer & $\begin{array}{l}\text { Linnaea borealis (C) } \\
\text { Cornus canadensis (CD) } \\
\text { Vaccinium vitis-idaea (C) } \\
\text { Epilobium angustifolium (C) } \\
\text { Arnica cordifolia (C) } \\
\text { Pyrola secunda (C) } \\
\text { Calamagrostis canadensis (C) } \\
\text { Rubus pubescens (C) } \\
\text { Petasites palmatus (C) } \\
\text { Pyrola asarifolia (I) } \\
\text { Rubus pedatus (I) }\end{array}$ \\
\hline Moss layer & $\begin{array}{l}\text { Pleurozium schreberi (CD) } \\
\text { Ptilium crista-castrensis (CD) } \\
\text { Hylocomium splendens (CD) } \\
\text { Peltigera aphthosa (C) } \\
\text { Dicranum fuscescens (C) } \\
\text { Dicranum scoparium (C) }\end{array}$ \\
\hline
\end{tabular}

\subsubsection{Site characteristics}

- topographic position: middle slopes or level topography on gently undulating hills

- altitude range: from approximately 1,000 to $1,600 \mathrm{~m}$ as 1

- slope: gentle

- aspect: variable 



\subsubsection{Soil characteristics}

- soil classification: mostly Orthic Dystric Brunisol, rarely Orthic Gray Luvisol

- soil moisture regime (hygrotope): mesic to subhygric (4-5)

- soil nutrient regime (trophotope): permesotrophic to subeutrophic (D-E)

- Depth to groundwater table: in some soils, no groundwater detected to a depth of $100 \mathrm{~cm}$, but often at $90 \mathrm{~cm}$ and sometimes as shallow as $20 \mathrm{~cm}$

\subsubsection{Successional stage: intermediate}

\subsubsection{Forestry characteristics}

- total stem volume of standing trees, average and range:

$$
414.1\left(128.9 \text { - 513.6) } \mathrm{m}^{3} / \mathrm{ha}\right.
$$

- percentage of total stem volume partitioned by species:

$$
\begin{array}{ll}
\text { lodgepole pine }-72.5 \% & \text { subalpine fir }-0.8 \% \\
\text { Engelmann spruce }-20.4 \% & \text { black spruce }-0.8 \% \\
\text { balsam poplar }-4.8 \% & \text { aspen }-0.7 \%
\end{array}
$$

- regeneration: moderate

- regeneration by: Engelmann spruce

- number of trees per hectare: 742

- average stand age: 122 years

- average height of dominant and co-dominant trees:

lodgepole pine, $23.5 \mathrm{~m}$

- average height of forest canopy: $20.8 \mathrm{~m}$

- mean annual increment: $3.34 \mathrm{~m}^{3} / \mathrm{ha}$

- site index: lodgepole pine, $18.2 \mathrm{~m} / 70 \mathrm{yr}$;

subalpine. fir, $18.0 \mathrm{~m} / 70 \mathrm{yr}$; Engelmann spruce*, $13.0 \mathrm{~m} / 70 \mathrm{yr}$ 



\subsubsection{Picea mariana - Salix spp. - Equisetum spp. association}

6.2.6.1 General description

The Equisetum association represents hygric ecosystems (Figure 32). It develops on lower slopes, in valley bottoms and depressions, or in areas of undulating topography where water collects. Twelve sample plots were obtained for this association.

The tree layer is well developed, and is dominated by Picea mariana. Some Picea glauca is present and it is hybridized with Picea engelmannil. Abies lasiocarpa occurs occasionally and at lower elevations there are rare occurrences of Larix laricina. The well developed shrub layer is dominated by Salix species, mainly $\mathrm{S}$. barclayi, S. farrae, S. myrtillifolia, S. planifolia and S. barrattiana. Lonicera involucrata, Ledum groenlandicum and Rosa acicularis are common. Other major shrub species include Betula glandulosa, Ribes triste, Ribes lacustre and Ribes hudsonianum. The herb layer is luxuriously developed, and is overwhelmingly dominated by Equisetum species, mainly E. arvense, E. pratense and E. sylvaticum (Figure 33). Other major constituents of the herb layer are Mitella nuda, Mertensia paniculata, Petasites palmatus, Vaccinium vitis-idaea, Carex vaginata, Calamagrostis canadensis, Equisetum scirpoides, Cornus canadensis, Carex disperma, Rubus acaulis and Senecio triangularis. The herb layer of this association is characteristically rich in vascular flora with a total of 77 species recorded in the layer, which is the highest number of herbaceous species of the eight associations described in this study. The moss layer is moderately developed, and is dominated by Hylocomium splendens, followed by Peltigera aphthosa and Ptilium crista-castrensis. Reflecting the hygric habitats, such species as Sphagnum warnstorffii, Aulacomnium palustre and Tomenthypnum nitens frequently occur.

Soils are fine to moderately fine-textured (Figure 34). Most samples were clay, silty clay, sandy loam, clay loam, with some loam and sandy loam (Figure 35). Base status of this association is 



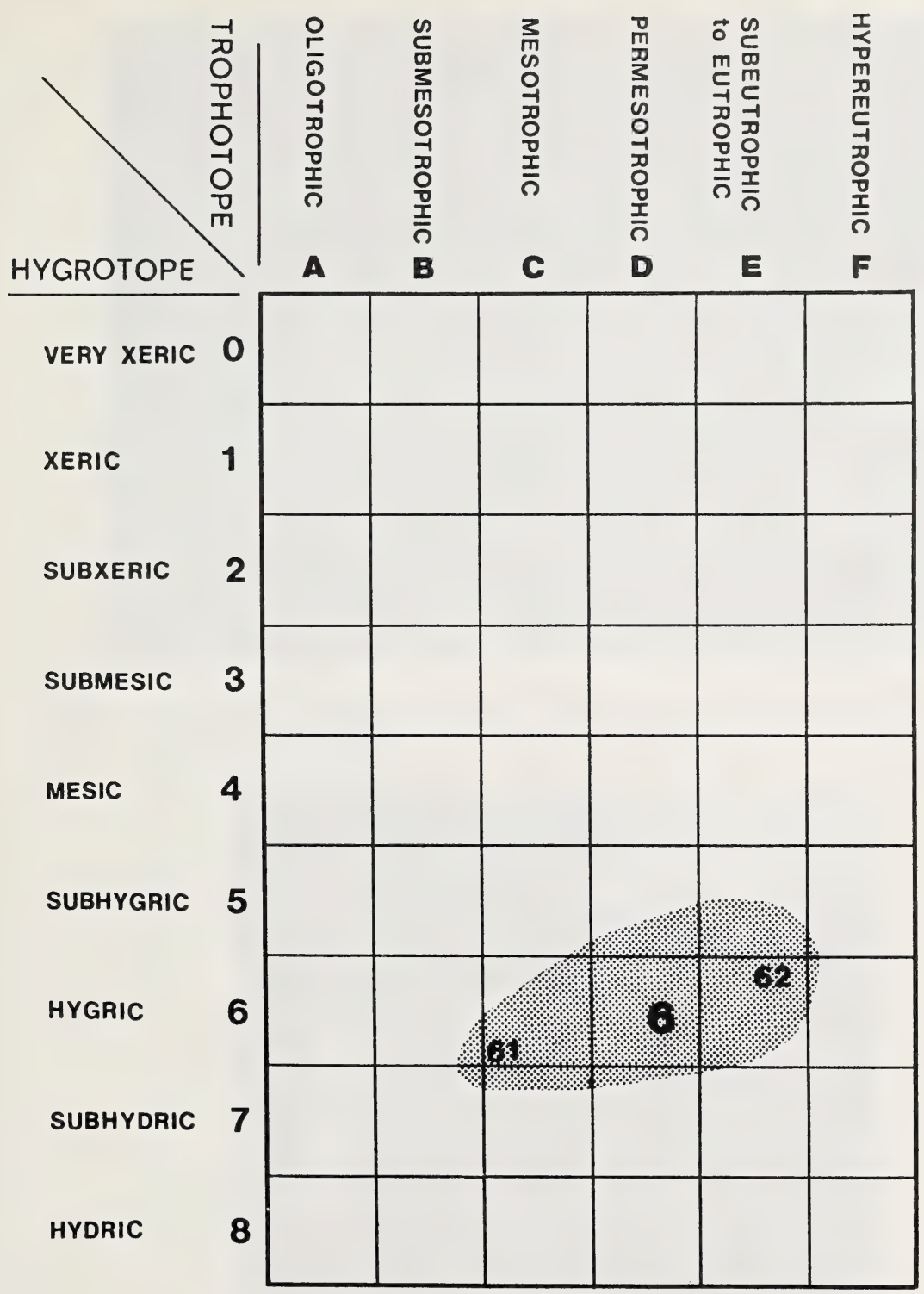

Figure 32. Edatopic position of the spruce-willow-Equisetum association and its two subassociations (61: Equisetum sylvaticum subassociation, 62: Equisetum pratense subassociation) 



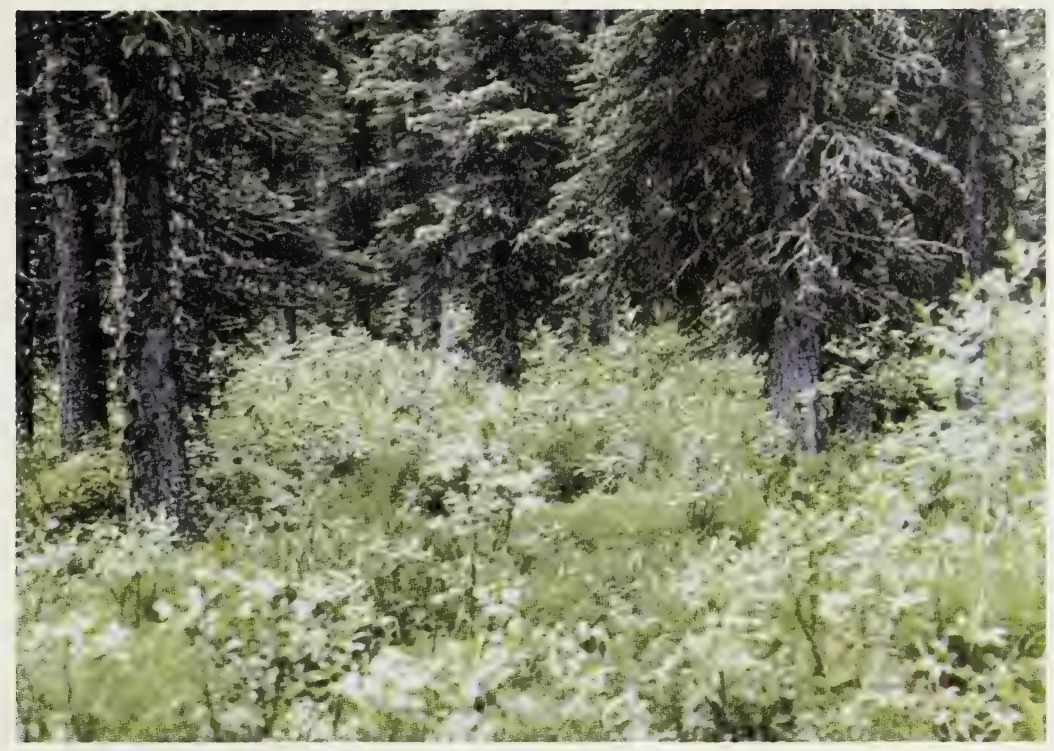

Figure 33. A forest stand of the spruce-willow-Equisetum association

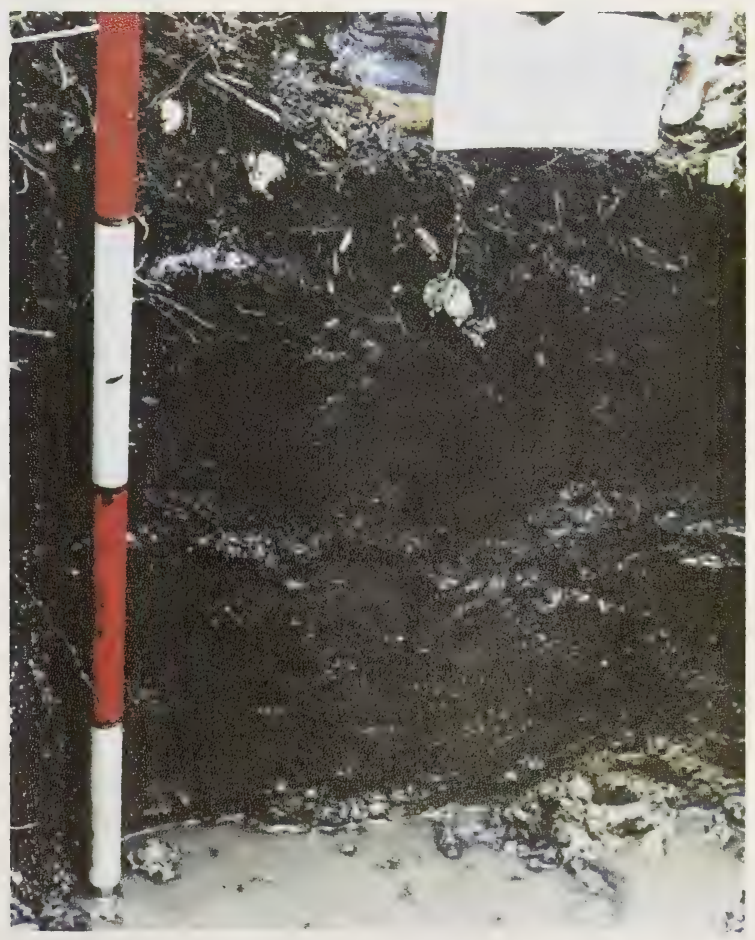

Figure 34. Soil profile of the spruce-willow-Equisetum association 



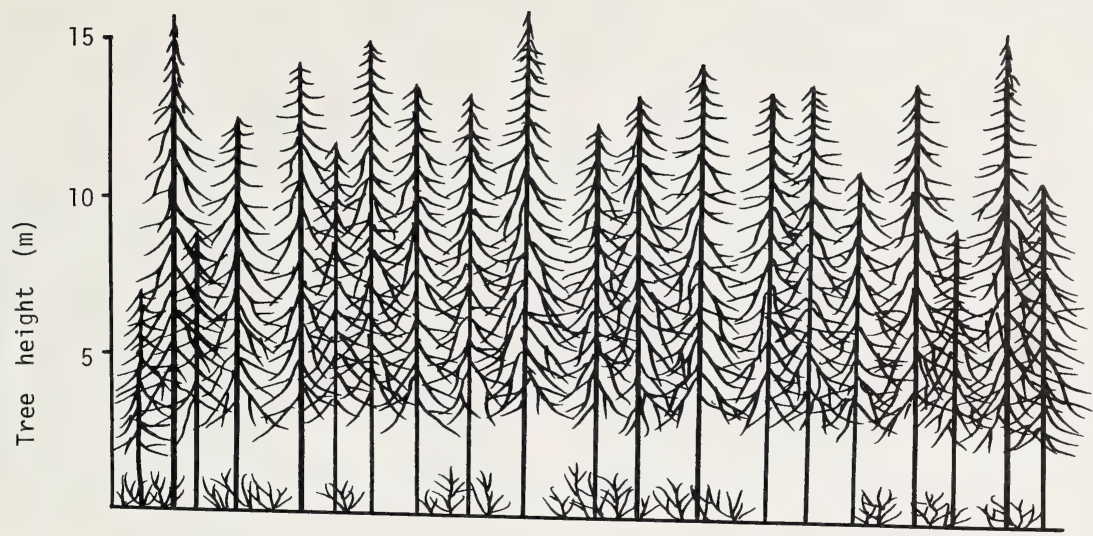

Profile sketch of the Spruce - willow - Equisetum association
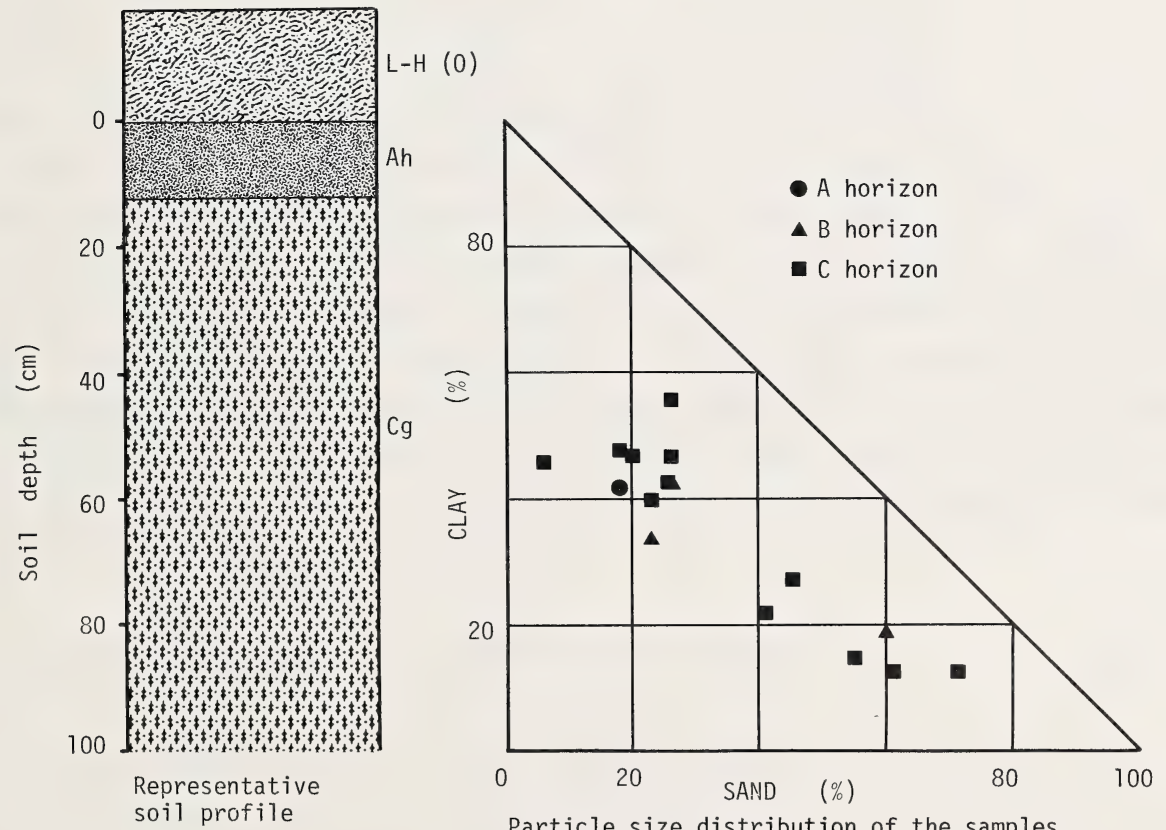

Particle size distribution of the samples representing different horizons

Figure 35. Vegetation and soil profiles and soil particle size distribution of the spruce-willow-Equisetum association 

generally fairly high, presumably reflecting the influx of basic cations with seepage water. Averages of base saturation are 80, 77, 108 and $106 \%$ for the L-H, A, B and C horizons, respectively. Averages of $\mathrm{pH}$ are also high as they are 5.6, 5.4, 6.1 and 6.0 for the L-H, A, B and $\mathrm{C}$ horizons, respectively. The average $\mathrm{C} / \mathrm{N}$ ratio is 30 for the organic horizon and ranges from 17 to 24 for the mineral horizons (Table 10). The water table is high in this association and was recorded at an average depth of $18 \mathrm{~cm}$ below the ground surface. Most of the soils, therefore, show gleyed effects due to poor aeration in the mineral horizon. Soils of this association have a distinctive accumulation of organic matter in the form of peat.

Forest productivity is low in the Equisetum association. The average total volume of tree stems is $274.8 \mathrm{~m}^{3} / \mathrm{ha}$, which is the second lowest of the six associations in the lower subzone. Black spruce is the major contributor of the volume followed by white spruce and Engelmann spruce. Average height of dominant and co-dominant spruce is $15.7 \mathrm{~m}$ and average height of the forest canopy is $13.8 \mathrm{~m}$. Average mean annual increment is $1.65 \mathrm{~m}^{3} / \mathrm{ha}$, which is the lowest of the six associations of the lower subzone. Site index of black spruce is $9.4 \mathrm{~m} / 70$ years; those of white spruce and Engelmann spruce are 9.4 and $8.0 \mathrm{~m} / 70$ years, respectively. The low productivity of this association, despite the high base status of its soils, may be attributed to poor soil aeration, as most soils are permanently water-saturated. Trees, especially black spruce, are small and densely stocked in this association.

\subsubsection{Characteristic combination of species}

$\begin{array}{ll}\text { Tree layer } & \text { Picea mariana (CD) } \\ & \text { Picea glauca (I) } \\ & \text { Picea engelmannii (I) } \\ \text { Shrub layer } & \text { Salix barclayi (CD) } \\ & \text { Lonicera involucrata (C) } \\ & \text { Ledum groenlandicum (C) } \\ & \text { Rosa acicularis (C) } \\ & \text { Ribes triste (I) } \\ & \text { Ribes lacustre (I) } \\ & \text { Betula glandulosa (I) } \\ & \text { Ribes hudsonianum (I) }\end{array}$





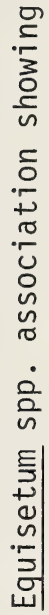

1
$\frac{0}{2}$
in
ñ

$\frac{\frac{\pi}{\sigma}}{\frac{\pi}{\sigma}}$

送

을

实

تॄ

政

पु

要

政

금

$\stackrel{\circ}{\circ}$

$\frac{0}{\frac{0}{6}}$

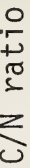

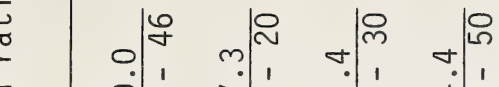

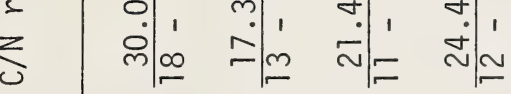

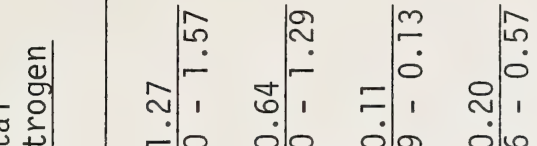

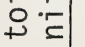

- ০

\begin{tabular}{l|l|l|l}
0 & 0 & 0 & 0 \\
0 & 0 & 0
\end{tabular}

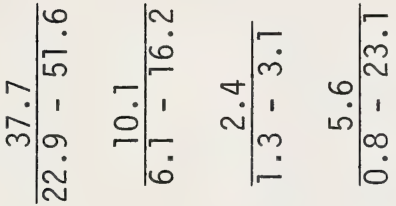

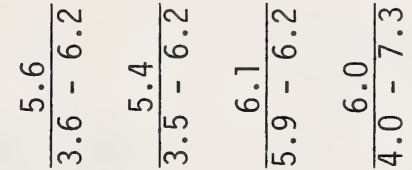

ฮै

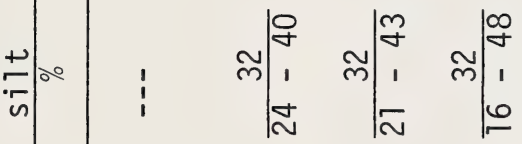

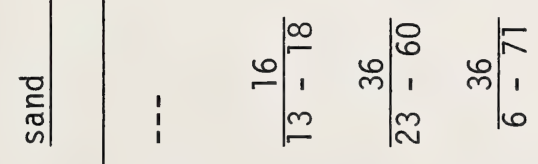

$\tilde{\omega}$

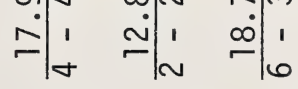

$\underset{1}{ \pm}$

$\leftarrow$

$\infty$

$\checkmark$

$\stackrel{乛}{2}$

요

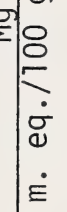

岃|

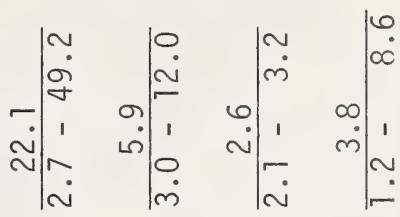

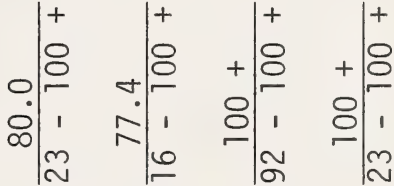

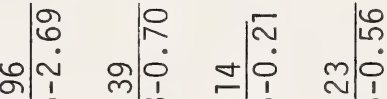

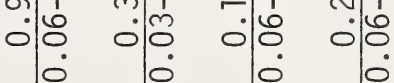

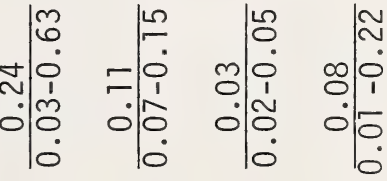

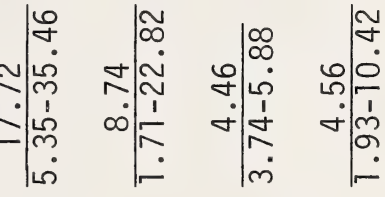

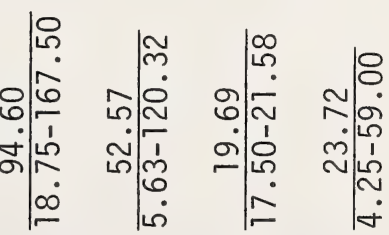

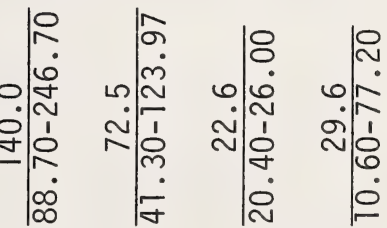





$\begin{array}{ll}\text { Herb layer } & \text { Equisetum arvense (CD) } \\ \text { Equisetum sylvaticum(CD) } \\ \text { Equisetum pratense (CD) } \\ \text { Mitella nuda (C) } \\ \text { Mertensia paniculata (C) } \\ \text { Petasites palmatus (C) } \\ \text { Vaccinium vitis-idaea (C) } \\ \text { Carex vaginata (C) } \\ \text { Calamagrostis canadensis (C) } \\ \text { Cornus canadensis (C) } \\ \text { Carex disperma (C) } \\ \text { Rubus acaulis (C) } \\ \text { Senecio triangularis (C) } \\ \text { Geum rivale (I) } \\ \text { Delphinium glaucum (I) } \\ \text { Anemone richardsonii (I) } \\ \text { Hylocomium splendens (CD) } \\ \text { Peltigera aphthosa (C) } \\ \text { Ptilium crista-castrensis (CD) } \\ \text { Pleurozium schreberi (CD) } \\ \text { Aulacomnium palustre (CD) } \\ \text { Pohlia nutans (C) } \\ \text { Tomenthypnum nitens (I) } \\ \text { Sphagnum fuscum (I) } \\ \text { Sphagnum warnstorfii (I) } \\ \text { Moss layer }\end{array}$

\subsubsection{Site characteristics}

- topographic position: lower slopes, and in depressions amongst undulating hills and plateaus

- altitude range: from approximately 1,000 to $1,700 \mathrm{~m}$ as 1

- slope: mostly level, some slopes to $9^{\circ}$

- aspect: variable 



\subsubsection{Soil characteristics}

- soil classification: Orthic Gleysol, Rego Gleysol, Rego Humic Gleysol and Organic soils (Terric Mesisol and Typic Mesisol)

- soil moisture regime (hygrotope): hygric to subhydric (6-7)

- soil nutrient regime (trophotope): mesotrophic to

subeutrophic (C-E)

- depth to groundwater table: generally 20 to $30 \mathrm{~cm}$, but some sites with water up to the surface and some with no groundwater detected to a depth of $100 \mathrm{~cm}$.

\subsubsection{Successional stage: advanced}

\subsubsection{Forestry characteristics}

- total stem volume of standing trees, average and range:

$$
274.8(76.6-720.0) \mathrm{m}^{3} / \mathrm{ha}
$$

- percentage of total stem volume partitioned by species:

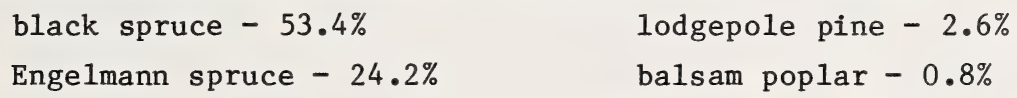

- regeneration: moderate

- regeneration by: black spruce, white spruce, Engelmann spruce

- number of trees per hectare: 1,835

- average stand age: 154 years

- average height of dominant and co-dominant trees:

spruce, $15.7 \mathrm{~m}$

- average height of forest canopy: $13.8 \mathrm{~m}$

- average mean annual increment: $1.65 \mathrm{~m}^{3} / \mathrm{ha}$

- site index: lodgepole pine, $10.3 \mathrm{~m} / 70 \mathrm{yr}$;

black spruce, $9.4 \mathrm{~m} / 70 \mathrm{yr}$; Engelmann spruce*, $8.0 \mathrm{~m} / 70 \mathrm{yr}$

\subsubsection{Subassociations of the Equisetum association}

Based on vegetation differences, the Equisetum association can be divided into two subassociation: 1) Equisetum sylvaticum subassociation; and 2) Equisetum pratense subassociation (Table 11).

* including some hybrids with Picea glauca. 

The Equisetum sylvaticum subassociation is differentiated from the other subassociation by a higher coverage of Picea mariana, Ledum groenlandicum, Salix barclayi, Equisetum sylvaticum, Vaccinium vitis-idaea, Petasites palmatus, Calamagrostis canadensis, Cornus canadensis, Carex vaginata, Deschampsia caespitosa, Carex disperma, Rubus chamaemorus, Aster ciliolatus, Geum rivale, Linnaea borealis, Listera cordata, Pleurozium schreberi, Ptilium crista-castrensis and Tomenthypnum nitens. The Equisetum pratense subassociation, on the other hand, is differentiated by comparatively higher coverage of Lonicera involucrata, Rosa acicularis, Ribes lacustre, Equisetum pratense, Equisetum arvense, Delphinium glaucum, Equisetum scirpoides, Epilobium angustifolium, Pyrola secunda and Hylocomium splendens (Table 11).

In general, the Equisetum sylvaticum subassociation develops on comparatively wetter habitats with higher water tables, whereas the Equisetum pratense subassociation develops on drier habitats with lower water tables. There are also considerable differences in soils characteristics as shown in Table 12. The base saturation and $\mathrm{pH}$ values of the Equisetum pratense subassociation are noticeably higher than they are in the Equisetum sylvaticum subassociation.

The Equisetum sylvaticum subassociation tends to develop on habitats with high water tables and stagnant water where the supply of basic cations is rather limited. On such habitats, a considerable amount of organic matter has accumulated to form peaty deposits. Thus, this subassociation shows a tendency towards development of peat bog vegetation. On the other hand, the Equisetum pratense subassociation develops on habitats where slowly moving seepage water is present, supplying basic cations to the sites and resulting in higher $\mathrm{pH}$ values and higher base saturation.

Forest productivity is also somewhat different between the two subassociations. The Equisetum sylvaticum subassociation shows much lower productivity as average total volume of standing tree stems 

Table 11. Vegetation differences between the two subassociations of the Equisetum association

Species

Picea mariana

Ledum groenlandicum

Salix barclayi

Equisetum sylvaticum

Vaccinium vitis-idaea

Petasites palmatus

Calamagrostis canadensis

Cornus canadensis

Carex vaginata

Deschampsia caespitosa

Carex disperma

Rubus chamaemorus

Aster ciliolatus

Geum rivale

Linnaea borealis

Listera cordata

Pleurozium schreberi

Ptilium crista-castrensis

Tomenthypnum nitens

Lonicera involucrata

Rosa acicularis

Ribes lacustre

Equisetum arvense

Delphinium glaucum

Equisetum pratense

Equisetum scirpoides

Epilobium angustifolium

Pyrola secunda

Hylocomium splendens
E. sylvaticum

subassociation
E. pratense

subassociation

\begin{tabular}{|c|}
\hline $\mathrm{V} / 6 *$ \\
$\mathrm{~V} / 4$ \\
$\mathrm{IV} / 5$ \\
$\mathrm{~V} / 6$ \\
$\mathrm{~V} / 5$ \\
$\mathrm{~V} / 2$ \\
$\mathrm{~V} / 2$ \\
$\mathrm{~V} / 4$ \\
$\mathrm{~V} / 4$ \\
$\mathrm{~V} /+$ \\
$\mathrm{IV} / 4$ \\
$\mathrm{IV} / 4$ \\
$\mathrm{IV} / 1$ \\
$\mathrm{IV} / 1$ \\
$\mathrm{IV} / 1$ \\
$\mathrm{IV} /+$ \\
$\mathrm{V} / 6$ \\
$\mathrm{~V} / 6$ \\
$\mathrm{~V} /+$ \\
\hline $\mathrm{IV} / 3$ \\
\hline
\end{tabular}

$\mathrm{IV} / 3$

III $/ 1$

$\mathrm{I} /+$

$\mathrm{V} / 5$

$\mathrm{I} /+$

$\mathrm{I} /+$

$\mathrm{IV} / 2$

$\mathrm{I} /+$

$\mathrm{II} /+$

$\mathrm{V} / 6$
$\operatorname{III} / 5 *$

II $/+$

II $/ 1$

III $/ 3$

$\mathrm{IV} /+$

$\mathrm{V} /+$

IV $/ 1$

III/+

$\mathrm{V} / 3$

IV $/ 2$

$\mathrm{I} /+$

III / +

III $/+$

III $/ 3$

II $/+$

$\mathrm{V} / 5$

$\mathrm{V} / 5$

III /+

$\mathrm{V} / 4$

$\mathrm{V} / 3$

$\mathrm{IV} /+$

$\mathrm{V} / 6$

$\mathrm{V} /+$

$\mathrm{V} / 6$

$\mathrm{V} / 3$

$\mathrm{IV} /+$

$\mathrm{IV} /+$

$\mathrm{V} / 7$

* The Roman numerals and number in these columns refer, respectively, to presence classes and to average species significance (rounded). 

Table 12. Comparison of soil characteristics in the two subassociations of the Equisetum association.

\section{Soil factors}

Organic horizons:

$\begin{array}{lcc}\mathrm{pH} & 5.2 & 5.8 \\ \text { Base saturation (\%) } & 67.0 & 89.7 \\ \text { Extractable Ca+Mg (m.eq/100 g) } & 90.16 & 124.44 \\ \text { Total nitrogen } & 1.24 & 1.25 \\ \text { C/N ratio } & 33.2 & 27.2 \\ \text { Available phosphorus (ppm) } & 22.66 & 27.11\end{array}$

Mineral horizons:

$\begin{array}{lcc}\mathrm{pH} & 5.4 & 6.5 \\ \text { Base saturation (\%) } & 78.9 & 128.6 \\ \text { Extractable Ca+Mg (m.eq/100 g) } & 24.33 & 26.06 \\ \text { Total nitrogen } & 0.16 & 0.15 \\ \text { C/N ratio } & 20.8 & 21.7 \\ \text { Available phosphorus (ppm) } & 2.97 & 3.85\end{array}$

E. pratense

subassociation
. sylvaticum
subassociation

\section{subassociation}



is $196.7 \mathrm{~m}^{3} / \mathrm{ha}$, ranging from 106.1 to $270.6 \mathrm{~m}^{3} / \mathrm{ha}$, whereas the Equisetum pratense subassociation has an average total volume of standing trees of $346.7 \mathrm{~m}^{3} / \mathrm{ha}$, ranging from 76.7 to $720.0 \mathrm{~m} 3 / \mathrm{ha}$. In fact, the latter subassociation is associated with one of the most productive sites in the northern subalpine regions in Alberta. 

6.3 Plant associations of the upper subzone

In the upper subzone of the subalpine zone, the following two forested associations were recognized and described.

- Picea engelmannil/Abies lasiocarpa - Pedicularis bracteosa association (Pedicularis association)

- Picea engelmannii/Abies lasiocarpa - Empetrum nigrum/

Phyllodoce association (heather association)

6.3.1 Picea engelmannil/Abies lasiocarpa - Pedicularis bracteosa association

6.3.1.1 General description

The Pedicularis association represents xeric to submesic ecosystems of the upper subzone of the subalpine zone (Figure 36). It develops on slightly convex topography of predominantly south to southwest facing slopes at high elevations. Five sample plots were obtained for this association.

The tree layer is moderately well developed but trees tend to occur in groups, with unforested openings between the clumps (Figure 37). The tree layer of "tree islands" is dominated by Picea engelmannii frequently mixed with Pinus contorta. Abies lasiocarpa tends to occur when forest stands are mature. The shrub layer is moderately developed with abundant occurrence of regenerating trees. Of the shrubby species, Salix glauca, Vaccinium caespitosum, Vaccinium membranaceum and Juniperus communis are the major plants. The herb layer is well developed, and is composed mainly of Pedicularis bracteosa, Arnica cordifolia, Linnaea borealis, Hedysarum alpinum, Polygonum viviparum and Pyrola secunda. Most of these same herbs also grow in "open meadows" between tree clumps, but Linnaea borealis, Pyrola secunda, and Vaccinium vitis-idaea tend to be restricted to shaded areas under the tree canopy. 



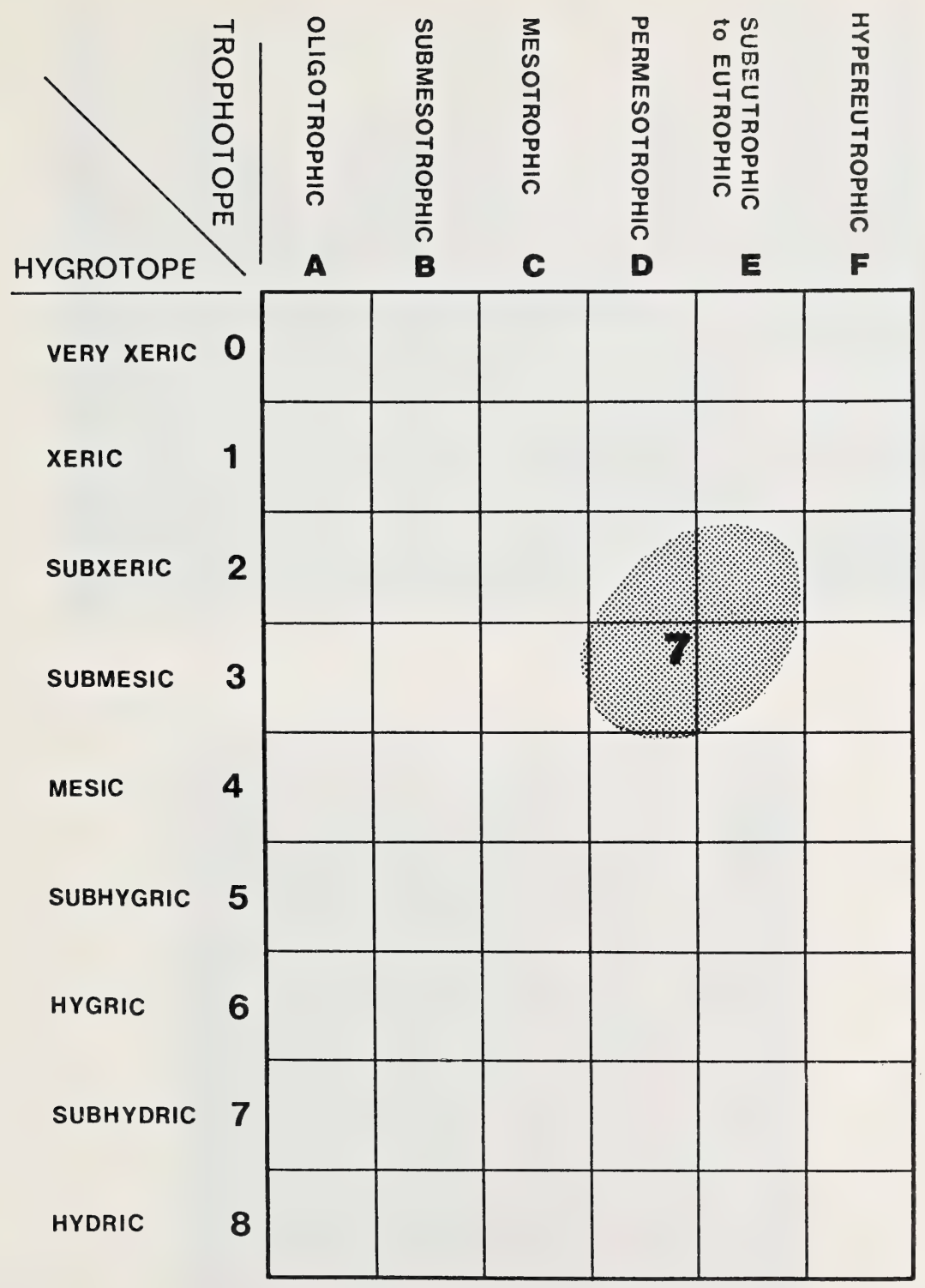

Figure 36. Edatopic position of the spruce/fir-Pedicularis association 


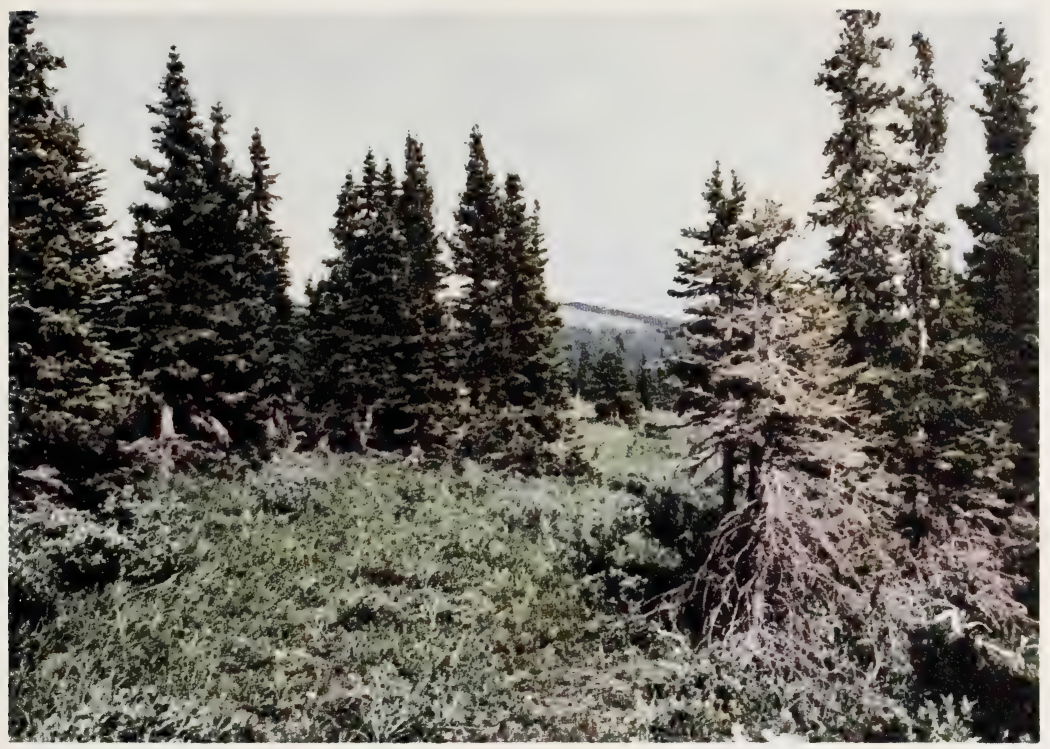

Figure 37. A forest stand of the spruce/fir-Pedicularis association

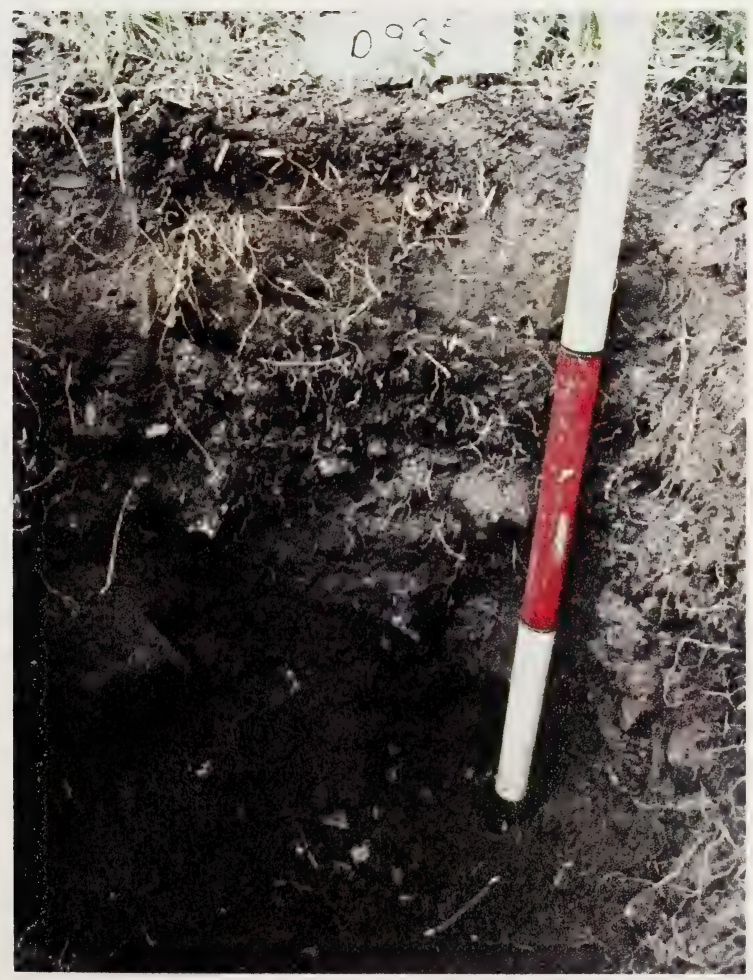

Figure 38. Soil profile of the spruce/fir-Pedicularis association 


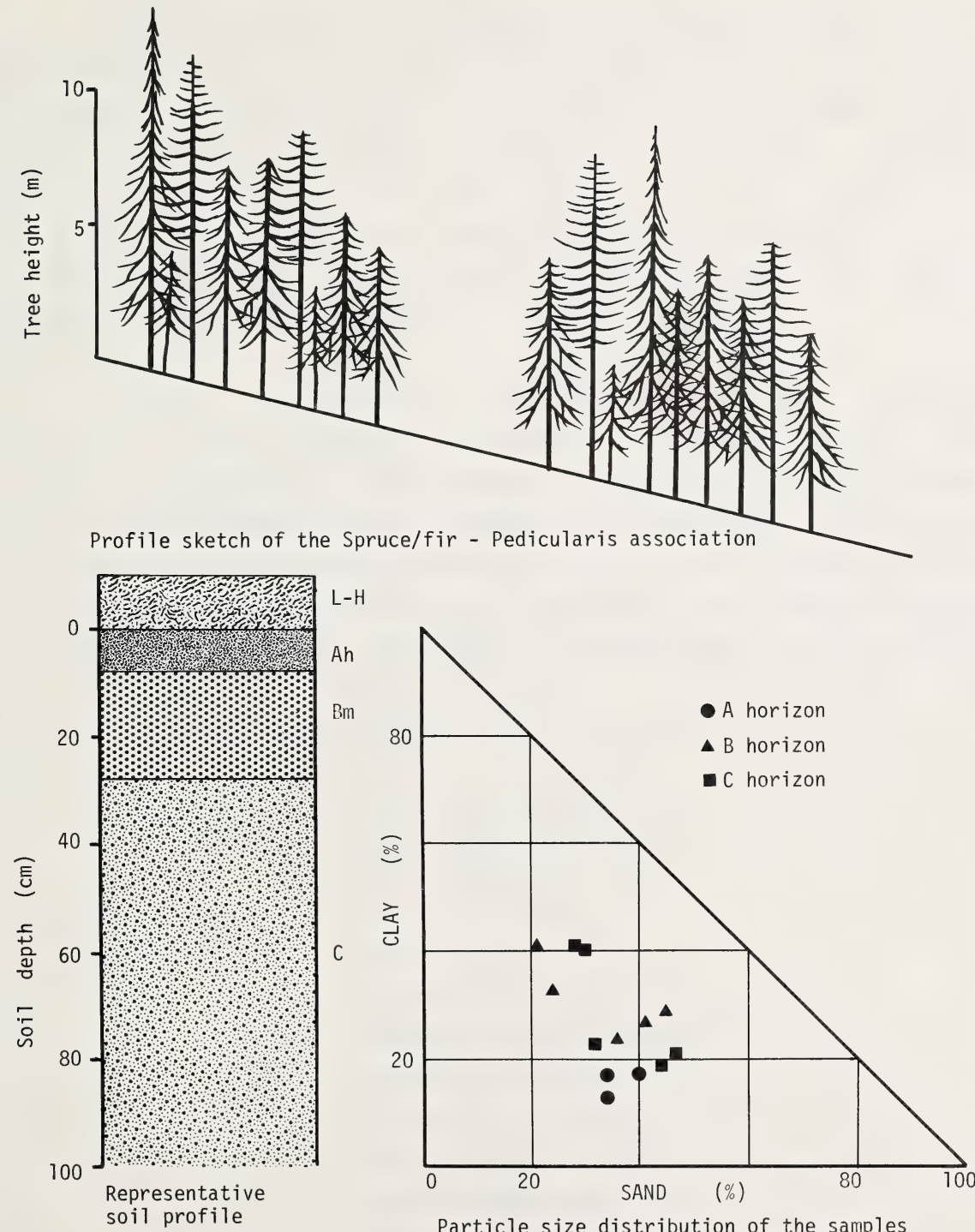

Particle size distribution of the samples representing different horizons

Figure 39. Vegetation and soil profiles and soil particle size distribution of the spruce-fir-Pedicularis association 

Development of the moss layer is moderate, and is dominated by Hylocomium splendens, Dicranum fuscescens, Cladonia pyxidata and Drepanocladus uncinatus.

Soils are fine to moderately fine-textured (Figure 38). Most of the samples were clay or clay loam with some silty loam (Figure 39). Base status is generally high as base saturation averaged 72, 85, 92 and $173 \%$ for the $\mathrm{L}-\mathrm{H}, \mathrm{A}, \mathrm{B}$ and $\mathrm{C}$ horizons, respectively. Averages of $\mathrm{pH}$ are also comparatively high and averaged $4.8,5.2,5.4$ and 6.1 for the $\mathrm{L}-\mathrm{H}, \mathrm{A}, \mathrm{B}$ and $\mathrm{C}$ horizons, respectively. The $\mathrm{C} / \mathrm{N}$ ratio is 33 for the $\mathrm{L}-\mathrm{H}$ horizon and 13 to 19 for the mineral horizons. Available phosphorus is medium ( Table 13).

Forest productivity is low in the Pedicularis association. Total volume of standing tree stems is $214.8 \mathrm{~m}^{3} / \mathrm{ha}$. The major contributor to the volume is Engelmann spruce followed by lodgepole pine. Mean annual increment is $0.93 \mathrm{~m}^{3} / \mathrm{ha}$. Average height of dominant and co-dominant trees is $12.0 \mathrm{~m}$ for lodgepole pine and $13.4 \mathrm{~m}$ for Engelmann spruce and subalpine fir. Site index of Engelmann spruce is $5.0 \mathrm{~m} / 70$ years, and that of lodgepole pine is $8.6 \mathrm{~m} / 70$ years.

6.3.1.2 Characteristic combination of species

$\begin{array}{ll}\text { Tree layer } & \text { Picea engelmannii (CD) } \\ & \text { Pinus contorta (CD) } \\ & \text { Abies lasiocarpa (C) } \\ \text { Shrub layer } & \text { Salix glauca (C) } \\ & \text { Vaccinium membranaceum (I) } \\ & \text { Vaccinium caespitosum (I) } \\ & \text { Juniperus communis (I) } \\ & \text { Potentilla fruticosa (I) } \\ & \text { Pedicularis bracteosa (C) } \\ \text { Herb layer } & \text { Arnica cordifolia (C) } \\ & \text { Hedysarum alpinum (C) } \\ & \text { Polygonum viviparum (C) } \\ & \text { Linnaea borealis (C) } \\ & \text { Elymus innovatus (I) } \\ & \text { Erigeron peregrinus (I) }\end{array}$





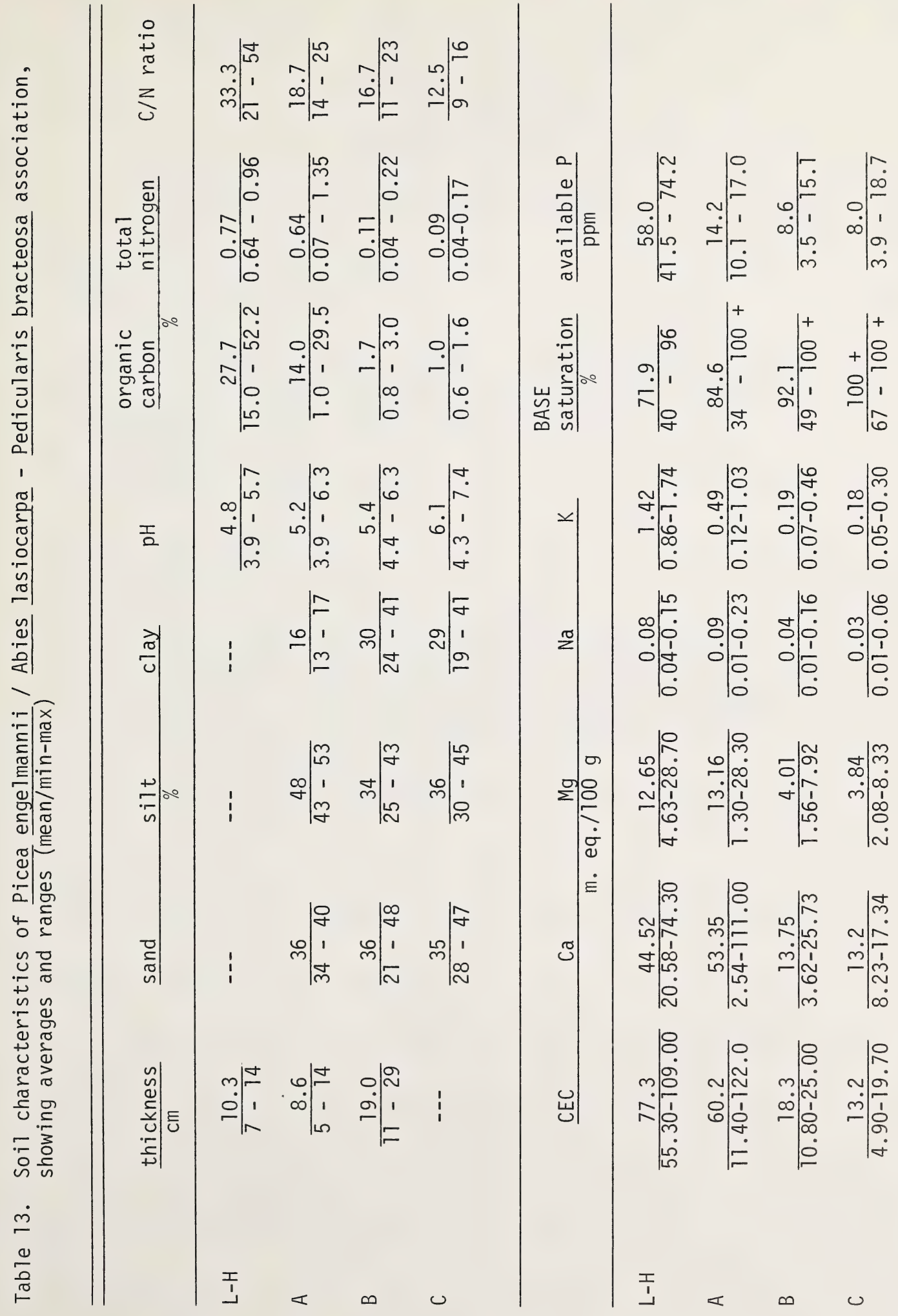




\section{Moss layer Hylocomium splendens (CD) \\ Dicranum scoparium (CD) \\ Peltigera aphthosa (C) \\ Dicranum fuscescens (C) \\ Stereocaulon alpinus (C) \\ Drepanocladus uncinatus (C)}

\subsubsection{Site characteristics}

- topographic position: upper to middle portions of gentle to steep slopes, predominantly facing south to southwest

- altitude range: from 1,500 to $2,000 \mathrm{~m}$ as 1

- slope: 6 to $24^{\circ}$

- aspect: S - SW - (SE)

\subsubsection{Soil characteristics}

- soil classification: Orthic Eutric Brunisol, Orthic to

Eluviated Dystric Brunisol, Orthic Humic Regosol

- soil moisture regime (hygrotope): subxeric to submesic (2-3)

- soil nutrient regime (trophotope): permesotrophic to subeutrophic (D-E)

- depth to groundwater table: no groundwater table detected to a depth of $100 \mathrm{~cm}$

\subsubsection{Successional stage: late intermediate to early advanced}

\subsubsection{Forestry characteristics}

- total stem volume of standing trees, average and range: 214.8

$$
(25.4-275.1) \mathrm{m}^{3} / \mathrm{ha}
$$

- percentage of total stem volume partitioned by species:

Engelmann spruce - $54.9 \%$

1odgepole pine - $44.7 \%$

- regeneration: moderate 

- regeneration by: Engelmann spruce and subalpine fir

- number of trees per hectare: 1,329

- average stand age: 155 years

- average height of dominant and co-dominant trees:

lodgepole pine, $12.0 \mathrm{~m}$;

Engelmann spruce and subalpine fir, $13.4 \mathrm{~m}$

- average height of forest canopy: $9.9 \mathrm{~m}$

- mean annual increment: $0.93 \mathrm{~m}^{3} / \mathrm{ha}$

- site index: 1odgepole pine, $8.6 \mathrm{~m} / 70 \mathrm{yr}$;

Engelmann spruce, $5.0 \mathrm{~m} / 70 \mathrm{yr}$

\subsubsection{Picea engelmannii/Abies lasiocarpa - Empetrum nigrum/ Phyllodoce association}

\subsubsection{General description}

The heather association develops on mesic to subhygric ecosystems of the upper subzone of the subalpine zone (Figure 40). It develops on gentle slopes of various aspects, but tends to occur microtopographically on slightly concave slopes where snow accumulates. Six sample plots represent this association.

The tree layer develops in a clumped pattern with openings between the clumps (Figure 41). The tree layer is dominated by Picea engelmannii, followed by Abies lasiocarpa. Pinus contorta is rarely present. The shrub layer, although strongly dominated by regenerating trees, includes Juniperus communis, Vaccinium membranaceum, Rhododendron albiflorum and Vaccinium scoparium. The herb layer is well developed. However, there are some difference in vegetation structure within the openings and under tree clumps. The vegetation in openings consists mainly of heather plants such as Cassiope tetragona, Phyllodoce empetriformis and Phyllodoce glanduliflora, whereas the vegetation under tree clumps is dominated by Cornus canadensis, Vaccinium vitis-idaea and Linnaea borealis which are basically forest plants. The moss layer is moderately developed, and is dominated by Pleurozium schreberi and Dicranum scoparium followed by Barbilophozia hatcheri, Peltigera aphthosa, Dicranum fuscescens and Polytrichum juniperinum. 


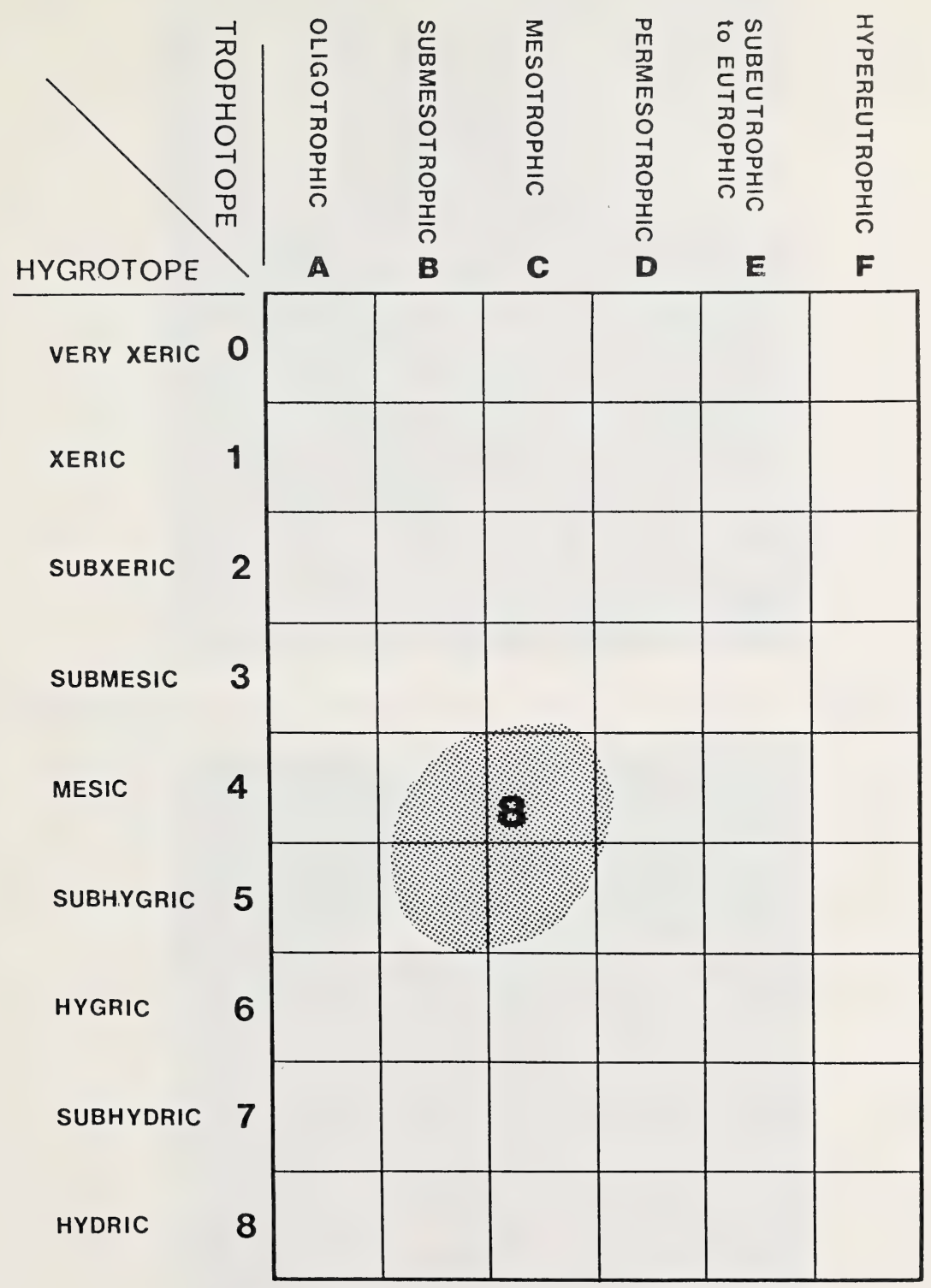

Figure 40. Edatopic position of the spruce/fir-heather association 


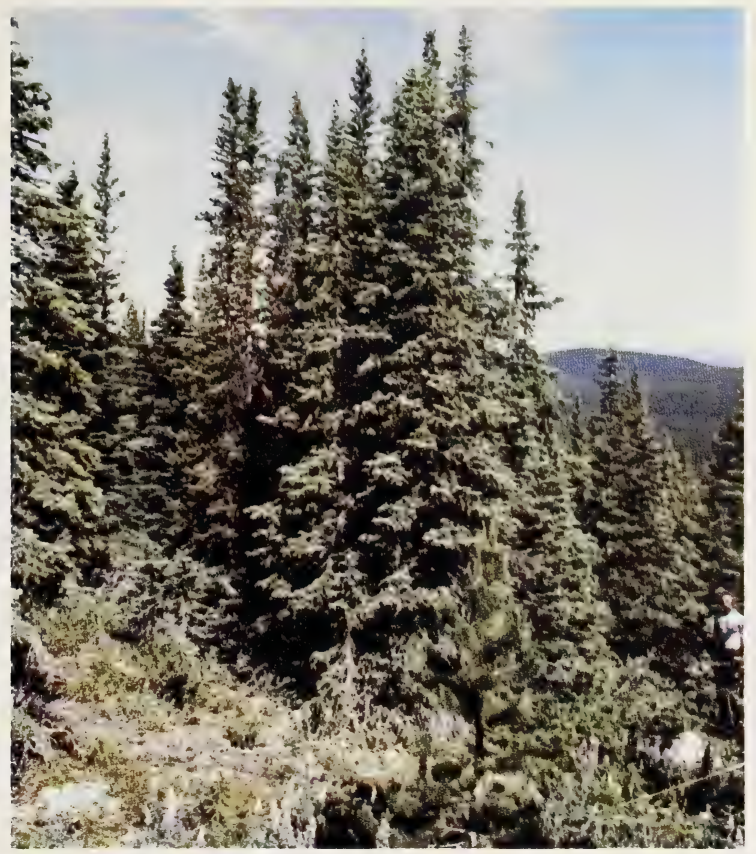

Figure 41. A forest stand of the spruce/fir-heather association

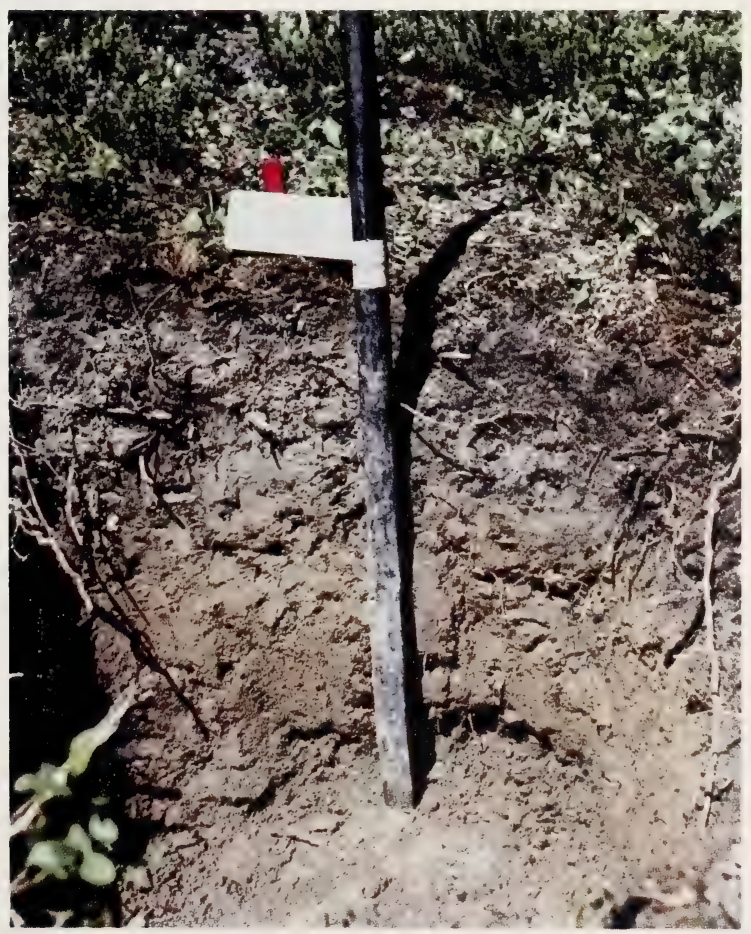

Figure 42. Soil profile of the spruce/fir-heather association 

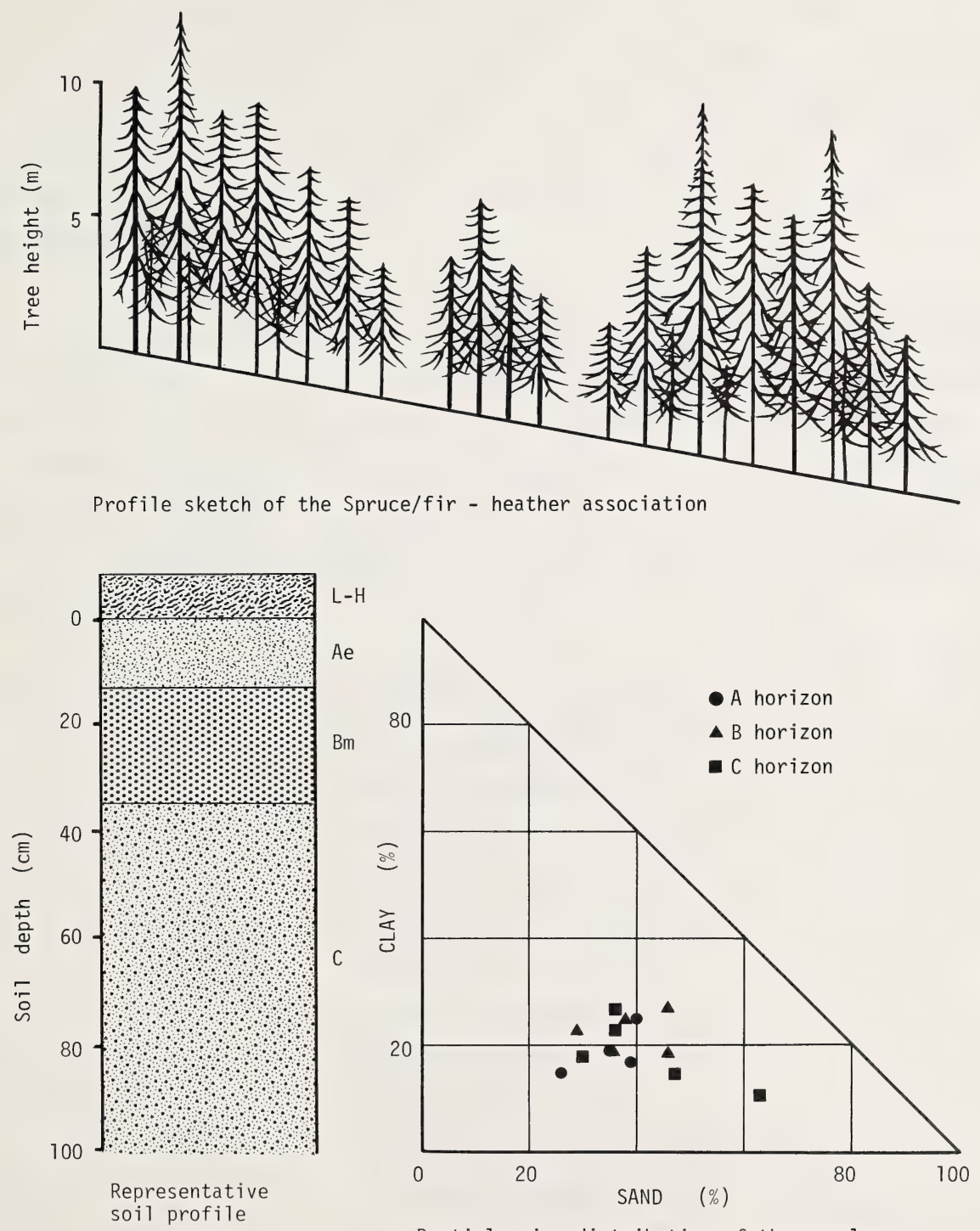

Particle size distribution of the samples representing different horizons

Figure 43. Vegetation and soil profiles and soil particle size distribution of the spruce/fir-heather association 

Soils are moderately fine to moderately coarse-textured (Figure 42). Most soil samples are loam, with some sandy loam, sandy clay loam and silty loam (Figure 43). Base status of this association is low as averages of base saturation are 39, 32, 52 and $78 \%$ for the L-H, A, B and C horizons, respectively. The $\mathrm{pH}$ averages are 4.1, 4.1, 4.5 and 5.1 for the $\mathrm{L}-\mathrm{H}, \mathrm{A}, \mathrm{B}$ and $\mathrm{C}$ horizons, respectively. C/N ratios are rather low as they are 23 for the $\mathrm{L}-\mathrm{H}$ horizon and 12 to 16 for the mineral horizons. Available phosphorus is relatively high in this association (Table 14).

Forest productivity is low with a total volume of standing stems of $175.5 \mathrm{~m}^{3} / \mathrm{ha}$ on average, consisting mainly of Engelmann spruce, followed by subalpine fir. Average height of dominant and co-dominant trees is $10.9 \mathrm{~m}$ for lodgepole pine and $13.0 \mathrm{~m}$ for Engelmann spruce and subalpine fir; average height of the forest canopy is $10.7 \mathrm{~m}$. Stand age averaged 113 years. Mean annual increment was recorded as $1.25 \mathrm{~m}^{3} / \mathrm{ha}$.

6.3.2.2 Characteristic combination of species

$\begin{array}{ll}\text { Tree layer } & \text { Picea engelmannil (CD) } \\ & \text { Abies lasiocarpa (CD) } \\ \text { Shrub layer } & \text { Juniperus communis (C) } \\ & \text { Vaccinium membranaceum (I) } \\ & \text { Rhododendron albiflorum (I) } \\ \text { Herb layer } & \text { Empetrum nigrum (CD) } \\ & \text { Cornus canadensis (C) } \\ & \text { Vaccinium vitis-idaea (C) } \\ & \text { Pyrola secunda (C) } \\ & \text { Phyllodoce empetriformis (I) } \\ & \text { Phyllodoce glanduliflora (I) } \\ & \text { Cassiope tetragona (I) } \\ & \text { Arnica latifolia (I) } \\ & \text { Pleurozium schreberi (CD) } \\ & \text { Hylocomium splendens (CD) } \\ & \text { Dicranum scoparium (C) } \\ & \text { Barbilophozia hatcheri (C) } \\ \text { Moss layer } & \end{array}$





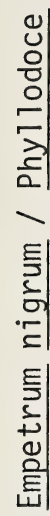

愛

ng:

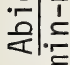

-

:

的

这

ฐ্ّ

$\div 2$

o

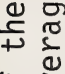

4

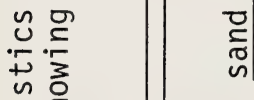

站

政

Uू.

(1)

$0 . \frac{\pi}{4}$

$-8$

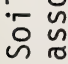

$\stackrel{5}{7}$

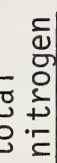

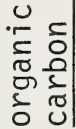

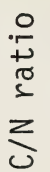

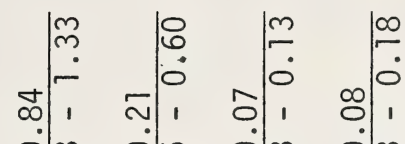

o

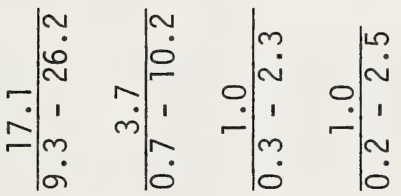

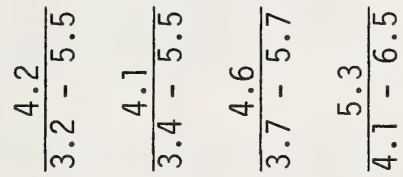

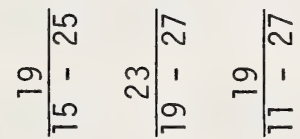

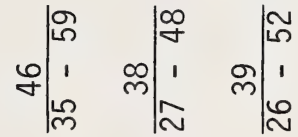

:

:

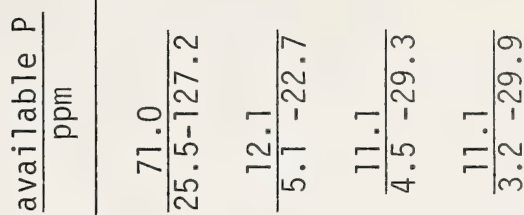

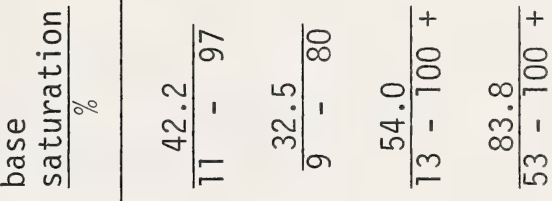

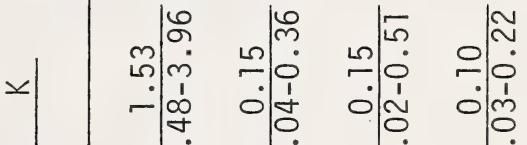

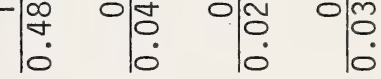

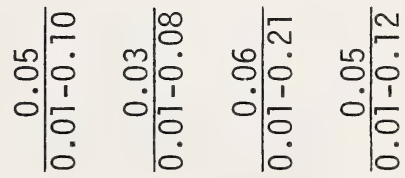

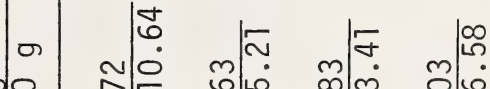

잉 №

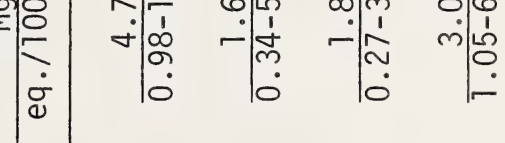

$\dot{E}$

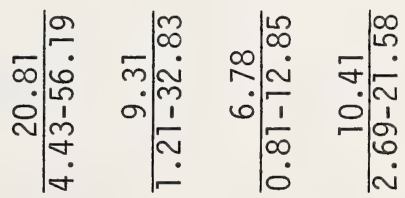

๘

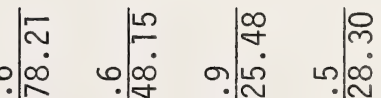

嵌 :

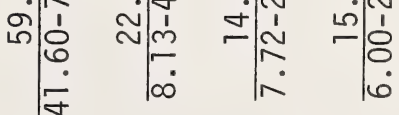




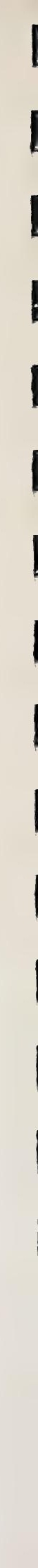




\subsubsection{Site characteristics}

- topographic position: mid slope to slope base, slightly concave microtopography

- altitude range: from approximately 1,600 to $2,000 \mathrm{~m}$

- slope: level to $22^{\circ}$

- aspect: variable

\subsubsection{Soil characteristics}

- soil classification: Orthic Dystric Brunisol

- soil moisture regime (hygrotope): mesic to subhygric (4-5)

- soil nutrient regime (trophotope): submesotrophic to mesotrophic $(B-C)$

- depth to groundwater table: no groundwater table detected to a depth of $100 \mathrm{~cm}$

6.3.2.5 Successional stage: advanced to mature

\subsubsection{Forestry characteristics}

- total stem volume of standing trees, average and range: 175.5

$$
(57.6-330.3) \mathrm{m}^{3} / \mathrm{ha}
$$

- percentage of total stem volume partitioned by species:

Engelmann spruce - $64.0 \%$

lodgepole pine $-27.6 \%$

subalpine fir - $8.5 \%$

- regeneration: moderate

- regeneration by: Engelmann spruce and subalpine fir

- average number of trees per hectare: 1,349

- average stand age: 113 years

- average height of dominant and co-dominant trees:

lodgepole pine, $10.9 \mathrm{~m}$;

Engelmann spruce and subalpine fir, $13.0 \mathrm{~m}$

- average height of forest canopy: $10.7 \mathrm{~m}$

- average mean annual increment: $1.25 \mathrm{~m}^{3} / \mathrm{ha}$

- site index: lodgepole pine, $9.7 \mathrm{~m} / 70 \mathrm{yr}$;

Engelmann spruce, $6.3 \mathrm{~m} / 70 \mathrm{yr}$; subalpine fir, $6.2 \mathrm{~m} / 70 \mathrm{yr}$ 


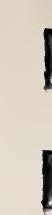

I

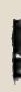

।

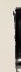

1

।

।

|

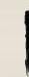




\section{DISCUSSION}

The previous section described eight forested associations of the subalpine zone in Alberta, with six associations representing forest ecosystems of the lower subzone and two representing the upper subzone. In this section discussion is concentrated mainly on the six associations of the lower subzone because they are not only more important from the forestry point of view but they also cover a fairly wide range of habitat variations, which makes discussion more meaningful.

7.1 Vegetation similarity among the associations

Vegetational similarities among the six associations were calculated (Table 15), based on Sфrensen's similarity coefficient (Sфrensen 1948) as modified by Dah1 (1956). Based on the coefficients, a dendrogram was constructed to demonstrate the similarities diagrammatically (Figure 44).

In the dendrogram, the Elymus and Shepherdia associations show a close affinity to each other, forming a cluster with a similarity coefficient of 0.77 . The cluster represents ecosystems that develop on comparatively dry habitats. The Rhododendron association and the moss association also form a cluster with a similarity coefficient of 0.75 . This cluster represents ecosystems that develop on mesic habitats. The alder association, which develops on mesic to subhygric habitats, shows some affinity to the cluster that contains the Rhododendron and moss associations. The Equisetum association joins the cluster that contains the Rhododendron, moss and alder associations at the level of 0.54 similarity coefficient. Finally, all the clusters are connected with a similarity coefficient of 0.40 , completing the linkage of all six forested associations of the lower subzone. The sequence of associations portrayed by the dendrogram (Figure 44) coincides, in a general way, with a hygrotopic gradient, as outlined in more detail in Section 7.2 below. 


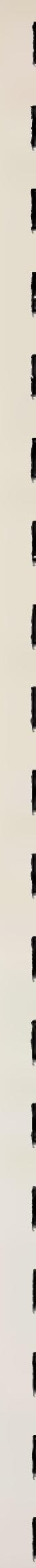




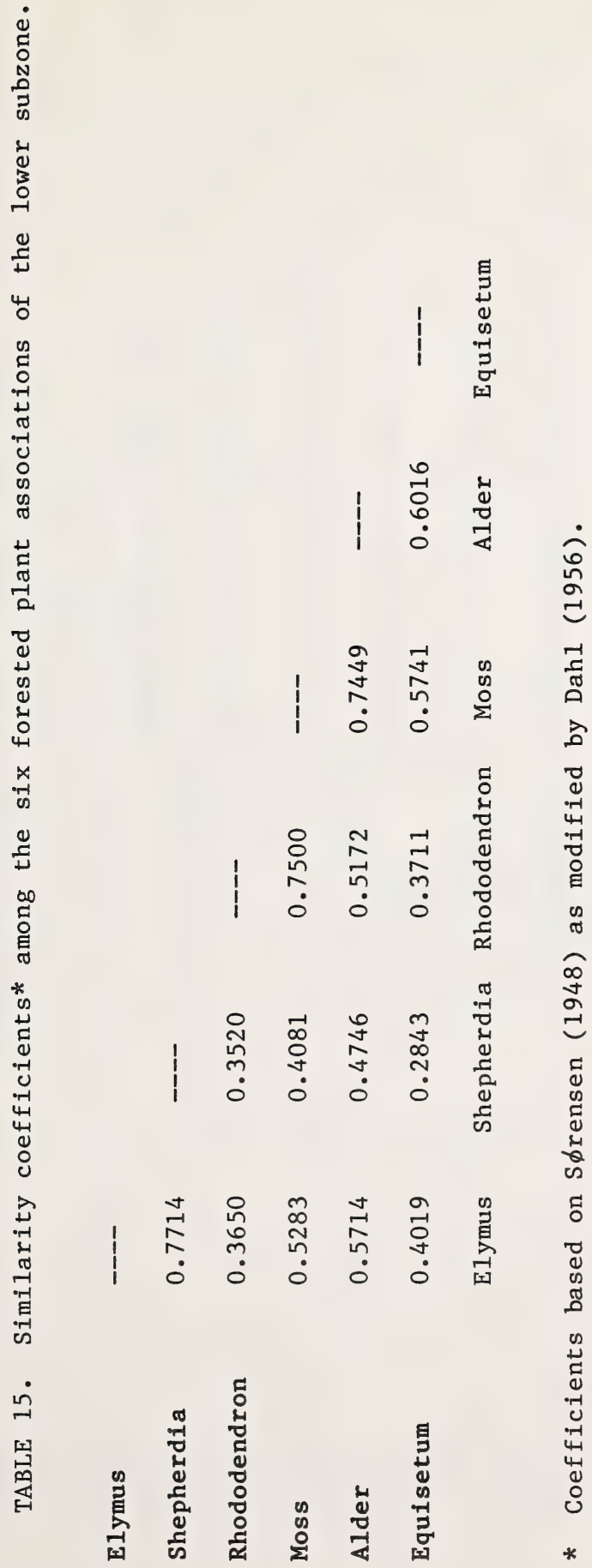




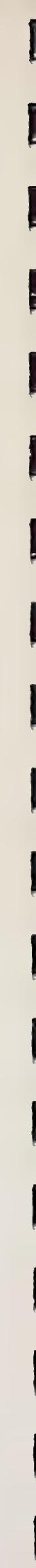




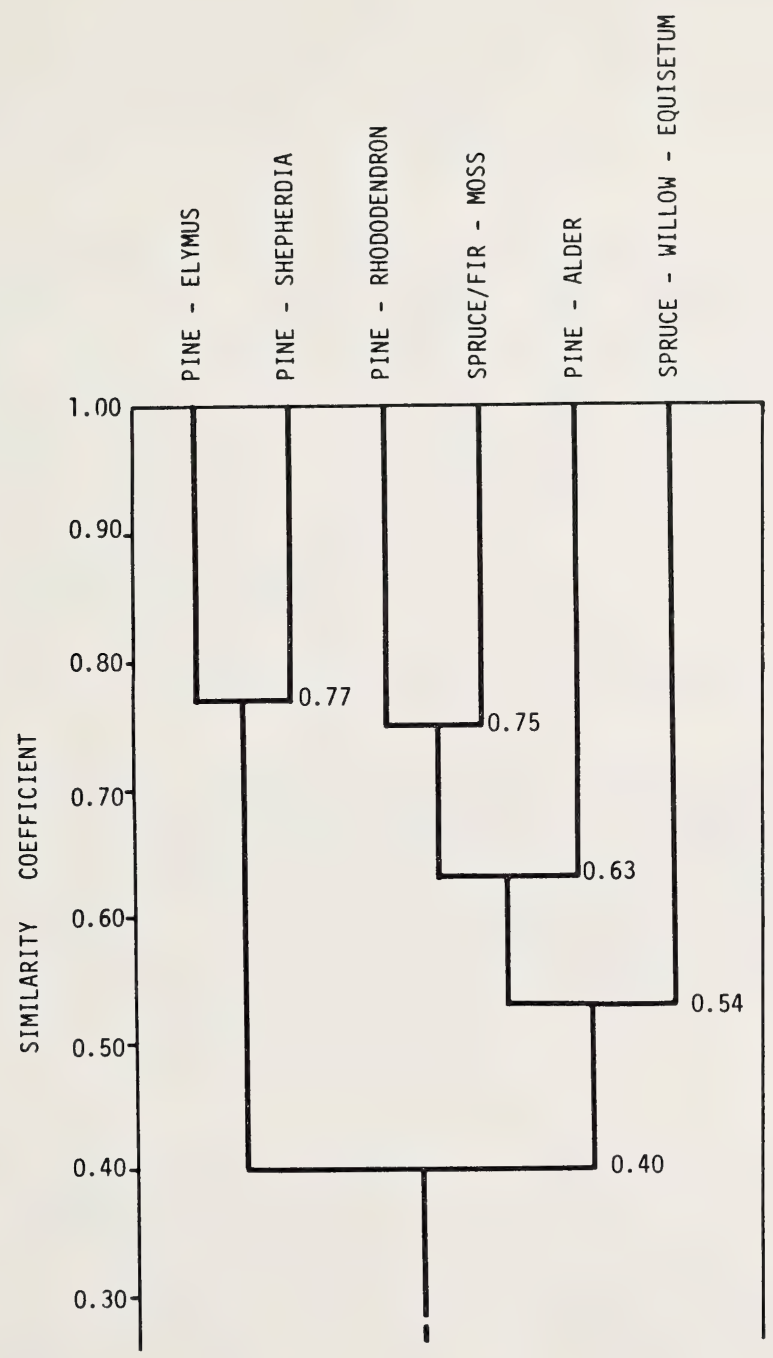

Figure 44. Dendrogram showing vegetational similarity among the six forested plant associations of the lower subzone. 


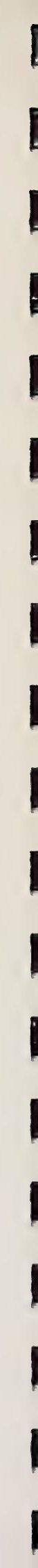


7.2 Sequence of associations in relation to moisture regime

Hygrotope is, in essence, moisture available to plants and it can be assessed on the basis of topographic position, soil texture, field moisture of soils, and responses of plants to available moisture. Some relationships between hygrotope and forested associations of the subalpine zone are summarized in Figure 45.

The Elymus association, which occurs on upper slopes or on we11 drained soils, appears on the driest portion of the hygrotope scale, while the Equisetum association, which develops in valley bottoms or in concave topography where water tends to collect, appears on the wetter portions of the hygrotope scale. Other forested associations are arranged between these two extremes according to their moisture requirements (Figure 45).

\subsection{Sequence of associations in relation to nutrient gradient}

Trophotope refers to the total availability of nutrients to plants and can be assessed by integrating information on topographic position, kind of parent material, chemical characteristics of soils, presence or absence of seepage water, and growth responses of plants. Some relationships between trophotope and forested associations of the subalpine zone are shown in Figure 46.

The trophotopic sequence of the associations shows a very different trend from that of the hygrotope. In general, ecosystems that develop on drier and wetter sites show a higher trophotope while those that occur on mesic sites tend to show a lower trophotope. Thus, the Rhododendron association shows the lowest trophotope and the moss association the second lowest. On the other hand, the Elymus association and the Equisetum association show the highest trophotope. The Shepherdia association and the alder association are in middle positions. 


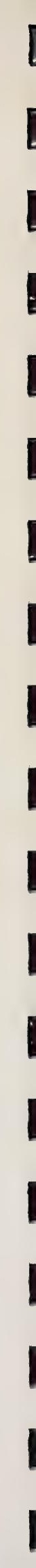




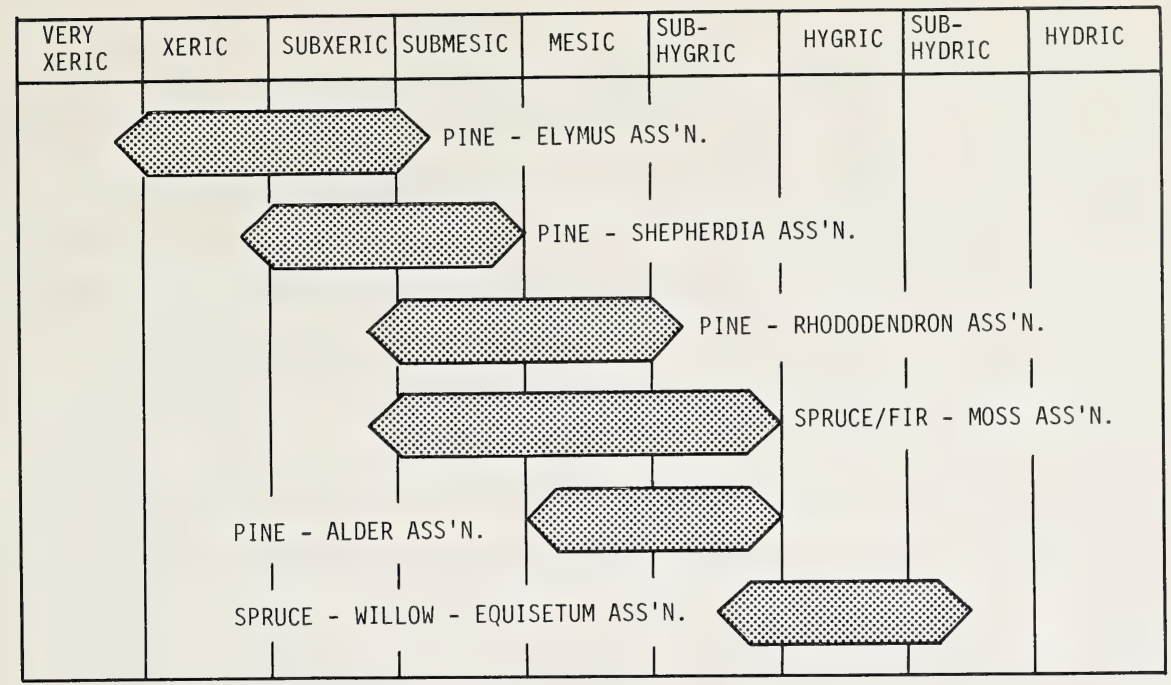

Figure 45. Hygrotopic sequence of the six forested plant associations of the lower subzone

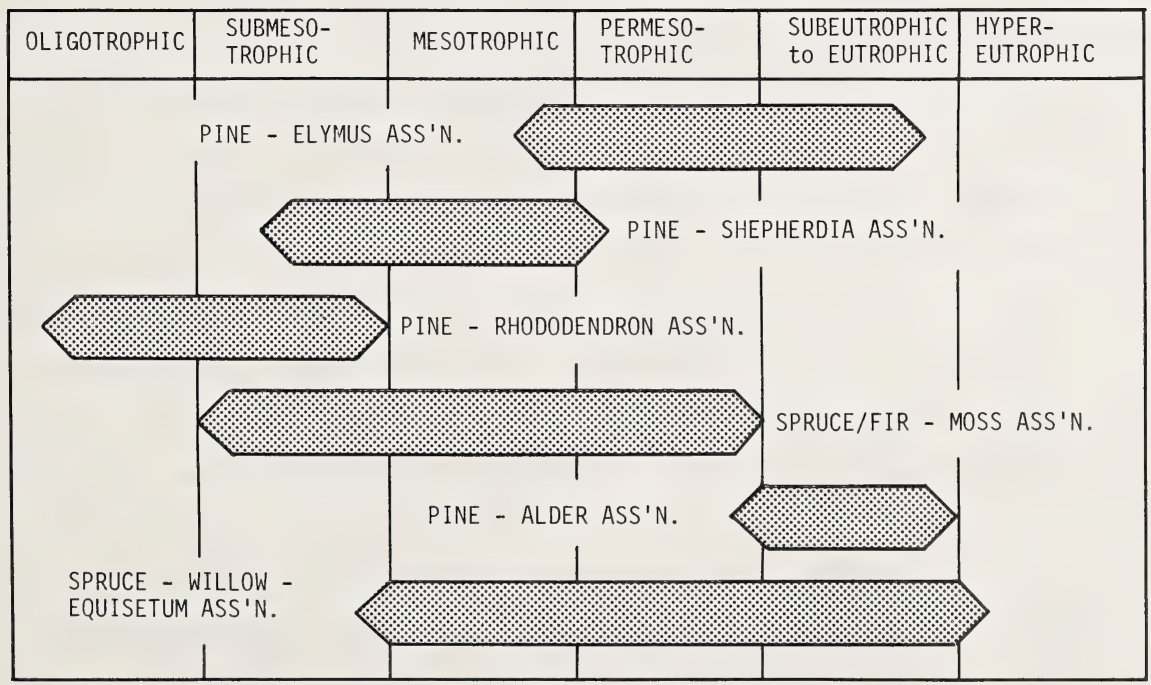

Figure 46. Trophotopic sequence of the six forested plant associations of the lower subzone 


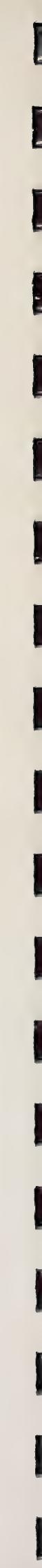


The overall trend of relations between the hygrotope and trophotope is somewhat different from the case in coastal British Columbia. In ecosystems of the coastal forests, hygrotope and trophotope are generally positively correlated (Kojima 1971, Kojima and Krajina 1975), but in this study, the relationship is not necessarily so. The contrasting circumstances may be related to differences in climatic regimes. In the coastal region of British Columbia, a well developed oceanic climate, which is mild and humid, accelerates leaching of the soils to result in lower base status and lower $\mathrm{pH}$, unless some enrichment of bases takes place. However, in habitats such as valley bottoms and seepage discharge sites, basic cations are continuously supplied by seepage to result in enrichment of bases and these cations eventually increase the base status as well as $\mathrm{pH}$. Thus, in a coastal climate, a trophotope that is highly contributed to by basic cations shows a positive correlation with the amount of seepage and, in turn, with hygrotope.

In contrast, in interior regions such as the present study area, the climate is typically continental, which is comparatively warmer and drier than the coastal climate. A high rate of potential evapotranspiration is expected at inland locations and if evapotranspiration exceeds precipitation there will be a climatic water deficit. Under such climatic characteristics, water supplied by rain may not percolate through the soil system to remove the basic cations. Therefore, leaching of soils will be extremely slow or may not take place at all. This would be particularly true for sites of upper slopes and ridge crests which receive a relatively high rate of insolation and strong wind exposure. Thus, the upper slopes would not be subjected to strong leaching in the interior regions. However, on mesic sites on middle portions of slopes, the rate of evapotranspiration may be slightly lower than on upper slopes because of less exposure to wind and lower soil temperature due to better development of a forest canopy. In such mesic sites, precipitation may slightly exceed the rate of potential evapotranspiration so that there is an initiation of soil leaching. Once leaching is in progress there is a lowering of base status and $\mathrm{pH}$ of the soils. On the other hand, 


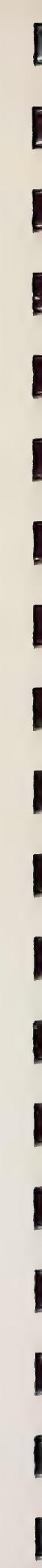


in habitats of valley bottoms where seepage tends to collect, basic cations would be supplied continuously; the result would be an enrichment of cations, an increase of base status and an increase of soil pH.

\subsection{Edaphic relationships of the associations}

To summarize the moisture and nutritional characteristics of the six forested associations of the lower subzone, edatopic relationships are presented in a composite edatopic grid matrix (Figure 47).

In the matrix, the Elymus association appears in the upper right corner, indicating its occurrence on dry and base-rich habitats. The Shepherdia association is situated at the lower left of the Elymus association, suggesting that its habitat is slightly more moist and less rich in base status. The Rhododendron association is situated in the upper left of the matrix as it represents habitats that are moist and poor in nutrients, in particular the basic cations. The moss association covers a fairly large area of the matirix, situated almost at its centre and representing mesic habitats with moderate nutritional status. The moss association is the most common of the forested associations in the study area, showing a fairly wide amplitude to habitat variation. Because of this wide amplitude, the moss association was divided into two subassociations, the Ledum groenlandicum subassociation and the typical subassociation, the former representing poorer and more acidic habitats with poorer tree growth and the latter representing habitats comparatively richer and less acidic. The alder association shows up in the lower right portion of the matrix, somewhat below the moss association. The alder association occurs on moderately moist and fertile habitats. Presumably because of symbiotic nitrogen fixation, the soils of the alder association are usually rich in nitrogen. The Equisetum association appears in the lower right portion of the matrix, indicating that its occurrence is confined to the most moist and base-rich habitats. 


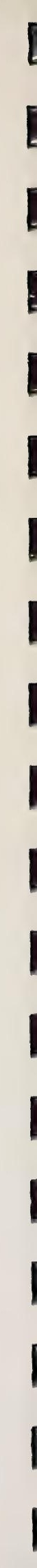




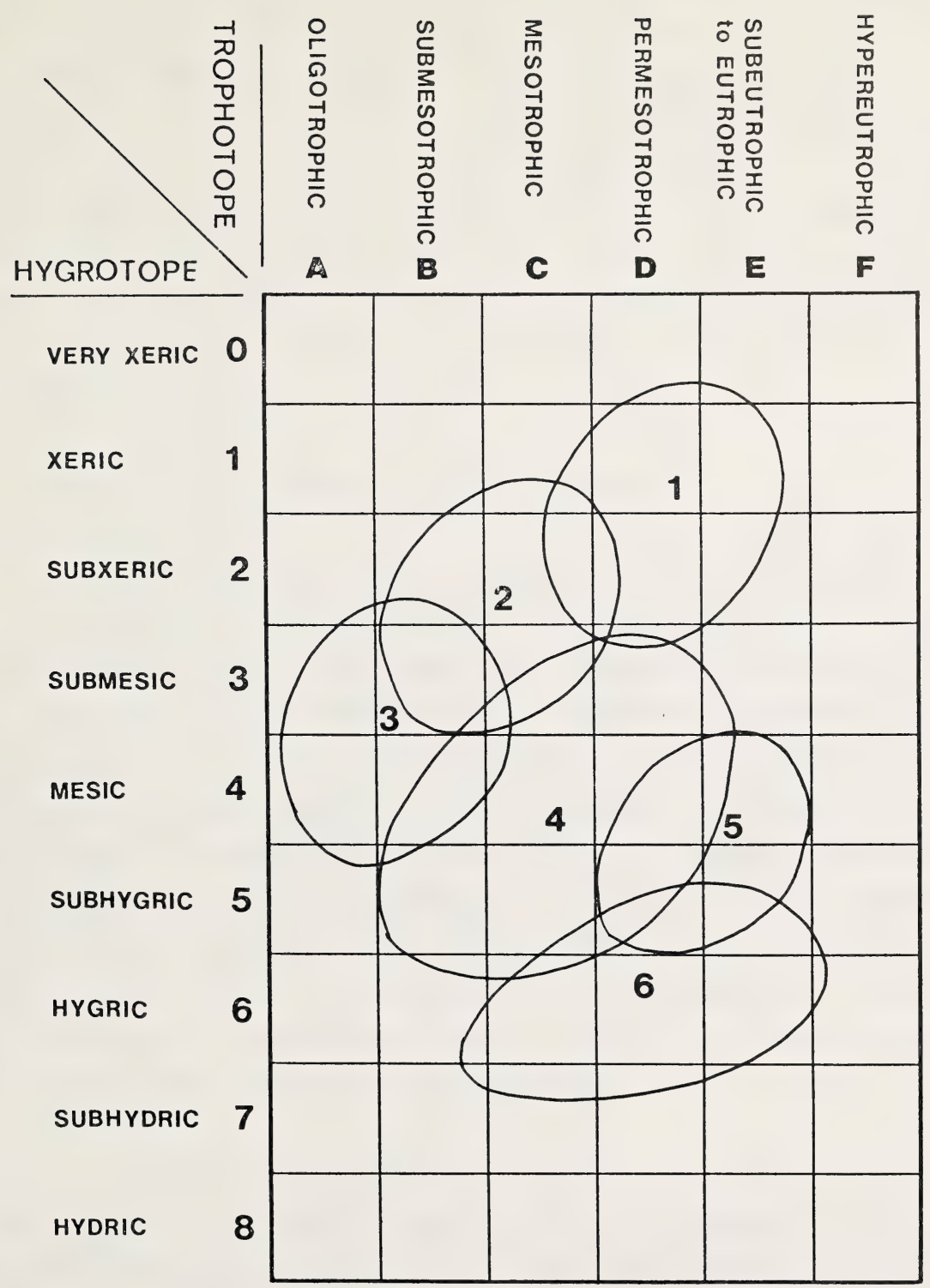

Figure 47. Composite edatopic positions of the six forested plant associations of the lower subzone. 1. pine-Elymus association; 2. pine-Shepherdia association; 3. pine-Rhododendron association; 4. spruce/fir-moss association; 5. pine-alder association; and 6. sprucewillow-Equisetum association 
The associations in the matrix tend to be overlapped with each other. Boundaries of the associations are, by no means, clear-cut; vegetation changes from one association to another, intergrading to some extent. It should also be noted that the present study includes only forested associations. However, in the lower subzone of the subalpine zone, there are numerous kinds of non-forested associations, which were not described in this study nor shown in the matrix. For this reason, some unoccupied space occurs in the matrix. If all associations, forested or unforested, were included then the matrix would be completely filled.

\subsection{Base status of soils in the associations}

Base saturation is the quotient of basic cations $(\mathrm{Ca}+\mathrm{Mg}+$ $\mathrm{Na}+\mathrm{K}$ ) divided by cation exchange capacity. When all the potential cation holding sites of soil particles are occupied by basic cations, the base saturation is $100 \%$. It is, therefore, employed to measure abundance of basic cations in the soil. It is an indicator of soil fertility to some extent. Base saturation of the six forested associations is summarized in Table 16. The Elymus association and the Equisetum association exhibit high base status, whereas the Rhododendron association has the lowest. The sequence of the associations in Table 16 coincides with the trophotopic sequence, as drier and wetter associations have higher base status and mesic associations tend to be low in base status.

A similar tendency is recognized in $\mathrm{pH}$ values. As shown in Figure 48, the Elymus association and Equisetum association have the highest $\mathrm{pH}$ values for any of the soil horizons. On the other hand, the Rhododendron association shows the lowest $\mathrm{pH}$ values. Because $\mathrm{pH}$ is an inverse expression of the amount of hydrogen ions in a solution and because hydrogen ions are antagonistic to basic cations in the soil system, it can be expected that $\mathrm{pH}$ will be positively correlated with the amount of basic cations, as expressed by base saturation. 
TABLE 16. Base saturation, total nitrogen and available phosphorus in different soil horizons of the six forested plant associations in the lower subzone.

Association number*
1
2
3
4
5
6

\begin{tabular}{lcccccc}
\hline Base saturation $(\%)$ & & & & & \\
L-H & 99 & 63 & 16 & 37 & 49 & 80 \\
A & 130 & 86 & 44 & 26 & 66 & 77 \\
B & 96 & 64 & 22 & 49 & 77 & 109 \\
C & 219 & 98 & 66 & 96 & 96 & 106 \\
\hline Total nitrogen $(\%)$ & 0.56 & 0.93 & 0.89 & 0.99 & 1.37 & 1.27 \\
L-H & 0.98 & 0.04 & 0.11 & 0.13 & 0.14 & 0.64 \\
A & 0.02 & 0.06 & 0.07 & 0.11 & 0.08 & 0.11 \\
B & 0.09 & 0.05 & 0.06 & 0.06 & 0.09 & 0.20 \\
C & 15 & 9 & 18 & 11 & 7 & 3 \\
\hline Available phosphorus & $(\mathrm{ppm})$ & & 13 & 7 & 6 & 4 \\
L-H & 80 & 49 & 103 & 80 & 60 & 22 \\
A & 10 & 5 & 16 & 9 & 9 & 6 \\
B & 6 & 6 & 13 & & & \\
\hline
\end{tabular}

* 1. pine-E1ymus association;

2. pine-Shepherdia association;

3. pine-Rhododendron association; 4. spruce/fir-moss association;

5. pine-alder association; and 6. spruce-willow-Equisetum association. 
7.6 Total nitrogen in soils of the associations

Table 16 summarizes the amount of total nitrogen in soils of the six forested associations. The same data are presented in Figure 48 but in a slightly different way so that the nitrogen content of the L-H horizons can be compared with mineral horizons.

In the L-H horizons, the amount of total nitrogen tends to increase from dry to wet associations, with highest value in the alder association. The amount of nitrogen in soils is highly correlated with the amount of organic matter as nitrogen is usually included in the organic compounds. In the Elymus association on dry habitats, decomposition of organic matter appears to be rapid, resulting in relatively low organic matter and consequently less nitrogen. On the other hand, in the Equisetum association that develops on moist habitats where soils are poorly drained and aerated, decomposition of organic matter is relatively slow, resulting in an increase of organic matter as well as nitrogen in the soils. In the alder association, which has the highest nitrogen content of the six forested associations in the lower subzone, some enrichment of nitrogen is expected due to symbiotic nitrogen fixation. Abundant nodules on root systems of alder were commonly observed in this association.

In the mineral horizons, relatively high nitrogen contents in the Elymus and Equisetum associations may have resulted from a comparatively well developed Ah horizon in these associations.

7.7 Available phosphorus in soils of the associations

Table 16 summarizes the recorded amounts of available phosphorus in soils of the six associations and Figure 48 illustrates relative magnitudes of available phosphorus for the associations.

In general, the amount of available phosphorus is higher in mesic habitats with highest amounts in the moss association (Table 16). It decreases towards both xeric and hygric ends of the hygrotope scale, 



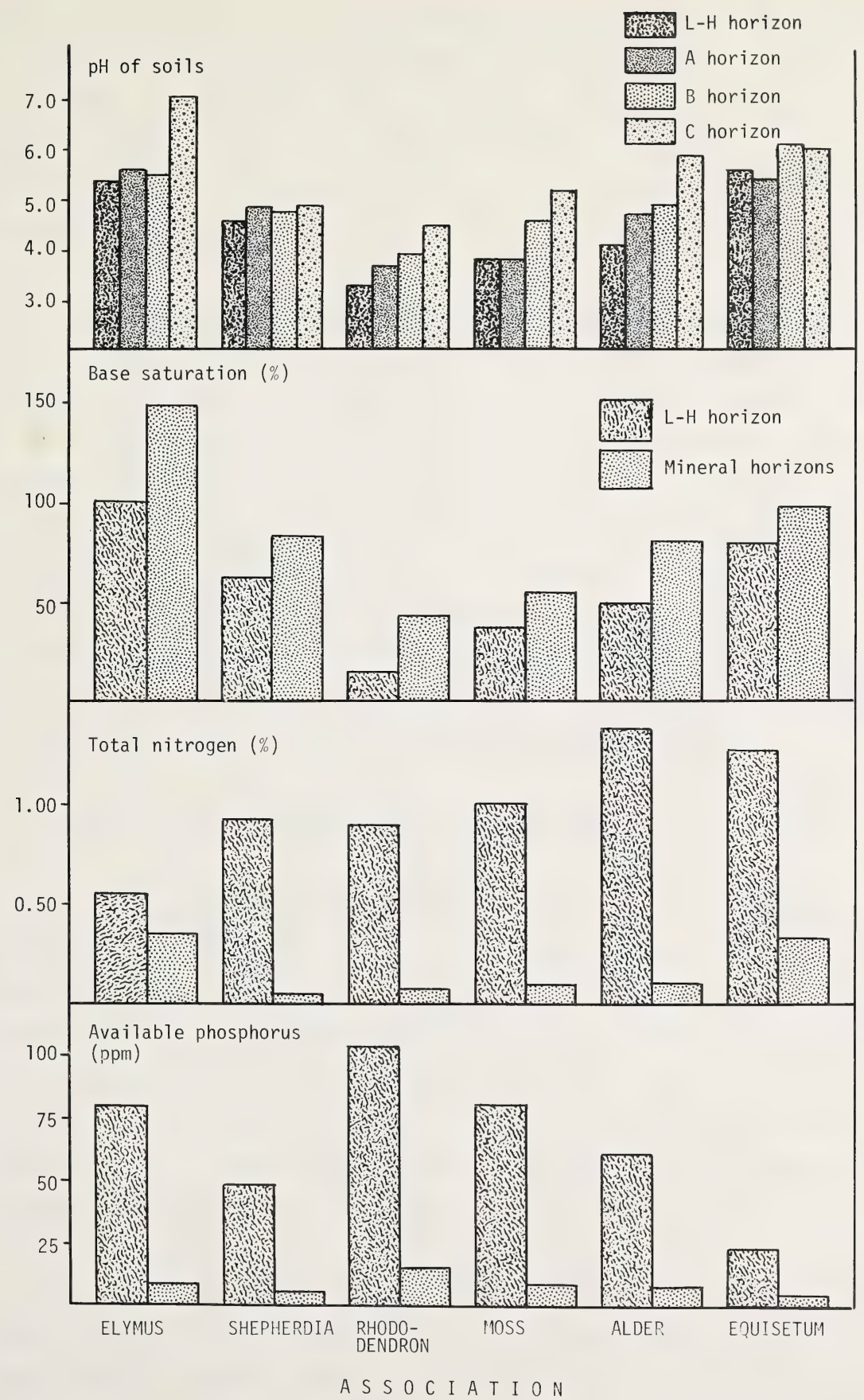

Figure 48. Soil characteristics of the six forested plant associations of the lower subzone 
with the exception of the Shepherdia association where the amount of available phosphorous is lowest of any of the forested associations (Table 16, Figure 48). A very similar tendency has been recorded for the coastal forests of British Columbia, where xeric and hygric ecosystems showed the lowest amount of available phosphorus and mesic ecosystems the highest (Kojima 1971).

Available phosphorus is a soluble form of phosphorus which can be immediately utilized by plants. The amount of available phosphorus is highly variable and is affected by various factors such as $\mathrm{pH}$ of the soil solution, amount of iron and aluminum oxides, amount of basic cations, and kinds and magnitudes of microbial activities. However, in general, when soil is rich in basic cations and with high $\mathrm{pH}$, phosphorus tends to combine with calcium to form calcium phosphate which is an insoluble form of phosphorus. The net result is a decrease in amount of available phosphorus. It is likely for this reason that base-rich habitats, such as the Elymus and Equisetum associations, have low amounts of available phosphorus.

\subsection{Forest productivity of the associations}

of all forested associations in the northern subalpine regions of Alberta, the alder association supports the highest total tree stem volume per hectare, highest average tree height, highest mean annual increment, highest average volume per tree, and highest site indices of lodgepole pine and subalpine fir (Table 17 and Figures 49 and 50). Such a high productivity for this association seems to have resulted from the high nutritional status of soils in these ecosystems, as discussed in previous sections.

The moss association appears to be the second most productive association. It has medium values in parameters such as total tree stem volume, average height of trees and average volume per tree. Environmental characteristics of the moss association are also rated medium for most parameters. 


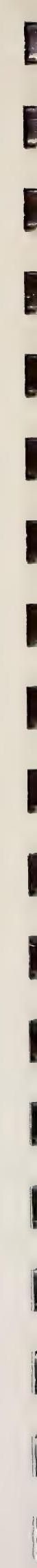




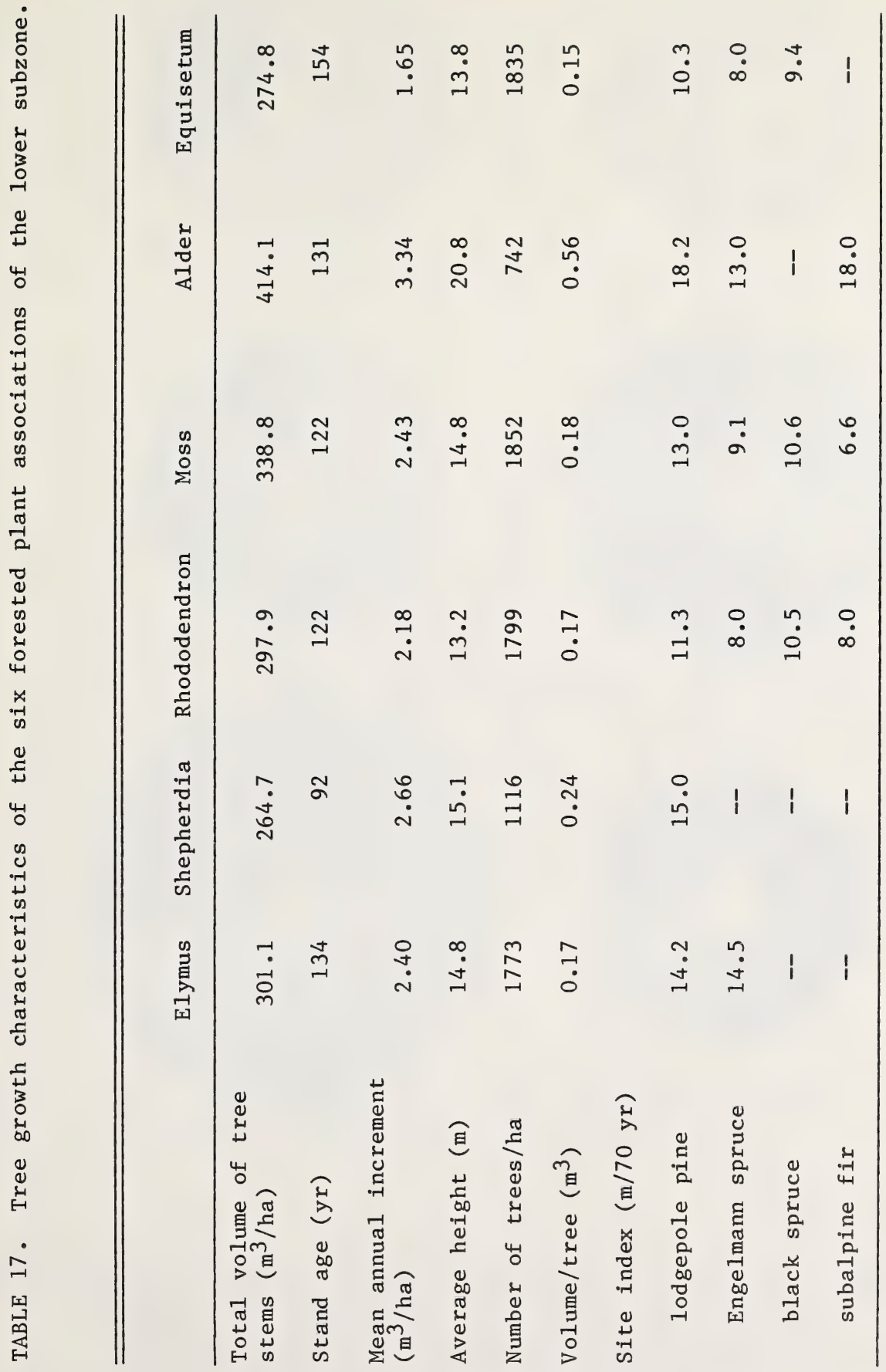




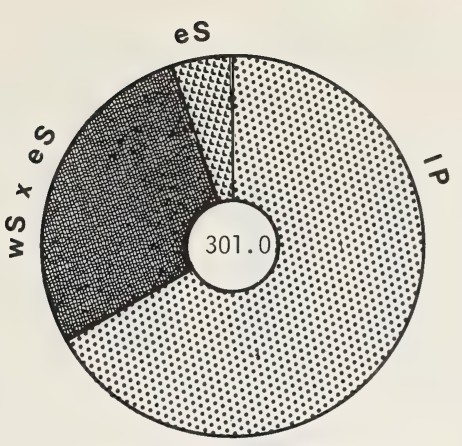

1. Pine - Elymus association

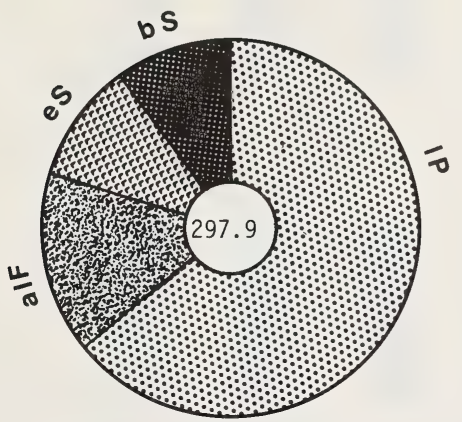

3. Pine - Rhododendron association

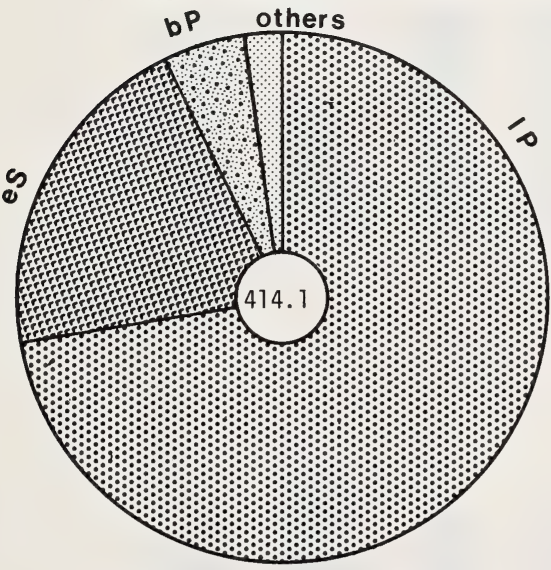

5. Pine - alder association

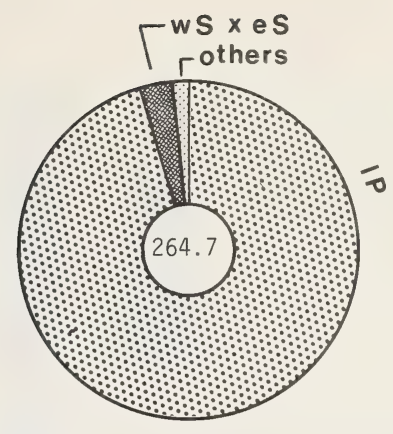

2. Pine - Shepherdia association

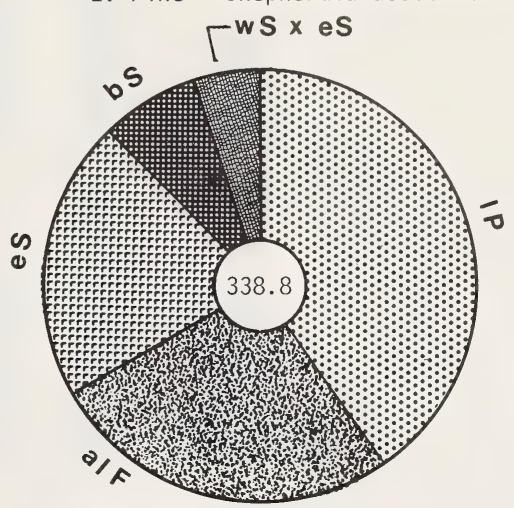

4. Spruce - moss association

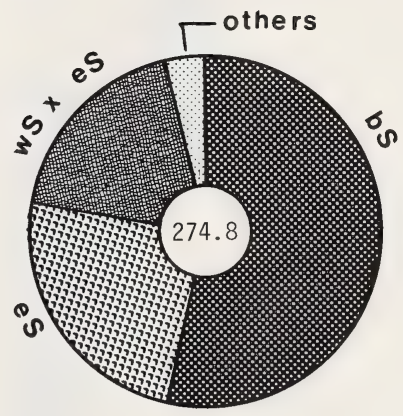

6. Spruce - willow - Equisetum association

Figure 49. Total volume of tree stems partitioned by species. Size of the circles is proportionate to the total volume $\left(\mathrm{m}^{3} / \mathrm{ha}\right)$ which is indicated in the centre of the circle (es, Engelmann spruce; wS $x$ eS, white spruce/Engelmann spruce hybrids; bS, black spruce; $1 \mathrm{P}$ lodgepole pine; alF, subalpine fir; bP balsam poplar) 

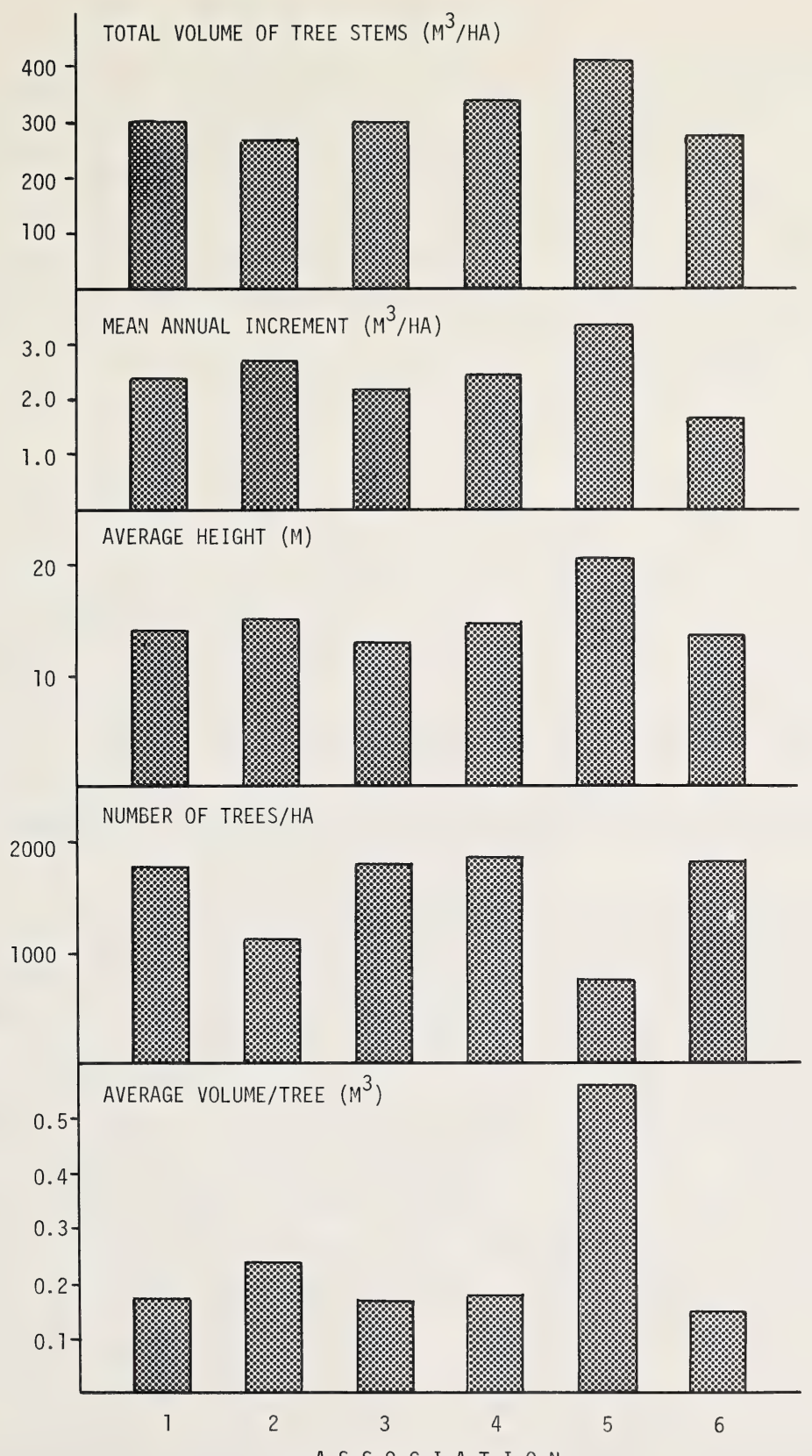

A S S O C I A T I O N

Figure 50. Tree growth characteristics of the six forested plant associations of the lower subzone. 1. Elymus association; 2. Shepherdia association;

3. Rhododendron association; 4. moss association;

5. alder association; and 6. Equisetum association 
Despite the high base status of soils in the Equisetum association, this association has a low forest productivity. It exhibits the lowest values for total stem volume per hectare, average height of trees, mean annual increment, average volume per tree, and site indices of lodgepole pine, Engelmann spruce and black spruce. Such a low productivity, despite the nutritionally rich habitat of this association, is likely a result of poor drainage of soils. Generally, trees are small and dense in this association.

The Elymus association supports good growth of Engelmann spruce, which attains its highest site index in this association. Growth of lodgepole pine is also relatively rapid in this association. The Shepherdia association is second in productivity based on mean annual increment and site index. In general, the Rhododendron association is rather low in productivity. It shows the second lowest mean annual increment, lowest average tree height, the second lowest average volume per tree, and a low site index for Engelmann spruce.

To explore which factors influence forest productivity, some selected soil factors were compared with the productivity of the six associations (Table 18). In the table, for the sake of simplicity, forest productivity and soil factors were rated qualitatively into three broad classes - high, medium and low. However, the bottom row of Table 18 indicates forest productivity of the association in approximate quantitative terms. The latter quantitative estimates were derived from summations of the three general classes of mensurational parameters in which 3 points were assigned for "high", 2 points for "medium", and 1 point for "low".

By this method, the alder association is highest in terms of productivity. Such a high productivity is promoted by the high amount of nitrogen that is provided by symbiotic nitrogen fixation by alder. This association is also favored by proper drainage of soils and an ample supply of basic cations. 


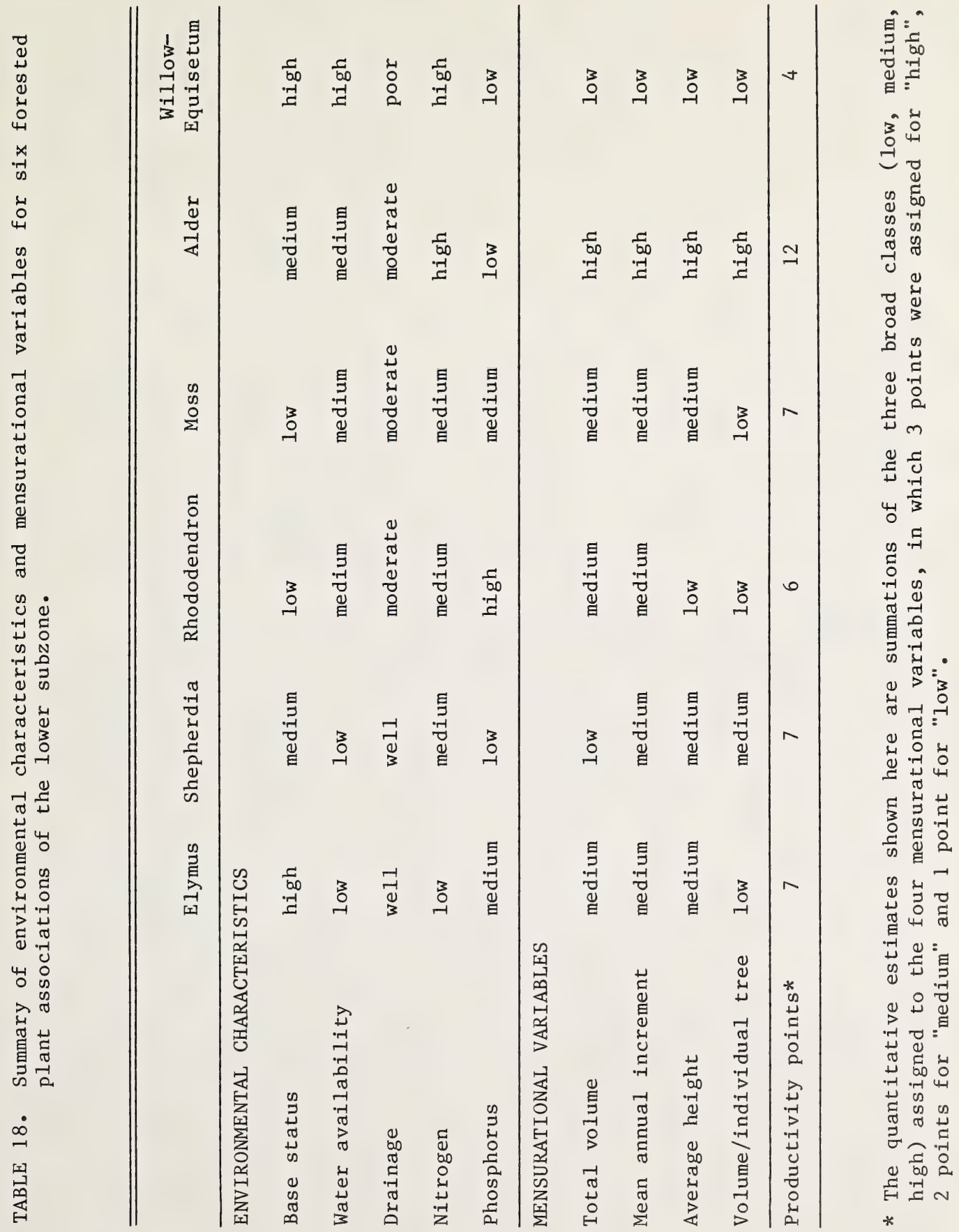



The Elymus, Shepherdia and moss associations are more or less in the same rank in terms of productivity. For the Elymus association, despite the high base status, low availability of water and nitrogen are thought to be the factors that result in relatively low forest productivity. In the case of the Shepherdia association, low water availability seems to limit forest production. The base status is slightly lower in the Shepherdia association than in the Elymus association, but the latter has a lower availability of nitrogen, with the net result that productivities in the two associations are similar. The moss association has a relatively good soil moisture availability which promotes forest production. However, base status of the soil in the moss association is low as a result of a relatively high rate of leaching, which tends to counteract the better moisture availability. Consequently, forest production in the moss association remains in an intermediate rank, comparable to the Shepherdia and Elymus associations.

\section{Although both the Rhododendron and Equisetum} associations are in the lowest classes of forest productivity, the circumstances of the two are quite different. In the case of the Rhododendron association, the low productivity appears to be a result of low base status of the soils. In fact, base saturation, as well as $\mathrm{pH}$, of the soils of this association are lowest of the six forested associations of the lower subzone. However, in the case of the Equisetum association, poor drainage is the limiting factor to forest production. This association shows a high base status as well as high nitrogen availability, both of which would ordinarily encourage high productivity. However, a lack of proper aeration in the rhizosphere appears to impede tree growth in the Equisetum association, despite other factors that seem to be favourable to growth. 



\section{SUMMARY AND CONCLUSIONS}

1. The first objective of this study was to establish a classification of forest ecosystems for the northern regions of the Engelmann spruce and subalpine fir biogeoclimatic zone of Alberta based on the biogeoclimatic ecosystem classification system. A second objective was to provide some basic information on the forested plant associations recognized in the area.

2. A total of eight forested plant associations were recognized in the study area. Of these, six associations represent forest ecosystems of the lower subzone of the subalpine zone, and two represent the upper subzone.

3. The eight forested associations were described in terms of vegetation structure, soil characteristics, and mensurational characteristics. Their edatopic characteristics were rated in terms of hygrotope and trophotope and their edatopic positions were projected on edatopic grid matrices.

4. Of the eight forested associations, the alder association was found to be the most productive in terms of tree growth.

5. Relationships between the plant associations and certain environmental characteristics were discussed and some factors that influence development of the plant associations were identified.

6. The development of ecologically sound forest management practices within the northern subalpine regions of Alberta can be aided by recognition of the eight different forested associations described in this report, both during office planning and field application. Forest management techniques should be designed to match the ecological and forest productivity differences of the eight associations. 

REFERENCES CITED

Black, C.A., D.D. Evans, J.L. White, L.E. Ensminger, F.E. Clark, and R.C. Dinaver, Editors. 1965. Methods of soil analysis. American Society of Agronomy Monograph No. 9, Madison, Wisconsin. 1572 p.

Braun-Blanquet, J. 1928. Pflanzensoziologie. Grundzüge der Vegetationskunde. Erste Auffl. Springer, Berlin. 330 p

Brooke, R.C., E.B. Peterson and V.J. Krajina. 1970. The Subalpine Mountain Hemlock zone. Ecology of Western North America $2(2): 148-349$

Canadian Soil Survey Committee. 1978. The Canadian system of soil classification. Canada Department of Agriculture. Publication 1646. Supply and Services Canada, Ottawa. 164 p

Dahl, E. 1956. Rondane: Mountain vegetation in south Norway and its relation to the environment. Norske Videnskaps-akademi, Os1o, Matematisk-naturvidenskapeleg klasse Skrifter 1956(3):1-374

Farley, A.L. 1979. Atlas of British Columbia. University of British Columbia Press, Vancouver. $136 \mathrm{p}$

Franklin, J.F. and C.T. Dyrness. 1969. Vegetation of Oregon and Washington. U.S.D.A., Forest Service, Pacific Forest and Range Experiment Station, Portland, Oregon. Research Paper PNW-80. $216 \mathrm{p}$

Greweling, T. and M. Peech. 1960. Determination of soil organic matter. Chemical soil test. Cornell University, Agricultural Experiment Station Bulletin 960:34-36

Hardy, W.G., Editor. 1967. Alberta: a natural history. M.G. Hurtig, Publishers, Edmonton. $343 \mathrm{p}$

Klinka, K. 1976. Ecosystem units, their classification, interpretation, and mapping in the University of British Columbia Research Forest. University of British Columbia, Vancouver. Ph.D. Thesis. $662 \mathrm{p}$

- 1977a. Guide for the tree species selection and prescribed burning in the Vancouver Forest District. Second approximation. Province of British Columbia, Ministry of Forests, Forest Service, Research Division, Vancouver Forest District, Vancouver. 42 p

1977b. Application of synecological classification in second growth management. IN: J.P. Kimmins, Editor, Ecological classification of forest land in Canada and northwestern U.S.A., Proceedings of a symposium sponsored by the Forest Ecology Working Group of Canadian Institute of Forestry and Centre for Continuing Education, University of British Columbia. Vancouver. p 19-23 

Klinka, K and R.E. Carter. 1980. Ecology and silviculture of the most productive ecosystems for growth of Douglas-fir in southwestern British Columbia. Province of British Columbia, Ministry of Forests, Victoria. $12 \mathrm{p}$

Klinka, K., F.C. Nuszdorfer and L. Skoda. 1979. Biogeoclimatic units of central and southern Vancouver Island. Province of British Columbia, Ministry of Forests, Victoria. 120 p +1 map

Klinka, K., W.D. van der Horst, F.C. Nuszdorfer and R.G. Harding • 1980. An ecosystematic approach to a subunit plan. Province of British Columbia, Ministry of Forests, Victoria. Land Management Report No. 5. $118 \mathrm{p}+1$ map

Klinka, K., M.C. Feller and L.E. Lowe. 1981. Characterization of the most productive ecosystems for growth of Pseudotsuga menziesii var. menziesii in southwestern British Columbia. Province of British Columbia, Ministry of Forests, Victoria. Supplement to Land Management Report No. 6. $49 \mathrm{p}$

Kojima, S. 1971. Phytogeocoenoses of the Coastal Western Hemlock Zone in Strathcona Provincial Park, British Columbia, Canada. University of British Columbia, Vancouver. Ph.D. Thesis. $322 \mathrm{p}$

1980. Biogeoclimatic zones of southwestern Alberta. Alberta Department of Energy and Natural Resources, Alberta Forest Service, Edmonton. $36 \mathrm{p}+$ appendices +1 map

1981. Biogeoclimatic ecosystem classification and its practical use in forestry. Journal of the College of Liberal Arts, Toyama University $14(1): 41-75$

Kojima S. and V.J. Krajina. 1975. Vegetation and environment of the Coastal Western Hemlock Zone in Strathcona Provincial Park, British Columbia, Canada. Syesis 8, Supplement 1:1-123

Kojima S. and G.J. Krumlik. 1977. Biogeoclimatic ecosystem classification of Alberta. Fisheries and Environment Canada, Canadian Forestry Service, Northern Forest Research Centre, Edmonton, Alberta. Progress report for project NOR-27-169. $10 \mathrm{p}$

1979a. Biogeoclimatic zones of Alberta, Canada. Paper presented at the $26 \mathrm{th}$ annual meeting of the Ecological Society of Japan, Apri1, 1979, Yokohama, Japan.

1979b. Biogeoclimatic classification of forests in Alberta. Forestry Chronicle 55(4):130-132

- 1980. Biogeoclimatic zones of southwestern Alberta. Paper presented at the BOTANY 80 conference, Vancouver. July, 1980.

Krajina, V.J. 1959. Bioclimatic zones in British Columbia. University of British Columbia, Botanical Series 1:1-47 

1960. Can we find a common platform for the different schools of forest type classification? Sylva Fennica 105:50-55

- 1965. Biogeoclimatic zones and biogeocoenoses of British Columbia. Ecology of Western North America 1:1-17

1969. Ecology of forest trees in British Columbia. Ecology of Western North America 2(1):1-147

- 1972. Ecosystem perspective in forestry. H.R. MacMillan Forestry Lecture Series, University of British Columbia, Vancouver. $31 \mathrm{p}$

- 1973. Biogeoclimatic zones of British Columbia. British Columbia Department of Lands, Forests, and Water Resources, Ecological Reserves Committee, Victoria. Map (Scale 1:1,900,800)

1975. Some observations on the three subalpine biogeoclimatic zones in British Columbia, Yukon and Mackenzie District. Phytocoenologia 2:396-400

Krumlik, G.J. and J.D. Johnson. 1978. Biogeoclimatic ecosystem classification of Alberta. Fisheries and Environment Canada, Canadian Forestry Service, Northern Forest Research Centre, Edmonton. Progress report for project NOR-27-169. $7 \mathrm{p}$

Krumlik, G.J., J.D. Johnson and L.D. Lemmen. 1978. Biogeoclimatic ecosystem classification of Alberta. Forest types in northwestern Alberta - first approximation. Fisheries and Environment Canada, Canadian Forestry Service, Northern Forest Research Centre, Edmonton. $104 \mathrm{p}$

- 1979. Biogeoclimatic ecosystem classification of Alberta progress report for $1978 / 79$ fiscal year. Fisheries and Environment Canada, Canadian Forestry Services, Northern Forest Research Centre, Edmonton. 220 p

Kuichler, A.W. 1964. Potential natural vegetation of the conterminous United States. American Geographical Society, Special Publication 36. $38+116$ p +1 map

North, M.E.A. 1976. A plant geography of Alberta. An interpretation based on the 1965 vegetation map. University of Alberta, Department of Geography, Edmonton. Studies in Geography Monograph 2. $147 \mathrm{p}+1$ map

Northern Forest Research Centre. 1977. Study statements 1977-1978. Fisheries and Environment Canada, Canadian Forestry Service, Northern Forest Research Centre, Edmonton. p 436-439 

Pfister, R.D., B.N. Kovalchik, S.F. Arno, and R.C. Presby. 1977. Forest habitat types of Montana. U.S.D.A., Forest Service, Intermountain Region, Ogden, Utah. General Technical Report INT-34. $174 \mathrm{p}$

Pogrebniak, P.S. 1930. Über die Methodik von Standortsuntersuchungen in Verbindung mit Waldtypen. Verh. II. Intern. Congr. Forstl. Versuchsanstalten, 1929. Stockholm.

Rowe, J.S. 1972. Forest regions of Canada. Department of Fisheries and the Environment, Canadian Forestry Service, Ottawa. Publication No. 1300. $172 \mathrm{p}+1$ map

Rutter, N.W. 1972. Geomorphology and multiple glaciation in the area of Banff, Alberta. Geological Survey of Canada, Ottawa. Bulletin 206. $54 \mathrm{p}$

Sibirtzev, N.M. 1898. Outline of the main soil types of Russia. (Kratkii obsor-glavneishikh pochvennykh tipov Rossii). Zapiski Novo-Aleksandrievskogo Into. Vol. II. $538 \mathrm{p}$

Sørensen, T. 1948. A method of establishing groups of equal amplitude in plant sociology based on similarity of species content and its application to analysis of the vegetation on Danish commors. K. Danske Videnskabernes Selskab Biologiske Skrifter $5(4): 3-16,34$

Sukachev, V.N. 1958. (On the principles of genetic classification in biocoenology). Condensed English translation by F. Raney and R.F. Daubenmire of "0 principi geneticeskoj klassifikacii $\frac{\mathrm{v}}{2}$ biocenologii". Zhurnal Obshchei Biologii 5: $\overline{213-277 . \quad(1944)}$ Ecology 39:364-367

Sukachev, V.N. and N. Dylis, Editors. 1964. Fundamentals of forest biogeocoenology. English translation by Oliver and Boyd Ltd., Edinburgh and London. $672 \mathrm{p}$

Tansley, A.G. 1935. The use and abuse of vegetational concepts and terms. Ecology 16:284-307

Thornthwaite, C.W. 1948. An approach toward a rational classification of climate. Geographical Review 38:55-94

Trewartha, G.T. 1957. Elements of physical geography. McGraw-Hill Book Co. New York.

1968. An introduction to climate. Fourth edition. McGraw- Hill Book Co., New York. 408 p

Twardy, A.G. and I.G.W. Corns. 1980. Soil survey and interpretation of the Wapiti Map Area, Alberta. Alberta Research Council, Alberta Institute of Pedology, Edmonton. Bulletin $39.134 \mathrm{p}+4$ maps 

Walker, B.D., S. Kojima, W.D. Holland, and G.M. Coen. 1978. Land classification of the Lake Louise Study Area, Banff National Park. Fisheries and Environment Canada, Canadian Forestry Service, Northern Forest Research Centre, Edmonton. Information Report NOR-X-160. $121 \mathrm{pp}+1$ map.

Watanabe, F.S. and S.R. 01sen. 1965. Test of an ascorbic acid method for determining phosphorus in water and $\mathrm{NaHCO}_{3}$ extracts from soil. Soil Science Society of America, Proceedings 29:677-678 


33286065992444 